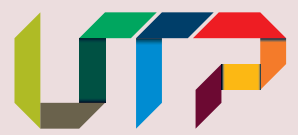

Universidad Tecnológica de Pereira

Facultad de Bellas Artes y Humanidades

\title{
Conciencia histórica y diálogo de tradiciones en La otra raya del tigre de Pedro Gómez Valderrama
}

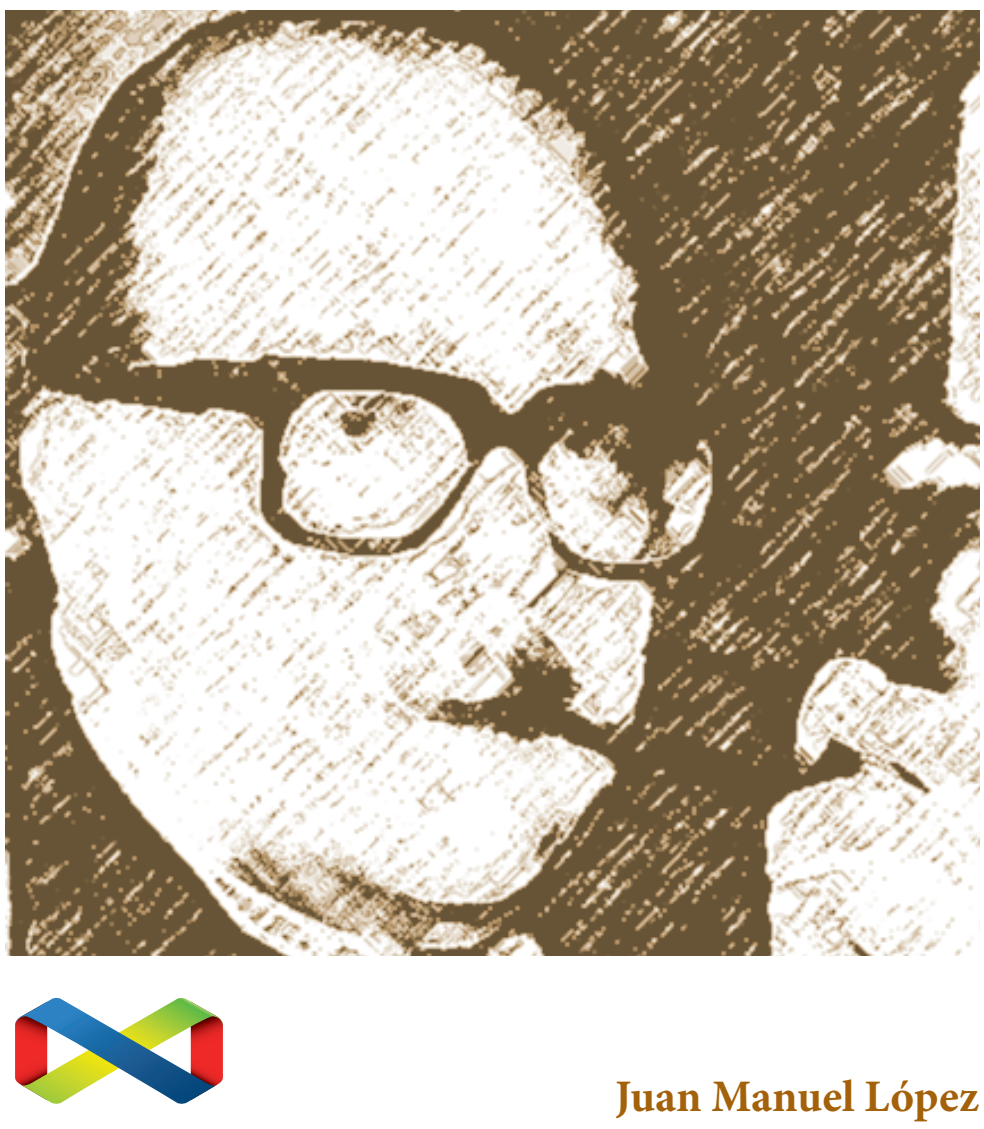

Editorial UTP 


\section{Conciencia histórica y diálogo de}

\section{tradiciones en La otra raya del tigre de}

Pedro Gómez Valderrama

Juan Manuel López

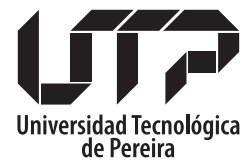

Colección Ensayos

Facultad de Bellas Artes y Humanidades

Maestría en Literatura 
López, Juan Manuel

Conciencia histórica y diálogo de tradiciones en la otra raya del tigre de Pedro Gómez Valderrama / Juan Manuel López. - Pereira :

Editorial Universidad Tecnológica de Pereira, 2017.

104 páginas : ilustrado. -- (Colección Ensayos).

ISBN: 978-958-722-282-1

1. Literatura colombiana 2. Gómez Valderrama, Pedro, 1923-1992

3. Crítica textual 4. Novela histórica colombiana 5. Lenguaje y lenguas

CDD. 863.6

Conciencia histórica y diálogo de tradiciones en La otra raya del tigre de Pedro Gómez Valderrama

(C) Juan Manuel López

(C) Universidad Tecnológica de Pereira

Primera edición e-book, 2017

\section{Universidad Tecnológica de Pereira}

Vicerrectoría de Investigaciones, Innovación y Extensión

Editorial Universidad Tecnológica de Pereira

\section{Coordinador editorial UTP}

Luis Miguel Vargas Valencia

luismvargas@utp.edu.co

Tel:3137381

Edificio 9, Biblioteca Central "Jorge Roa Martínez" 9/N1/110

Cra. 27 No. 10-02 Los Álamos

Pereira, Colombia

www.utp.edu.co

\section{Montaje y producción:}

Universidad Tecnológica de Pereira

Centro Recursos Informáticos y Educativos, CRIE

\section{Reservados todos los derechos}


Índice

Agradecimientos

Introdución $\quad 7$

Conciencia histórica 12

Diálogo de tradiciones 17

Capítulo I:

Apuntes para la comprensión del concepto de novela histórica $\quad 25$

Un acercamiento al término "novela" 27

Reflexiones en torno a la palabra "historia" 30

Sobre la novela histórica $\quad 34$

Objeto de la novela histórica $\quad 37$

Relación con la verdad de hecho $\quad 40$

Capítulo II:

Apuntes para la comprensión del concepto $\quad 48$

de nueva novela histórica

Objeto de la nueva novela histórica $\quad 52$

Relación con la verdad de hecho $\quad 54$

Capítulo III:

Consideraciones en torno a algunos apartes de la obra de

Pedro Gómez Valderrama y La otra raya del tigre $\quad 60$

Apuntes preliminares sobre la otra raya del tigre $\quad 62$

El cortejo a la nueva novela histórica $\quad 69$

Capítulo IV:

El abuelo, y Lengerke, un diálogo entre lo propio y lo occidental 80

El abuelo, una tradición sumamente propia 83

Geo von Lengerke, la mirada de Occidente $\quad 89$

Conclusión $\quad 94$

Bibliografía $\quad 98$

Índice onomástico 103

Índice analítico 104 


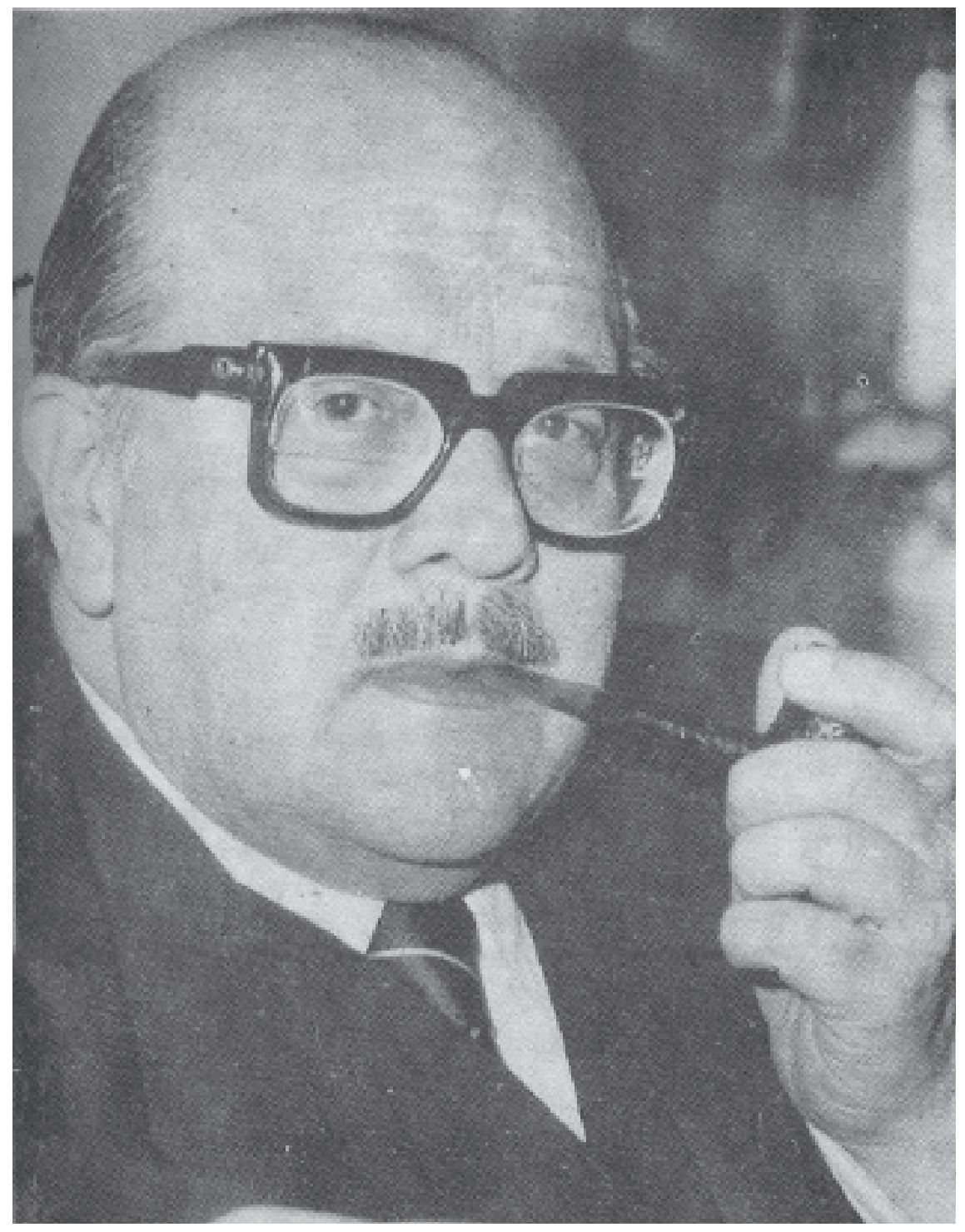

Imagen tomada del libro de Jorge Eliécer Ruiz, Antología de Pedro Gómez Valderrama $(1995 ; 17)$ 


\section{Agradecimientos}

No se puede permanecer tanto tiempo en este universo de signos, indicios y símbolos que configuran el pensamiento sin contraer insondables deudas. Este aparte que conforma a manera de signo un instante de lo no dicho en este transcurso de mis reflexiones en torno a Pedro Gómez Valderrama y, en especial, a su novela, La otra raya del tigre (1977), pretende retribuir en una mínima parte, con una escueta alusión, lo que muchas existencias me han confinado. El esfuerzo para elaborar las reflexiones que ahora se presentan oficialmente no hubiera sido posible sin el constante apoyo de los profesores de mi Escuela de Filosofía. En primer lugar debo mencionar al doctor Carlos Eduardo Peláez, quien generosamente en la charla de una cafetería que hoy ya no existe, fue quien me llevó a conocer "indirectamente" al escritor para hacer la presente indagación. Mi gratitud con él, el director de este proyecto, es semejante a lo que el primer escritor de filosofía griega pudo denominar en su propia lengua apeiron, puesto que parejo al ejercicio académico Carlos ha sido el arquetipo. Debo mucho a nuestro actual director de la Escuela, el profesor Luis Guillermo Quijano y al cuerpo de docentes que conforman su comité curricular por haberme facilitado el ocio, condición formal necesaria en la escritura, a fin de darle el último impulso a esta senda de signos que configuran el texto que ahora se lee. Ellos, al ajustar mi carga académica en los dos últimos semestres han sido la mano oculta que ha contribuido a que culminara el camino que emprendí de la mano de Pedro Gómez Valderrama hace ya casi tres años.

No puedo dejar de mencionar a mis profesores y compañeros de la Maestría en Literatura. Este conjunto de personas, más que nadie, debieron tolerar haber compartido este camino del conocimiento con una presencia inquieta que ve en los contenidos de la cultura una forma honesta de poder entablar una conversación con el otro. Es fundamental expresar mi gratitud al profesor César Valencia Solanilla quien estando a cargo de la dirección de la Maestría en Literatura pudo darme el espacio necesario para culminar a bien unos estudios que a falta de suficiencia económica debieron quedar interrumpidos en el rigor académico por un año. A los profesores Arbey Atehortúa y Rodrigo Arguello y los demás jurados que revisaron el texto e hicieron anotaciones sobre el mismo. Ellos con sus anotaciones sobre la impertinencia de algunos pasajes del texto contribuyeron a darle una mayor claridad al mismo y, con ello, darle una mayor solidez a la forma de expresarme en relación a 
la manera de abordar el problema que planteo en la única novela publicada de Pedro Gómez Valderrama.

Finalmente, no podía dejar de incluir en este apartado el infinito agradecimiento con alguien ya lejano, distante de cuerpo en su solitario mausoleo, José Eliécer López. Su presencia, anterior por la generación y la historia a la mía, ha dejado, como también en otra dimensión de la memoria se le dejó a Sofía Amundsen, un cúmulo de migajas de pan mimetizadas en páginas de libros a lo largo de mi camino como elección de vida. Esas hojas de papel fueron conducentes a descubrir ese regalo que me ayudaría a crecer y que me ha de acompañar hasta el instante que a la agonía sucede.

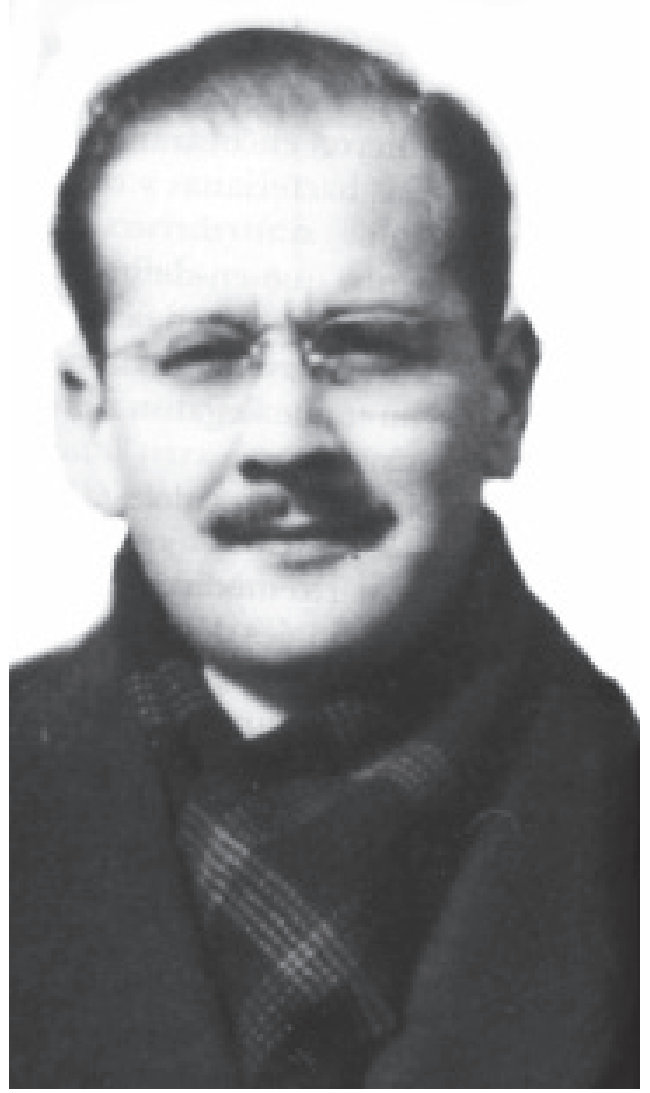

Imagen tomada de la Revista de la Universidad de Antioquia

(2006; Abril-Junio) Número 284, p. 46 


\title{
Conciencia histórica y diálogo de tradiciones en La otra raya del tigre de Pedro Gómez Valderrama
}

\author{
"El estudio de otros géneros es parecido al de las lenguas muertas; \\ y el estudio de la novela es similar al de las lenguas vivas $y$, \\ además, jóvenes”.
}

Bajtín

\section{Introducción}

Esta palabra, introducción, como puede apreciarse, se encuentra situada en una propuesta escrita y, entonces, comprendida ella como apartado de un texto, debe ser asumida como un instante, una “arandela” teórica en esa acción de conducirnos hacia adentro que conforma su significado etimológico. Ella, la introducción, en armonía con lo ya dicho, debe suscitar una seducción o simplemente establecerse como un recurso pedagógico que haga más amable el tránsito desde afuera hacia donde se le quiere conducir al lector: hacia adentro. Hallamos así que es necesario en el primero de los casos, en el de tomar la introducción como seducción, un presupuesto básico. Conocer el gusto del lector. Esta empresa es notablemente imposible para un aprendiz en el ejercicio de la escritura, por dos razones esenciales; la primera de ellas es que nuestro texto constituye un esfuerzo por elaborar una crítica literaria sobre una obra particular de nuestra literatura: La otra raya del tigre y, como todo esfuerzo de este tipo el lenguaje que se ha de emplear en él, procura ser sensiblemente claro, sin mayores pretensiones que la de exponer una idea de forma entendible. Así podemos prever que el texto ha de carecer de un lenguaje intrincado al tiempo que seductor ${ }^{1}$.

\footnotetext{
1. Ello en la medida en que en este ir de camino que es el conocimiento, del cual este ejercicio escrito es un breve trozo. La posesión de dicho conocimiento que se muestre a través de un lenguaje seductor e intrincado a favor de esclarecer una idea dista de lo que podamos hacer; es por lo pronto este ejercicio literario más una práctica en pro de la adquisición de un conocimiento, es un rendir cuenta de, y como en todo esfuerzo hay en él falencias que solo son posibles subsanarlas a través de una práctica continua, neurótica si se quiere, de este fatal arte de escribir.
} 
Descartada la primera vía para elaborar una intro-duc-ción, la del camino seductor del lector hacia el interior del tema a través de un lenguaje encantador, ésta que ahora se presenta no puede más que intentar un recurso pedagógico. Pedagógico aquí, como puede verse, se utiliza como un adjetivo al acompañar a la palabra recurso, recalcado ello por el morfema ico que compone la palabra, lo cual nos señala, en su configuración, que hay una especificación del sustantivo que le precede. Pedagógico quiere decir aquí, lo que señala la palabra en su comienzo, en la escritura del griego antiguo paidagogía (Pedagogía). Ella indica la acción de guiar (ago) al niño (país). Esta referencia al comienzo de la palabra pedagógico nos hace pensar en el origen de la misma, en la situación que le dio el impulso inicial a la palabra, es decir, en la conducción o acompañamiento de aquel que carece de conocimiento (el niño es un bello signo para perseguir esta idea).

Por esta vía, el camino pedagógico, no podemos señalar gran cosa. Nuestro conocimiento se reduce al haber permanecido en la compañía de dos o tres libros. Aquí, en las páginas que vienen de este ejercicio, se hallarán referencias explícitas a la producción escrita de Pedro Gómez Valderrama, sobre manera a su novela, $L a$ otra raya del tigre (1977), esporádicamente a sus Invenciones y artificios, de forma irregular a sus demoníacas Muestras del diablo, y de una manera casi incidental a Los ojos del burgués. También se hallarán un conjunto de referencias a algunas entrevistas y prólogos de libros. La cercanía desarrollada en algunos meses con el autor, el contacto "indirecto" a través de su escritura y las referencias encontradas en ella, que en conjunto conforman la imagen del literato, es lo que bien pudiera mostrarse aquí como aquello que el otro, usted señor lector, ignora del asunto y que mínimamente cumple con un requisito indispensable en el ejercicio de la educación, querer saber. De tal suerte, esta intro-duc-ción asumida como recurso pedagógico resulta ser algo frágil, tal como lo es la naturaleza del conocimiento que en este lugar se pretende comunicar.

El relato que aquí se teje es, como la palabra latina lo indica, una referencia a la obra de Gómez Valderrama. Nuestra referencia indica que hay un volver a llevar, (relato) una vuelta hacia la ignota escritura (cultura) de quien no conoce al autor que hemos tomado para construir nuestro discurso; hemos vuelto hacia alguien que ha quedado atrás, cubierto por el tiempo y la palabra, por las letras, por los escritores de moda, por los que ahora se leen; un ejercicio de escritura que no es sólo ello en tanto que procura el desvelamiento de un contenido a la luz del conocimiento es, como todo ejercicio de este tipo, una denuncia, un sacar de la sombra, un revivir al escritor de La otra raya del tigre. Pero esta aventura de unir dos mundos, dos regiones del saber que mutuamente se reclaman, la de lo no sabido y lo conocido, no es posible más que al crisol de los grafemas de la escritura, es decir, por medio de la elaboración de un texto, de un relato. 
Nuestro relato ha de tener como pre-texto una intrincada forma de acaparar la lectura de una obra, precisamente de un ejercicio literario específico: La otra raya del tigre. Inventamos ${ }^{2}$ para mostrar nuestro ejercicio de lectura sobre el texto mencionado, una compleja red conceptual para conducirnos en ese terreno donde las imágenes hechas con palabras, matices, significados, figuras literarias, indicios; superabunda. Dos términos esenciales que procuramos entretejer en el presente ejercicio son nuestro baremo para evitar así el extravío al que nos vemos avocados cuando la imagen que se teje con palabras escritas, de la cual hace gala la asombrosa literatura (cfr. Bajtín, 1991; 13-75), resulta ser nuestro campo de acción. Ellos, los términos ya mencionados, otorgan un sentido que propende por la rigurosidad: conciencia histórica y diálogo de tradiciones. A través de su esquemática definición en lo que viene de este apartado intentaremos dar a entender una tesis bastante particular en todas su implicaciones: la obra de Pedro Gómez Valderrama antes mencionada, La otra raya del tigre, constituye un muy fino llamado hacia aquello que tenemos de auténtico, aquello que es profundamente propio.

Se pretende demostrar en este análisis que la novela La otra raya del tigre, es una narración que bien puede identificarse con la novela histórica en el sentido clásico de la expresión. Así pues, en el texto que ahora el lector tiene en frente, se encontrará una contraposición entre dos conceptos que son potestativos del análisis literario como lo son el de la novela histórica y la nueva novela histórica. Nuestra reflexión demostrará haciendo presente una serie de elementos puestos en la novela que, precisamente, La otra raya del tigre hace parte del primer género y no del segundo, debido esto a que la novela presenta unas particularidades que la identifican como vinculada a tal género literario; y lo hace en la medida en que encontrarse con la literatura de Gómez Valderrama, al menos en esta, su única novela, es hallarse de frente con la historia, con lo sido por el hombre antes de acontecer como portador de esa insignia, heráldica si se quiere, que es lo pensado en el tiempo atestiguado por la escritura: la cultura.

Entre los términos que se definirán en el presente apartado, como ya lo señalamos, tenemos el de conciencia histórica y diálogo de tradiciones. Con ello esperamos dejar abonado el terreno para, luego, de una manera sumamente ulterior, involucrar nuestro objeto de estudio, la novela antes mencionada de Pedro Gómez Valderrama, con un determinado género novelístico. Claro está, ello debe hacerse exponiendo previamente en qué consiste cada uno, y así, de forma posterior, definir con evidencias a qué género pertenece $y$, sobre todo, con qué $\mathrm{fin}^{3}$. Después de la

2. Tómese la palabra en su sentido prístino, latino: encontrar.

3. Algunos trabajos de la Maestría en Literatura que abordan este problema de la relación entre el género y los con- 
clasificación de los géneros literarios y de hacer un breve comentario sobre la obra de Gómez Valderrama buscaremos algunos elementos que nos permitan diferenciar el diálogo entre nuestra tradición y la tradición occidental; para este último paso, que constituye en propiedad el análisis, proponemos una variación a una categoría de análisis literario ya existente que puede vincularse con el procedimiento de la psicocrítica.

En esta dirección nuestra tesis ha tenido a bien llamarse Conciencia histórica y diálogo de tradiciones en La otra raya del tigre de Pedro Gómez Valderrama y nuestra hipo-tesis a demostrar no puede ser otra más que la que ya hemos señalado: en esta obra hay una preocupación por la cimentación de una cultura propia, de un llamado hacia la conciencia histórica de una manera muy peculiar. Con ello se establece que aquello que acontece en la obra de Gómez Valderrama no es otra cosa que el hecho de formar una conciencia de lo propio a través de un diálogo de tradiciones que se hace evidente desde el inicio de la obra misma.

Así mostrado nuestro propósito, que no deja de ser complejo, debemos advertir que las indagaciones llevadas a cabo por quienes tomamos el riesgo, pero sobre todo la seria responsabilidad de asumir las riendas de ese discurso que pertenece al campo de la estética y que, al unísono, colinda con el de las humanidades, no pueden estas, las indagaciones en cuestión, más que tener un punto inicial para entregarse a la elaboración: el ejercicio casi enfermizo por la solución a una neurótica pregunta ${ }^{4}$. En esta situación del ejercicio escrito en general, que es también nuestro punto de partida, tomamos como lugar de referencia el siguiente cuestionamiento: ¿Qué es lo que tenemos de propio? La pregunta entonces, así formulada, al inquirir con el pronombre interrogativo qué, hace gala de nuestro exclusivo preguntar por lo sustancial de un asunto, por aquello que no admite variabilidad y también, en una sola expresión, por eso otro que es fundamentalmente nuestro, lo propio.

tenidos que el escritor deposita en sus textos son: Porchia: el íntimo desvarío de la certeza (2008). Ed. Universidad Tecnológica de Pereira, escrito por Rodolfo Cabrales; Pensar lo implícito. En torno a Gómez Dávila (2008) Ed. Postergraf, Pereira, escrito por el profesor Alfredo Andrés Abad. Hay que señalar que estos trabajos insisten en la relación entre la escritura fragmentaria y el talante escéptico de cada uno de los escritores. Aquí se avanza en otra dirección diferente, al considerar lo que hay de implícito en la literatura de Gómez Valderrama al escoger, no gratuitamente, este género de la novela histórica para elaborar su texto La otra raya del tigre.

4. A propósito de esta cuestión en la elaboración de las humanidades y en general del conocimiento, véase el texto del autodidacta Estanislao Zuleta en donde se señala, conforme al tema, lo siguiente. "una pregunta abierta es una búsqueda en marcha que tiene un efecto específico sobre la lectura. Sólo se sabe escribir para escritores, y sólo el que escribe realmente lee" (2001; 107). De tal suerte, así entendido el ejercicio originario del pensamiento, es menester una duda que oriente la lectura, en nuestra situación específica es la preocupación por mostrar que hay un diálogo de tradiciones en la obra de Pedro Gómez Valderrama, un diálogo que apunta hacia un sentido específico, de una manera particular. 
De esta suerte podría aseverarse que nuestra pregunta es tanto filosófica como literaria. Al preguntarnos por aquello que no admite el cambio, lo esencial ${ }^{5}$, podríamos estar hablando en lo que se conoce como una jerga meta-física, si es que en realidad esta, la jerga en cuestión, más que ser el complejo lenguaje de unos pensadores románticamente enclaustrados en su torre de marfil, no se encuentra también difuminada en el uso cotidiano. No obstante, lejos de todo prejuicio de algún sector de la filosofía contemporánea, al preguntar por lo que tenemos de propio simplemente inquirimos en pro de tener contacto con lo esencial, es decir, lo que no admite cambio en medio del devenir de aquello que sea, aún no sabemos con certeza, lo propio.

Empero, no solo teniendo un punto inicial a partir del cual nos entreguemos a la elaboración de una indagación, tenemos el camino dado. Es necesario trazarnos una senda, un método, un camino por el cual deba transitar nuestro pensamiento para llegar a un terreno firme. Para poder indagar qué es eso que tenemos de fundamentalmente propio, es necesario, en una primera instancia, señalar algunas indicaciones sobre las definiciones triviales de aquello que sea en rigor lo propio, después buscaremos aquello que fundamente una conciencia de lo que en realidad sea lo propio. Al hacer tal rastreo, y hallar el asunto de lo propio, estableceremos una relación con el termino historia y, finalmente entenderemos qué es eso de conciencia histórica en relación al término diálogo de tradiciones.

Como puede observarse es necesario que toda la indagación realizada aquí nos conduzca a aclarar también qué se entiende por el término diálogo de tradiciones. Para buscar la solidez de la definición de tal término, hemos de emplear una forma eminentemente etimológica de proceder matizando las palabras con significados entregados tanto por la teoría literaria como por las reflexiones filosóficas. Apegados al sentido prístino de las palabras hallaremos, al tiempo, la solidez que buscamos en el ejercicio de limitar el alcance de los términos que nos han de servir como derroteros al momento de ejecutar nuestra reflexión.

\footnotetext{
5. La palabra esencial puede descomponerse etimológica y morfológicamente para que su sentido sea aquí aclarado. La palabra proviene de la lengua latina, a saber la palabra essentia, se compone de dos partes: el verbo ser en su traducción latina del modo infinitivo, esse, y la palabra entis (genitivo de ens), la cual nos señala algo de los seres o las cosas existentes; de tal suerte la palabra en su traducción literal, un poco más compleja, habría de ser el ser del ente, es decir, lo sustancial que caracteriza para nosotros una cosa determinada. Así entendida, la palabra esencia, constitutiva del adjetivo esencial, designa lo que realmente importa del objeto cuando este nos aparece. La relevancia de lo esencial en la configuración particular de mundo puede rastrearse en un texto juvenil de Jaspers (Cfr. 1967; 24).
} 


\section{Conciencia histórica}

En primer lugar, como ya lo habíamos sostenido, indicaremos algunas definiciones acerca de lo propio en la más baladí de las direcciones. Debemos cuestionarnos si, en efecto, lejos de la mera apelación al sentimentalismo, recurrente en los actuales movimientos nacionalistas, los cuales pretenden hacernos retornar a un apego hacia una valoración de lo propio, exista en verdad, tras o en ello mismo, una conciencia de algo que sea, sin temor alguno, lo propio. Nuestro preguntar estará, así signado, enfocado a descubrir aquel dispositivo que detona en nosotros un sentido de pertenencia, algo que consideremos profundamente propio y que, sin más, sirva como detonante fundamental de ese amor por lo que tenemos de singular, ajeno a todo movimiento novedoso, esnobista, que también pretenda hacerlo, siendo este bien precario al momento de dar cuenta sobre una conciencia acerca de lo que tenemos propiamente de peculiar.

En verdad lo que denominamos en este lugar lo propio, ligado a lo que forma en nosotros ese sentido de ser pertenecientes a algo único, existe y persiste en el tiempo. No obstante a ello, vulgarmente lo propio se ha comprendido como objeto y desde este lugar, desde el tópico de lo objetual, es que toman forma las acepciones actuales que inundan los mass media, las cuales pretenden señalarnos la existencia de algo único en nuestra región. Es decir que aquello que se considera en este lugar de nuestra reflexión como lo propio, pese a darse en un tiempo determinado, se considera tal, vulgarmente, en el impulso fáctico de nuestra corporalidad, ante aquello que nuestro objeto inmediato de percepción, el cuerpo, puede captar de esa inmensa frontera espacial que conforma nuestro entorno; aquello que denominamos en este lugar lo propio estaría, así concebido de una manera material, al poder nosotros decir que esto o aquello otro, diseminado en la frontera de la espacialidad, es, sin más ni más, lo nuestro. Ello, si bien lo pensamos al estar señalado con los pronombres demostrativos antes signados, esto o aquello, se podría predicar de una región particular, con toda la amalgama posible de encontrar en ella, referida esta mezcla perfecta a su variopinta pluralidad silvestre. En tal región, a su vez, podríamos hallar una pluralidad de seres vivientes e inertes que conforman dicha zona geográfica $y$, añadido a ella, y tal vez como resultado de esta exuberancia que nos entrega el medio geográfico, la variedad de sus frutos que, de igual manera, son víctimas de unas condiciones territoriales particulares; este conglomerado de factores constituyen un claro ejemplo de aquello que consideramos, sin más ni más, de una forma muy baladí, algo fundamentalmente propio.

Quizás otra de las posibles maneras de manifestarse en realidad la existencia de una conciencia de lo propio, además de estar referida ésta a lo objetualmente 
único que poseemos, sea buscando un amparo en el marco intelectual que nos ha legado el Romanticismo. Este, como nos lo ha mostrado el transcurso del tiempo que se cifra en las letras, en los nombres, en las fechas, en las ideas, nos lleva a la construcción de un nacionalismo e, incluso, en nuestro país, a la conformación de determinados sentidos de pertenencia territoriales, más conocidos con el nombre de regionalismos. Ello, el surgimiento de un regionalismo, puede encontrarse incluso en las obras literarias como bien lo atestigua Menton (Cfr, 1978; 53) ejemplificado en una novela de Tomás Carrasquilla: Frutos de mi tierra (Ibíd; 132-134). Los regionalismos son asumidos como una manifestación orgullosa, casi egocéntrica de lo propio en confrontación con lo otro, con lo diferente, de una manera un poco gregaria: acentuando el rechazo de la alteridad para hacer una manifestación plena de lo autóctono ${ }^{6}$, sin detenerse tan siquiera un momento para apreciar la diferencia con lo otro.

No obstante, pese a que tales regionalismos han fraguado una ardua trama que toca incluso al universo de la literatura, parece que se le ha pasado su fecha de caducidad. Menton anota:

En Colombia, la incorporación socioeconómica de la región de la costa a la nación y el crecimiento vertiginoso de Bogotá ha puesto fin al regionalismo tradicional. A partir de la década del 60 , no cabe duda de que Bogotá es el único centro cultural del país a donde acuden novelistas de todas partes $(1993 ; 393-4)$.

Empero, pese a lo consignado por Menton, el regionalismo supervive ${ }^{7}$. Este rechazo de lo otro es aquello que ha hecho, sin lugar a dudas, que tales tipos de movimientos, los regionalismos, en pro de buscar una universalización de sus prejuicios particulares, contrario a tener éxito, hayan caído en el descrédito. En relación a lo antes dicho Peter Elmore apunta lo siguiente:

\footnotetext{
6. La palabra autóctono se halla aquí entendida en su sentido inicial al comienzo de la escritura en Occidente. Ella, tal y como lo puede anotar su transliteración en la lengua española se encuentra compuesta de dos partes, el pronombre demostrativo griego autos, cuya traducción reza el mismo o lo mismo, pero que también se puede entender como lo propio, y la palabra griega (chtonós) (debemos señalar que la palabra se encuentra tomada del caso genitivo, correspondiente al número singular de la lengua griega), cuya traducción es tierra. Así pues la traducción de la palabra en una forma estrictamente gramatical es lo propio de la tierra, en este sentido, entendido ello, lo propio, como lo que podemos observar en un aquí determinado.

7. Para observar la pervivencia de tal regionalismo obsérvese el reciente libro de César Valencia Solanilla (2008). Allí anota el autor, parece que los regionalismos han seguido su marcha en la literatura (Cfr. Ibíd; 9-13); empero, cabe anotar que hay un matiz que hace de la indagación del problema algo diferente: el asumir los regionalismos como periferia y el centralismo como canon.
} 
El tópico de la identidad nacional - que ha conocido usos radicales y conservadores a lo largo del siglo- resulta mucho menos seductor que en las décadas del 20 y el 60. Eso se debe, entre otros factores, a la debacle (o al agotamiento) de los proyectos populistas y nacionalistas en América Latina (1997; 13).

De tal forma puede observarse que el sentimiento de apego a nuestra nación en ese impulso romántico que heredamos del siglo XIX a manera tardía, incubó en nuestra América Latina movimientos de corte socialista o, en su defecto, pretendidamente democráticos, detonantes ideológicos de las más sanguinarias revueltas que haya podido padecer nuestra nación, como lo atestigua la fecha inolvidable del 9 de abril de 1948. Y no obstante, pese a la lejanía en el tiempo que dicho movimiento intelectual posee, el nacionalismo, aún se oyen voces de fraternales repúblicas conminando a un proyecto ya fracasado históricamente. Dicho fracaso se le atribuye, en gran medida, no a la causa de una peculiar situación socio política de una nación determinada, sino, todo lo contrario, a raíz de no haber considerado una peculiar constitución sicológica de los seres humanos en su pluralidad, los cuales no se encuentran, ni en un futuro próximo lo harán, dotados de la paciencia necesaria para esperar una intervención estatal paternalista en sus vidas (cfr. Gómez Valderrama, 1971; 7-24) ni, mucho menos, a permanecer en un status quo.

Empero, pese a lo productivo de este reconocimiento de búsquedas de lo propio, debemos acortar el paso en este camino introductorio y definir el tema de lo que es para nosotros lo propio. Además de lo anterior, la señalización de lo variopinto de nuestra particularidad geográfica, añadido a un sentimiento de apego al suelo en donde hemos nacido, comprendido en este lugar como lo autóctono, podríamos anotar incluso que existe algo de aquello que denominamos lo propio en la forma de adquirir una postura ante el mundo de unos seres humanos determinados. Es así que en nuestra particular manera de obrar en lo cotidiano, como lo hacemos a menudo desde el alba hasta la noche, de amar (cfr. Stendhal, 1953; 107 - 155) y, quizás, sin darnos cuenta, también al encarar una conversación o, simplemente, al redactar, como ahora se hace, un pensamiento atestiguado por los luctuosos signos de la escritura, designamos este algo con un aroma de propio que lo hace sumamente singular $\mathrm{y}$, al tiempo, consciente.

Pero todo esto se viene abajo si nos atrevemos a pensar más allá de lo que ven nuestros ojos. De tal suerte que si nos apresuráramos a mirar de una manera diferente y no nos detenemos en la información que nos suministra el cuerpo ${ }^{8}$, 
provocando una referencia al propio universo fáctico como algo denominado en realidad lo propio; si nos detenemos por un momento a pensar que en realidad, más allá de lo que simplemente se nos manifiesta a los sentidos en su inmediatez, exista algo fundamental, un algo que circunvale e inhiera el significado y el uso de lo propio, entendido ello como el factor que nos determina.

Detengámonos un momento. ¿Qué es eso que puede ser algo que circunvale e inhiera lo propio? Esto, ya lo hemos anotado con antelación, no puede ser en su forma fundamental y determinante una parte del bosque, un trozo de madera peculiar, una fauna exótica de la que hagamos gala o, tal vez, un paisaje turístico, ni tampoco lo hace nuestra peculiar manera de afrontar el día a día, aunque, no podemos negarlo, ello también conforma un sector de lo que entendemos por lo propio; no obstante a ese catálogo de facticidades en donde los movimientos actuales hallan lo propio, avocados por el impulso al que nuestro cuerpo nos arroja en ese primer contacto con el mundo inmediato, los elementos de aquello que conforman lo propio no son condición suficiente para nombrar a algo de tal manera y menos aún, para hallar ahí una conciencia de lo propio. Debe existir algún elemento que detone en nosotros la conciencia de lo propio y que no sea necesariamente exterior a nosotros, que no sean esas partes de la naturaleza conformantes de nuestro parámetro de visión acerca de lo que conforma, como lo hemos señalado, el factor que detona en nosotros una conciencia de lo propio.

Debe recordarse que al hablar de conciencia sometemos a un algo determinado a un examen. Al hacerlo, aquello que denominamos de tal modo, por el nombre de conciencia, adquiere para nosotros un sentido al quedar explicado. Heidegger, quien ha meditado más que nosotros el valor de esta palabra y lo que ella refiere, al recorrer sus Caminos de bosque indica: "La conscientia es la reunión representadora de lo objetivo con el hombre representador dentro del círculo de la representabilidad garantizada por este" $(2001 ; 89)$. Esta frase, que parece de inspiración sibilina o, quizás, prohijada de los oráculos píticos pronto halla su explicación. Heidegger hace resonar la palabra conciencia en el término latino conscientia que etimológicamente es cum scientia y que traduce con explicación o, mejor, con argumento. Es ella, la conscientia la encargada de hacer que algo para nosotros tenga sentido sin que ese sentido excluya al hombre y, mucho menos, aquello que lo constituye como ser humano: el lenguaje. Esto último garantiza la representabilidad, la capacidad de tornarse signo de aquello que se pretende dar a entender, es decir, del objeto determinado. Así, podríamos decir que para señalar que exista una conciencia de lo propio, entendido ello como un objeto particular, sea un ave o un pedazo 
exótico de bosque, deberíamos mediante el lenguaje, y en relación al humano que lo piensa, argumentar razonablemente sobre ello mismo, estableciendo así las posibles diferencias y semejanzas con otras aves o pedazos de bosque de otros lugares del mundo.

Tal vez, lejos de lo objetual que es hasta donde el momento, en su mayoría, hemos indagado y que, al tiempo se torna en la característica esencial del mundo material, sea necesario buscar aquello que detona en nosotros una conciencia de lo propio en un factor formal. El tiempo, nos ha enseñado el más ilustre, si no el único, reputado pensador de la población de Koningsberg en la Alemania dieciochesca, conforma nuestro parámetro formal de percepción del mundo (Cfr. Kant 1998; B 46-53). Ahora bien, más que aquello que se hace de una manera inmediata en la percepción, por extensión podríamos señalar que el tiempo puede asumirse también como una forma de medir lo sido, es decir, el paso del hombre por el mundo. De tal suerte no estaríamos, así, lejos de señalar que aquello que somos cada uno como historia, lo que acontecemos como temporalidad, como entes particulares que hacen parte de una civilización y que, de manera conjunta, poseemos una conciencia de la brevedad de la existencia, sea esto el objeto fundamental que determine en nosotros una conciencia de lo propio. Tener a esto, la conciencia del paso de nuestra existencia, del deterioro de nuestra materialidad como algo esencialmente propio, constituye un primer paso hacia el desciframiento de aquello que circunvala e inhiera el significado y el uso del elemento que detone en nosotros una conciencia de lo propio. Tener una conciencia de lo propio basado en nuestra historicidad, es sabernos conformados en su forma más peculiar de eso que el poeta argentino, amalgama de ceguedad y lecturas, no pudo denominar más que de una manera, recordando falsamente a Heráclito: "misterioso tiempo" (Borges, 1980; p. 60).

Con toda esta cantidad de elementos que anunciamos como conformantes de lo propio no hemos dado un gran paso. Ello nos lo anuncia el propio Peter Elmore cuando señala:

(...) es comprensible que en la retórica de la identidad nacional se adjudique tanto valor al territorio y a la historia, ya que ambos asientan en el espacio y el tiempo la convicción de pertenecer a una comunidad de compatriotas a un pueblo (1997; 12-13).

Empero, la nota característica de nuestra búsqueda es que no podemos pensar que solo en esta dirección ha de encontrarse lo propio y, menos aún, que ello sirva inconscientemente a los ideales de un Estado. 
Así entendida nuestra búsqueda, no es en el apego desenfrenado al propio terruño, al suelo del que como árboles brotamos, ni en nuestra peculiar forma de comprender el mundo, que pueda residir, como tal, una conciencia de lo que somos, es decir, de lo que tenemos de profundamente propio. No puede llamarse así, conciencia, en tanto que nuestra propiedad, lo que realmente tenemos que sea lo propio, no puede señalarse como algo tautológico sin más; ello debe establecerse en un sano ejercicio de nuestra capacidad de reflexión en relación con algo que sea completamente distinto, con algo que sea lo otro, para hallar, así, en tal dialéctica, su principio de individuación, su verdadero sustrato en el cual resida la esencialidad de lo que entendemos por lo veramente propio. Allí, en la interrelación de dos entes completamente distintos que se reconocen como disímiles pero que, al tiempo, se permiten el acto de dialogar es, sin dudarlo un instante, el lugar en donde puede brotar como elemento una conciencia de lo propio. De esta manera, al mantener una relación consciente con lo propio y establecer con ello, lo propio entendido como historia, un vínculo, hemos de señalar que preguntar por lo propio es preguntar por nuestra conciencia histórica. Al hacerlo, señala Gadamer, inquirimos por una tradición que viene acompañada de un sinnúmero de cualidades. Gadamer indica: "Así la tradición (filosófica, histórica, cultural) se convierte para la conciencia histórica en fuente de reconocimiento, es autoencuentro con el espíritu humano (1993; 35)".

De tal suerte, el hombre al indagar en la tradición lo que hace indirectamente es encontrarse consigo mismo, hallar de nuevo un pasado que se le mostraba nublado $y$, ahora, se presenta ante él como un cielo despejado.

\section{Diálogo de tradiciones}

Pero sucede que hemos señalado el diálogo, igualmente como el elemento que detona una conciencia de lo propio. Se ha indicado que una relación dialogal sólo puede establecerse entre dos entes ajenos, disímiles entre sí. Dichos entes en nuestra indagación son la diada que componen cada uno dos historias, dos tradiciones, diferentes. Esos dos entes que dialogan se encarnan en nuestra historia y la historia de Occidente, el encuentro de dos mundos que se hacen presentes precisamente en lo que Europa ha denominado El Nuevo Mundo

En esta dirección apunta la reflexión de Vasconcelos cuando indica una diferencia capital en la forma de aprehender el mundo entre las dos tradiciones. En La raza cósmica se lee:

La ventaja de nuestra tradición es que posee mayor facilidad de simpatía con los extraños. Esto implica que nuestra civilización, con todos 
sus defectos, puede ser la elegida para asimilar y convertir a un nuevo tipo a todos los hombres. En ella se prepara de esta suerte la trama, el múltiple y rico plasma de la humanidad futura. (1999; 29).

Sí, es bien es cierto, tal y como se aprecia en la cita, en la reflexión de Vasconcelos, existe la preocupación por "dignificar" a Latinoamérica en términos de superioridad racial en medio de una clara distinción entre dos civilizaciones. No obstante allí, en dicho intento, Vasconcelos halla pronto la caída para nuestra comprensión actual del mundo conforme a lo enunciado por él. Ahora se descree de proyectos como este y se pone en cuestión, incluso por los sociólogos, la palabra "raza". No obstante, pese a las dificultades que el texto La raza cósmica presenta, él nos indica el camino de un pensamiento, la búsqueda de una tradición que, como veremos y correctamente anota Vasconcelos "tiene mayor facilidad de simpatía con los extraños" (Ibíd).

Así, más que ser esta una indagación acerca de lo propio, una pregunta por nuestra tradición en confrontación con la de Occidente, es simplemente la presente una inquisición por la conciencia que tenemos de eso mismo, por una conciencia de lo propio, es decir, por una conciencia de nuestro andar en el tiempo, por lo que hemos sido en conjunto como civilización, como historia. Debemos aclarar que hablamos de una conciencia de nuestro transcurso en el tiempo no como seres que hemos vivido eternamente desde el albor de los primeros instantes de la vida humana hasta el momento, sino como aquellos seres que por poseer un intento de memoria colectiva, (memoria que por lo demás es siempre imprecisa, gregaria, ecléctica) cifrada en la escritura, podemos señalar unas condiciones de vida anteriores a las actuales a través de la consulta en ese intento por legar a los otros un testimonio, una comunicación de lo vivido. Ello, la conciencia de nuestro transcurso en el tiempo, puede manifestarse de maneras múltiples.

Bien podemos ser conscientes de una manera profundamente individual o bien en relación a otro. No obstante la primera depende enormemente de la segunda, es decir, no poseeríamos una conciencia definida de algo que no hemos hecho nuestro ya intelectualmente, como idea, si no se nos hace presente. Esa forma de hacérsenos presente puede aparecer en la interacción con el otro, es decir, en la comunicación con ese que, ajeno a mi individualidad, puede captar lo que para él soy. De tal forma podríamos indicar que el factor que hace que tomemos conciencia de algo es sólo la compleja cuestión del diálogo.

El diálogo, en su acepción completamente etimológica, proveniente del griego antiguo. De dicha lengua toma el adverbio dia, que significa en nuestra lengua, el español, a través de, sumado a la palabra griega lógo, que ha conservado hasta nuestros días el significado y el uso como palabra, tratado o discurso, pero también 
y esta es la acepción que quisiéramos tomar en este aparte del texto, pensamiento. Así pues, el ir a través de las palabras no es más que ir mediante los pensamientos. El pensamiento es más que una información una formación, es decir que él depende para su exposición, no de una idea suelta por brillante que esta sea, sino de ser capaz de argumentar con palabras sobre esa misma idea, defenderla, haber convivido con ella durante mucho tiempo. De tal forma el diálogo, esa sustantivación del ir a través del pensamiento, sólo se lleva a cabo en un ejercicio dialéctico, si se quiere en la propuesta hegeliana de tesis-antítesis, en el cual se coloque en juego dos concepciones de mundo ${ }^{9}$, es decir dos tradiciones.

En la indagación que se presenta, estas formas de dialogar hacen referencia a un acto llevado a cabo entre dos tradiciones. La palabra tradición, como ya lo hemos mencionado tanto en Gadamer como en Vasconcelos, indica la sustantivación de aquello que es legado. Proveniente como tal de la palabra latina trāditĭo, ōnis, (Blanquez Fraile 1961; 1736) la cual señala la idea de que hay algo que es entregado y transmitido, pero también que es algo portado con nosotros, que portamos; la tradición designa el acto por medio del cual entregamos y recibimos para conservar sus memorias, la presencia de otros seres, la riqueza de sus vivencias en nosotros ${ }^{10}$. Esa riqueza no es simplemente una, es una riqueza que en este texto, y a propósito de la única novela publicada de Pedro Gómez Valderrama, se pretende indagar como algo dual y al tiempo múltiple en sus implicaciones. En primer lugar existe en esta indagación la referencia a una tradición que es profundamente propia, tanto formal como en sus contenidos. En cuanto a lo primero el problema reposa en la selección del género escogido para la elaboración de la novela; en cuanto a lo segundo, sus contenidos, ese diálogo de tradiciones se muestra en un legado que es íntimamente nuestro al cobijar la propia territorialidad además de nuestra espacialidad y, a la par, otra que es completamente diferente, ajena, que permea la geografía del antiguo continente pero que, al tiempo, se ha introducido ideológicamente en nuestra temporalidad: la tradición del antiguo mundo, Europa en confrontación con la naciente historia de América (entendida como América Latina).

\footnotetext{
9. Para el uso de este término en lo que viene del presente texto $c f r$. infra. p. 94 y ss. Cabe señalar que dicho término ha de ser empleado con sinónimos como forma de ver el mundo, cosmovisión, manera de ver el mundo, comprensión de mundo, imagen de mundo y noción de mundo.

10. A propósito del significado de esta palabra en uno de los más grandes exponentes de la crítica literaria, Bajtín, se lee: "Las tradiciones culturales y literarias (incluyendo las más antiguas) no se conservan ni viven en la memoria individual subjetiva de un hombre aislado, ni en ninguna "mentalidad" colectiva, sino en las formas objetivas de la cultura misma (incluyendo las formas lingüísticas y verbales); están, en este sentido, entre lo subjetivo y lo individual (y son, por lo tanto, sociales) de ahí pasan a las obras literarias ignorando a veces por completo la memoria subjetiva-individual de los creadores" (1991; 399).

De tal forma, como puede verse, tanto desde la filosofía como de la crítica literaria hay una confluencia en considerar la tradición como una memoria colectiva que supervive al olvido a través de la escritura.
} 
Ahora bien, como el rótulo de nuestro texto lo sugiere, la indagación ha de hacerse desde una base literaria al tiempo que propia. Hemos tomado para ejecutar este acercamiento hacia lo propio, es decir hacia lo que llevamos con nosotros en este río del tiempo, nuestra tradición, una narración colombiana elaborada por un escritor santandereano: la novela de Pedro Gómez Valderrama denominada La otra raya del tigre. En ella el diálogo entre tradiciones es un hecho flagrante. En cada página, en cada línea e, incluso, en la forma en que cada línea que el gran escritor nos deja, hallamos ese diálogo de nuestra tradición con una tradición que es completamente europea, ajena a nuestra territorialidad, incubada en otras fronteras espaciales. Para encarar dicho diálogo de tradiciones en relación a los contenidos de la obra tomaremos como figuras emblemáticas a dos personajes de la obra forjada por el antiguo ministro de educación: el abuelo, Juan de Dios, como exponente de esa tradición que es profundamente propia $y$, al tiempo, como un personaje que se consolida como puente, si se quiere denominar de tal forma, entre las dos maneras de ver el mundo; de otro lado encontraremos a Geo Von Lengerke, el cual es el heraldo de la tradición que viene del antiguo continente. En medio de este diálogo de tradiciones que se hace evidente a partir de la configuración psicológica de cada uno como personaje verosímil de la novela, es lo que esperamos demostrar en las páginas que vienen, hay un esfuerzo por cimentar una conciencia histórica, una lid por acercarnos a lo fundamentalmente propio, de aproximarnos a nuestra tradición de una manera bien particular. No puede ser otro el sentido de ese dialogar entre dos tradiciones que son sumamente contrapuestas pero no mutuamente excluyentes.

Tal vez en esa dirección de concebir el diálogo entre dos tradiciones como un elemento que detona en nosotros una conciencia histórica, apunte el señor Lukács, referente teórico ineludible para esta investigación, lo siguiente:

(...) la creciente significación de los diálogos, o sea de la inmediata discusión de elementos opuestos a través de la conversación, todo ello debe verse en estrecho nexo con el afán de plasmar, en la realidad histórica tal como realmente había sido, con autenticidad humana pero de tal modo que el lector de épocas posteriores pudiese revivirla $(1971 ; 42)$.

Tenemos así que la inmersión del diálogo en la obra literaria tiende a hacer posible que las diferencias en un periodo histórico determinado broten, que se haga así notoria la forma en que se construye una época histórica en torno a las polaridades de sentido que las inundan, que las hacen hablar a través de los personajes que les encarnan y que, al encarnarlas mediante el diálogo, nos colocan junto a ellas retrotrayéndonos del presente en el que encaramos el difícil ejercicio de la lectura hacia la época histórica que nos narran, colocándonos hipotéticamente en su misma situación. 
Para poder señalar esto que acontece en la reflexión literaria de Gómez Valderrama nos es necesario recurrir a una serie de anotaciones procedimentales, que como vimos pueden ser extenuantes pero de una necesidad excusable en la planeación de nuestros razonamientos y que han de venir de manera posterior a esta sección introductoria. Es necesario, por completo, señalar, en una primera instancia, qué clasificación merece la obra de Gómez Valderrama, es decir, si en realidad podemos pensar que la novela del innumerable prologuista colombiano pertenece en su aspecto formal a ese género de la literatura llamado novela histórica $\mathrm{o}$, contrario a ello, señalar que su reflexión literaria pertenece a ese género de novelas que se conoce en el ámbito del análisis literario como la nueva novela histórica ${ }^{11}$. Para ello nos es menester hacer un recorrido por lo que ambos términos han indicado, aspecto que ocupa los capítulos I y II del presente texto; posteriormente haremos una indagación en torno a la consideración del autor de La otra raya del tigre, brevemente a su obra en general y a su narración novelada en particular; luego nos detendremos ampliamente, como ya lo habíamos señalado, en una inquisición a los personajes del abuelo, Juan de Dios y Geo Von Lengerke, mediante una variante del método psicocrítico de análisis literario, como indicios de lo propio y lo otro, respectivamente, en la configuración de ese diálogo de tradiciones a partir de sus visiones de mundo y así, de esta manera, señalar qué es aquello propio de nuestra tradición y, de otro lado, lo propio de la tradición europea en la obra de Pedro Gómez Valderrama. De esta manera, indicando nuestro camino, démosle vía libre a la primera parte de nuestro andamiaje procedimental y señalemos, determinando ciertas particularidades de los géneros novela histórica y nueva novela histórica por qué la novela de Pedro Gómez Valderrama no puede ser, como el autor mismo ya lo ha señalado, más que una novela histórica y no una nueva novela histórica ${ }^{12}$.

Para elaborar este marco conceptual, el ámbito por el cual se ha de conducir nuestro pensamiento, hemos tomado fundamentalmente, en reiterativas y esenciales ocasiones, de Georg Lukács una reflexión acerca de la forma crítica en que se realiza un texto literario sobre aquello que puede bien considerarse como una novela

\footnotetext{
11. En la reciente indagación del profesor Solanilla, este término aparece referenciado como escritura postmoderna (Cfr. Ibid; 31-4).

12. Cabe resaltar que en este lugar acudiremos a la confrontación de algunas obras que reflexionan acerca de la novela histórica y la nueva novela histórica. En cuanto a las primeras, encontramos cifrada la reflexión sobre dicho tema, en los siguientes autores y textos: Georg Lukács (1971) La novela histórica, Espinosa, Germán (2002). Ensayos completos; Celia Fernández Prieto. (1998). Historia y novela: Poética de la novela histórica; Amado Alonso, (1942), Ensayo sobre la Novela Histórica, y Peter Elmore, (1997). La fábrica de la memoria. Respecto al segundo género literario a trabajar, el de nueva novela histórica debemos indicar que nuestra reflexión se reduce casi exclusivamente a la obra escrita por Seymour Menton (1993) y al artículo publicado por Fernando Aínza (1991), además de la ya referida obra del profesor Solanilla.
} 
histórica ${ }^{13}$ en el sentido clásico de la palabra. Este texto que no es más que un rastreo de la manera en que algunos reputados novelistas como lo son Walter Scott, Alejandro Dumas, Balzac, Stendhal y otros, llevan a cabo el ejercicio de escribir un relato que, a su vez, tiene profundos vínculos con los acontecimientos históricos de las épocas que relatan pero, no obstante a dicha vinculación, sin ser a la littera un relato acerca de la historia. Así es que, haciendo un rastreo por lo que ha sido la novela histórica, aclararemos el "concepto" de novela histórica a fin de tener un andamiaje formal con el cual orientarnos en la narración novelada de Gómez Valderrama. Contrapuesta a la elaboración del "concepto" de novela histórica, en gran medida fundamentado en la obra de Lukács, hemos de tener la mirada acerca de ese otro género de la literatura denominado nueva novela histórica basados, casi exclusivamente en la obra de Seymour Menton, en la cual procuraremos hallar el marco teórico que nos acerque a la definición del "concepto" de nueva novela histórica. Posteriormente a haber construido nuestro marco conceptual debemos obtener evidencia del texto mismo de Gómez Valderrama e incidentalmente de algunos apartes de su obra que nos indiquen, en conjunto, cuál de los marcos conceptuales encaja mejor para la clasificación de la novela en cuestión y por qué se hace de tal manera, aspecto que se trabajará cuando hagamos algunas reflexiones previas a La otra raya del tigre. De acuerdo a esta nota procedimental procuremos forjar el primer "concepto" que hemos señalado. 


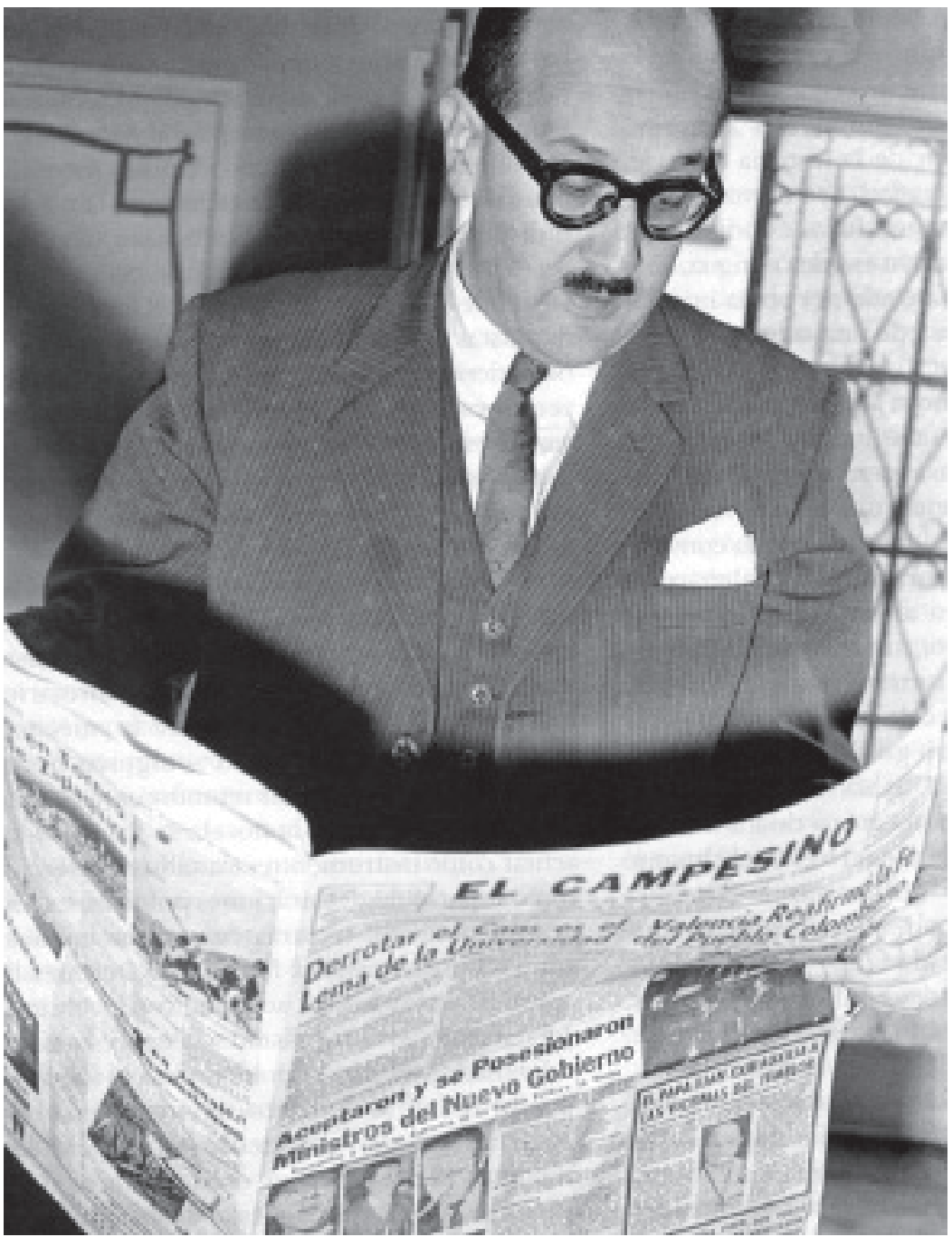

Imagen tomada de la Revista de la Universidad de Antioquia

(2006; Abril-Junio) Número 284, p. 62 
CAPÍTULO UNO 


\section{Apuntes para la comprensión del "concepto"14 de novela histórica}

El novelista tiene necesidad de alguna máscara esencial formal, de género, que defina tanto su posición para observar la vida, como su posición para hacer pública esa vida.

Bajtín

Esta primera parte de nuestro texto, esquirla de un andamiaje metodológico ya propuesto, procura esclarecer lo que se entiende en el pleno rigor de la teoría literaria como novela histórica. Dicho procedimiento de esclarecimiento sobre el tema se ejecutará procurando forjar un "concepto" de novela histórica ante la pluralidad de visiones que hay sobre el tema. De tal forma, una vez señalado nuestro objetivo en el presente capítulo, debemos indicar las partes que comprende la elaboración de dicho "concepto" con el fin de dar una mayor claridad a la implicación que tal "concepto", el de novela histórica, señala. Un primer paso lo constituye, aclarar el término de novela histórica a partir de su respectiva bifurcación en la meditación de los términos novela e historia; tendremos, así, como segundo paso que esclarecer el "objeto" de estudio correspondiente a la novela histórica, entendido este como la cuestión sobre la cual ha de versar una narración con tal calificativo. El tercer y último de los pasos a favor de construir el "concepto" de novela histórica será el de analizar la vinculación con la verdad de hecho, es decir, el papel que juega la novela histórica en tanto que referida a unos acontecimientos determinados y registrados ya bajo el ojo de la pretendida "ciencia" histórica. Con ello, con el paseo por estas dos categorías que conforman nuestro "concepto" de novela histórica, esperamos ofrecer una amplia visión de lo que entendemos por este al interior de la crítica literaria.

\footnotetext{
14. Es bien cierto que el saber de la literatura no trabaja con conceptos a la manera en que la filosofía los maneja. Dicho punto, el no trabajar con conceptos filosóficos hace que la literatura interprete algunos términos de cuño filosófico con una subjetividad y falta de precisión que la filosofía no tarda en señalarle. Empero, siendo que en este lugar y en el capítulo siguiente se trabajará en el campo de la teoría literaria a fin de esclarecer tanto el género de novela histórica como el de nueva novela histórica, tomamos de la filosofía, con sumo cuidado esta palabra, "concepto", puesta así, entre comillas, para llamar la atención sobre la delicadeza, el margen y al tiempo un punto de encuentro que se pretende establecer entre la literatura y la filosofía.
} 
De entrada, es necesario manifestar que no es ya posible pensar en el terreno de la literatura el "concepto" de novela histórica ${ }^{15}$ sin antes referirnos a un grande de la teoría literaria, Georg Lukács. En una primera referencia encontramos ya a Lukács indicándonos el camino que hemos de seguir si nuestro propósito es arribar al conocimiento esencial del asunto al que hace referencia el pretendido (por nosotros) "concepto" de novela histórica, eso sí, a modo de sutil ejemplo. Lukács señala:

En una crítica a la ya olvidada novela histórica Leo de Latouche comenta: "La novela entera sólo consta de 200 páginas en que se tratan 200 acontecimientos; nada revela mejor la incapacidad del autor que la acumulación de hechos...El talento florece cuando se describen las causas que provocan los hechos, florece en los misterios del corazón humano, cuyos movimientos descuidan los historiadores. Las personas de una novela se ven forzadas a ser más racionales que las personas históricas. Aquellas deben despertar a la vida, estas han vivido. La existencia de estas no requiere pruebas, por curiosos que hayan sido sus actos, mientras que la existencia de aquellas necesita de un general consenso". Es obvio que cuanto más alejado se halle un periodo histórico, con las condiciones de vida de sus actores, tanto más se tiene que concentrar la acción en presentarnos clara y palpablemente esas condiciones de vida, para que no miremos la peculiar psicología y ética resultante de estas condiciones como mera curiosidad histórica, sino para que revivamos una etapa del desarrollo de la humanidad que nos interesa y nos conmueve" (Lukács, 1971; 44 ${ }^{16}$ ).

15. Es esta composición esencial de la palabra la que no entienden precisamente quienes se encargan de llevar a cabo una crítica de la novela histórica. Se erige con alguna premura una alusión en contra de la novela histórica señalando que ese relato que se encuentra contenido en la expresión antes mencionada no es fiel a los contenidos de la propia historia. Contra esta argumentación se enarbola un argumento que está íntimamente unido al descuido gramatical y morfológico del lector. En la composición misma de la palabra hablamos aquí de un relato que tiene como coordenada para su elaboración pero no como fin último el saber de la historia, por ello es histórico. Un segundo argumento lo podemos hallar amparándonos bajo la tradición literaria. (Un poco más de detalles serán expuestos más adelante en este mismo capítulo en el apartado al cual se le dedica un momento especial al análisis correspondiente al adjetivo histórico (p. 34-37) y ese otro en el que señalamos la Relación con la verdad de hecho).

Pese a lo anterior, la falta de sutileza de Stendhal, consagrado a la escritura en este género, no ayuda mucho al momento de esclarecer este escollo cuando en Del amor indica: "En primer lugar, yo no soy más que un historiador" (1953; 134) y más aún en las palabras preliminares a una de sus primeras novelas, Armancia, cuando anota : "(...) si al público se le presentara un espejo, ¿Qué culpa tiene nadie de que las gentes que pasen por delante sean feas? ¿A qué partido pertenece el espejo? “(1969;49) Sin embargo, pese a la autoridad que el escritor de La cartuja de Parma encarna en la tradición literaria occidental, y más aún en la conformación de la novela histórica, discrepamos de tal consideración, de asimilar tal género literario al saber de la historia, con algunos argumentos, no solo porque hemos observado ya en el andar de la historia a que se reducen las observaciones juiciosas y objetivas, preocupación fundamental del siglo XVII a nivel tanto de filosofía como de literatura, sino a la relación entre historia y novela como se verá en lo que viene del capítulo.

16. Debe añadirse que quien realiza la crítica a la novela de Latouche no es más que otro de los grandes de la literatura, Balzac. 
Teniendo como subsuelo esta cita, que por lo demás es exageradamente extensa y abundante en cada una de las frases descriptivas que, al unísono, son propicias para nuestra indagación, procuraremos haciendo uso de palabras ajenas, escoger algunas que se avienen con nuestro propósito en la indagación, no obstante procurando ser fieles al sentido del texto de Lukács. Empero ello ha de hacerse de manera posterior. Por lo pronto, y dejando a Lukács un poco de lado, hemos de mostrar algunos apuntes globales sobre la novela histórica en un ejercicio preliminar conducente a la elaboración del término como "concepto". Baste la cita de Lukács para hacer una presentación inicial del texto. Observemos, tan solo de pasada antes de entrar a discutir la cita que Lukács nos refiere, que la afirmación de Lukács se encuentra signada ya, de hecho, por lo que el mismo nombre nos señala (por el de novela histórica). Entenderíamos mejor su nombre si apegados a la letra escindiéramos las dos partes del término que conforman la expresión novela histórica para ser analizada. De esta manera, una vez sacada de su estado originario, escindida la palabra novela (sustantivo) de esa otra que es la palabra histórica (adjetivo), hemos de quedarnos con el primer término, novela, con el fin de analizarlo en su mayoría de implicaciones.

\section{Un acercamiento al término "novela"}

Para darle inicio a tal análisis tendremos que mostrar cómo usamos en nuestra cotidianidad la palabra novela. Entendemos por novela en nuestra contemporánea racionalidad, forjada ella por el influjo de los mass media, algo muy semejante a lo que esta, en sus inicios, ha sido. La novela se ha formado por un sentimiento necesario en el hombre, una sensibilidad aguzada desde el Renacimiento hasta nuestros días, esa de ver siempre lo nuevo. De allí que en nuestra cotidianidad, sentados frente a ese gran representante de los mass media que es el televisor, en la actualidad un poco relevado por efecto del Internet, encontremos lo que antes hallábamos en libros: novelas. Esas novelas, se caracterizan por presentarnos nuevos sucesos inmersos en una vida que posiblemente fuera la nuestra. Así, sin poder desprenderse de su etimología, atada a la imagen de un televisor, pronunciamos la palabra "novela" con el fin de designar ese cúmulo de imágenes puestas en la otrora condenada "caja maldita". De tal suerte la palabra novela (proveniente del adjetivo latín novellus -novedoso- en su forma femenina), conserva lo que en su inicio propone su bautismo. Lo novedoso, o aquello que nos entregan día tras día las novelas televisadas es, con mucho, un cúmulo de sentimientos entrelazados, dispersos sobre los personajes (encarnados en los actores) que muestran los efectos de dichos sentimientos cada vez de forma más vivida. Estas novelas que, en la mayoría de ocasiones recuerdan la predecible trama y desenlace de una novela bizantina, no hacen nada diferente a suplir un gusto y, no obstante, son ya, al estar en un contacto 
inmediato con ellas, un primer acercamiento a ese mundo que ya no pende de la imagen ni se ancla al sonido como boleto de entrada, sino que se sostiene en un universo en donde habitan las letras supliendo el lugar de la imagen y reina, como telón de fondo, el sublime silencio.

Alejados ya de toda percepción inicial, artefáctica, de lo que sean las novelas, $\mathrm{y}$ anclados al mundo silente de la lectura debemos señalar que estas fueron, en su albor, un género nuevo. Con un acentuado doble inicio aparece ante nuestros ojos ese género nuevo que es la novela. Carlos García Gual, a propósito de esta tarea de descifrar el punto inicial de donde se constituye la novela apunta lo siguiente:

La palabra tuvo su orígen como término jurídico: "novella"= novedad en el Código Justiniano, referida a un añadido o ampliación de una ley anterior. Pero, en el sentido de "relato breve sobre un suceso nuevo y curioso" pasó del provenzal al italiano en el s. XII, y de allí a los demás idiomas europeos. Con el sentido de "novela breve" se consagra como nombre de un género literario en el s. XIV: el Decamerón de Boccaccio es de 1353. Así nombra Cervantes sus Novelas Ejemplares. En Alemania la palabra se usó como término literario hasta el último tercio del s. XVIII (Cf. B. Von Wiese, Novelle Stuttgart 1969. $4^{a}$ ed.). La denominación de "Roman" aplicada en sentido estricto al género literario de la novela aparece por primera vez usada en francés por Chrétien de Troyes (último tercio del s. XII) (1972; 15-16).

En este prolijo aparte hallamos pues una historia de la palabra reducida a su mínima expresión. Esa historia, ese uso de la palabra novela desde el auge del Imperio Romano y la consolidación del cristianismo como única religión, hasta el dominio de la lengua francesa nos narra una serie de vicisitudes; cautiva por el tiempo y los hombres que la han usado, la palabra nos señala que sólo hasta una época tardía, el último tercio del siglo XII, se puede hablar con plenitud de la palabra novela adjudicada a un género literario plenamente constituido. Antes de esta época, el último tercio de siglo XII, sólo podemos aventurar conjeturas, hacer presunciones, cavilar hipótesis acerca de posibles intentos predecesores de los géneros coadyuvantes a la aparición como tal de la novela. Esto último constituye el esfuerzo, significativo en gran medida, del profesor Carlos García Gual en su indagación por el Origen de la novela. Nótese cómo el autor, que no gratuitamente ha coqueteado con la filología, titula a su texto Origen, a despecho de Inicio o Comienzo, aspecto que hace posible llevar a cabo un rastreo de aquello que ha precedido a lo que como género literario es la novela.

Ahora bien, previo al último tercio del siglo XVII, que es como tal -ya lo habíamos señalado- donde se constituye la novela, hallamos unas narraciones que 
bien pueden servir literariamente si se las mira -y esto es una manera muy sesgada de observar el asunto- como un paso histórico casi necesario en la construcción del género que aparece en el último tercio del siglo XII. De tal suerte, acuñada bajo la "vulgaridad" potestativa de la lengua francesa, la novela, asumida como roman nos muestra, en los inicios de la modernidad europea, un mundo completamente opuesto a la vida monacal y pastoril tanto de la "oscura" Edad Media como del "inicial" periodo griego. Las pasiones de los seres humanos, hombres y mujeres entre sí, sumadas a un breve acceso a la lectura, ya no sólo monopolizada por la vida clerical, van construyendo, palmo a palmo, letra a letra, en el ir y venir de los días, esa firme base sobre la cual se cimentaría posteriormente una de las últimas puestas en común de la cultura universal: el Romanticismo.

La palabra novela, ya entrada en el siglo XV sigue teniendo esa connotación de la palabra latina novellus (novella, novedoso). Lo que era novedoso en esta ocasión, es su forma de ser entregada. De tal manera, la novela por entregas, es decir, lo que denominamos en el mundo televisado de las actuales novelas, capítulos, aumenta el suspenso y, entre suspenso y suspenso, espera y deseo, aumenta la trama que motiva al lector a entregarse a la lectura.

No obstante, pese a que hemos ya agotado al lector con la reiteración de la significación etimológica de la palabra novela a través del adjetivo latín novellus, tenemos que señalar algo que se opone precisamente a esta significación. La palabra que ha dado vida al género de la novela acaricia en su íntimo regazo, en el de la significación, cultivado con el más caro de los cuidados, un tema de profundo talante sentimental: el amor. Acerca de ello nos deja escrito García Gual una frase lapidaria: "El tema por excelencia de la novela es el amor" (1972; 112). La pregunta que no se hace esperar es la siguiente: ¿Cómo puede ser entonces que la novela, al tiempo que nos relata sucesos novedosos, ella misma haga uso del más antiguo de los sentimientos? La respuesta no pertenece al orden de la teoría, escapa de allí para afincarse en el mundo afectivo de la vida. Siendo el amor el más democrático de los sentimientos, es este, al tiempo, el más seductor de los temas; el encanto de la seducción radica en un punto básico, todos lo hemos llevado dentro o, por desgracia, le vimos, en algún tiempo, desvalidos, deambular por el frente.

Esto que acabamos de ver, el hecho de que la novela se alimente del amor como principal tema incumbe de manera fundamental a los contenidos de la novela, pero, en el aspecto formal (esto para quienes, a despecho de lo ya pensado por Bajtín, aún se afincan a la idea de que forma y contenido han establecido una disputa a muerte), hay otro tanto que señalar. La novela usa de la prosa para argumentar; en ella, lejos de la cadencia de palabras estratégicamente pensadas con el fin de 
formar un ritmo, ellas, las palabras, se desnudan con una sensualidad finamente pensada; acompañante diestra en el oficio de seducir la imaginación ante la idea, la palabra en la novela no sólo señala, despierta, alienta, excita ${ }^{17}$, sino que exhorta a la comprensión de una realidad fantasmal compenetrando al lector con ella; dicha realidad fantasmal labrada con imágenes se muestra a nuestra manera de pensar como efectivamente real.

De tal suerte, la novela forja un sentido de la realidad algo diferente, ella misma construye, en el ir y venir las imágenes que suscita la palabra, una apariencia de realidad que nos hace perder en ella. Así parece entenderlo el propio García Gual cuando recuerda, a propósito de la realidad de la novela una vieja historia. Veamos: "La novela ofrece un nuevo campo de vida. Como el pintor chino que decoró las paredes palaciegas con paisajes lejanos y luego se perdió por ellos, quisiera el lector penetrar por los caminos fantásticos que el libro le abre" (1972; 44).

Una realidad lejana en la cual corremos el eminente riesgo de abandonarnos a nosotros mismos, eso es lo que nos ofrece la novela; el extravío al que nos someten las palabras, medieval espejo del mundo, hace que nos desapeguemos de nuestro cíclico camino vital para despegar los ojos de nuestra vida y poder contemplar una realidad distinta, una realidad en la que ese animal simbólico que es el hombre, contempla un nuevo tipo de objetos, pensados ellos con otro medio que no es el del primario sensorium.

\section{Reflexiones en torno a la palabra "historia"}

Hemos señalado ya algo de la novela, nos resta el análisis de la otra palabra que conforma la expresión novela histórica, precisamente la palabra histórica. Debemos señalar que histórica, en la expresión que hemos tomado para nuestra indagación no es más que una palabra compuesta. La base originaria de la palabra es el sustantivo historia; lo demás, el sufijo ica, que se muestra al final de la palabra, puede bien descomponerse en dos partes; la primera de ellas en el morfema ic el cual señala dentro de los adjetivos, la posesión de una cualidad propia en relación a algo determinado. La parte restante, el morfema $a$, es propio de las palabras (cuando estas son sustantivos, participios, y adjetivos) pertenecientes al género femenino. De tal suerte, la palabra histórica, para hacer una pequeña síntesis, muestra solamente una relación o alusión al saber de la historia, es decir, que no es, con propiedad, historia.

17. Sí, tal vez el asunto pertenezca a la palabra poética, como bien lo atestigua el profesor Abad (2007; 129-36). Empero la novela usa, y así hay que entender lo poético de la palabra como “creación”, la palabra poética. 
La historia, en gran medida, desde Heródoto hasta principios del siglo XX y, particularmente en Colombia, se ha caracterizado por el neutral y objetivo abordaje de una situación pretérita o actual. De tal suerte que, comprendido de este modo, el saber de la historia, se nos revela como una descripción de lo que efectivamente sucede o ha sucedido; no es para nada una invención literaria o un mito, es la realidad vuelta escritura, hecha palabra, lo que la historia nos entrega.

Así entendida la historia, como disciplina intelectual con un transcurso en el tiempo que le es propio, se configura como aquella rama del saber que nos entrega una lección para la vida. Como se sabe la palabra proviene para la lengua española de la lengua griega. En ella encontramos la palabra istoria $^{18}$ (historia), con dicha palabra se piensa la forma de investigación que tiene un referente en el mundo de los sentidos a través de lo que podemos percibir por la vista, es decir que ella, la istoria es una datación de aquello que las personas han visto en el mundo fáctico. Así comprendido, el saber que esta disciplina nos narra se contrapone a la fabulación o a la mitificación de un suceso determinado, señalándonos el acontecimiento narrado sin ningún adorno poético. La nota diferencial entre la novela histórica y el saber de la historia, es que aquella ha de contar con un medio de expresión poético que la hace decir un poco más acerca de los contenidos que trae consigo, que el propio saber de la historia el cual se ha desvelado por el ideal de la objetividad en lo narrado.

Debe anotarse que no solo la cultura griega, hasta hace poco endiosada cual "milagro", ha contribuido a afianzar nuestra visión sobre la historia. El águila de Hipona, San Agustín, en su magnífica Civitas Dei (Ciudad de Dios) muestra un nuevo capítulo en la forma de concebir la historia: los hechos narrados por el santo se ordenan conforme a una idea fraguada en el íntimo seno de la esperanza, es ello lo que le hace pensar en una pronta llegada del reino de los cielos al mundo terreno. Conforme a esta idea que encierra la fuerza de una esperanza y que, por lo tanto funda un historicismo al procurar hacer una historia vaticinadora, profética, se orienta la visión sobre un mundo que ha comenzado a morir: el mundo antiguo.

Más tarde, en el andar de la palabra historia puede mostrarse como un pensador, aquel que hizo despertar a Kant de sus sueños dogmáticos, concibe la historia como una narración desprovista de intenciones subjetivas. Hume (1998) señala, aunque la teoría parezca un poco salida de tono para nosotros, cuando intenta escribir su Historia de Gran Bretaña, algo bien peculiar. Aquí, en una misiva que hace referencia 
a su obra, Hume aconseja que el historiador deba tener una serie de cualidades. A continuación dejamos al lector la juiciosa cita en donde se refiere tal suceso: "Estilo juicioso, imparcialidad, cuidado: todo eso falta en nuestros historiadores" (Hume, 1998; 44). Así pues, la preocupación por la elaboración de una historia al margen de las pasiones de los hombres, completamente objetiva, es la preocupación del pensador de Gran Bretaña. Y pese a ello, esta confianza absoluta en la fidelidad de la narración para la descripción de un hecho objetivo, podemos apreciar cómo en un texto autobiográfico, hay un anuncio de lo que podría a nuestro juicio, más no el de Hume, ser una terrible conclusión sobre esta preocupación por elaborar una historia objetiva

Confié con optimismo, lo admito, en el éxito de esta obra. [Historia de Gran Bretaña] Pensé que era la única historia que se había desentendido a la vez, del poder actual, de los intereses, de la autoridad y del griterío de los prejuicios populares. Y como la materia se encontraba al alcance de todos, esperé el correspondiente aplauso pero terrible fue mi decepción $(2002 ; 60)$.

Obsérvese en estas líneas cómo el más objetivo de los pensadores, considerado por la historia de la filosofía como la cúspide del empirismo, halla pronto el fracaso al pretender una narración que, siendo de índole completamente humana, pretende distanciarse de las inclinaciones de los hombres para narrar los sucesos objetivamente.

Sin embargo, cabe resaltar que la preocupación por el saber de la historia, por el contacto con lo que nuestros predecesores han sido en el tiempo, no ha tenido un auge tan grande en el decurso mismo de su caída en el tiempo como la Época Moderna lo ha mostrado. Nuestra época, heredera de los ideales de la Ilustración, toma por abolengo, de igual manera, la preocupación por la historia. Así lo expone el profesor Amado Alonso:

Pero el siglo de la Ilustración va a desembocar en el siglo de la Historia. El conocimiento documental del pasado se afina rápidamente. La historia aspira a constituirse en disciplina científica, y el hombre medianamente culto tiene ahora, como exigencia de su cultura, una información del pasado mucho más minuciosa $(1942 ; 39)$.

Expresado de esta suerte el legado de la Ilustración a nuestra época no puede ser más que el legado de la aspiración de la historia a consagrarse como ciencia. Esta aspiración es la que se puede tener cuando en realidad queremos poseer una conciencia del pasado: esto puede concebirse de tal manera en tanto que ciencia y 
conciencia son palabras que se encuentran unidas de suyo por su origen etimológico ${ }^{19}$.

Es necesario, entonces, recalcar que es aquí, en el instante del desarrollo humano de las ideas, en donde puede surgir tal preocupación. El escape a los argumentos de autoridad, argumentos que conformaron el andamiaje intelectual de la Edad Media, sólo puede ejecutarse a través de la puesta a prueba de los mismos enunciados que tales autoridades proferían (experimento) sumado esto a la conciencia de un yo pensante, autodeterminable en su racionalidad. Así, la puesta en marcha del valor concerniente a la historia no deja de ser uno de los pensamientos más recientes en Occidente.

No obstante con esta concepción de historia señalaríamos que ella es algo que no se puede modificar. Pese a tal definición debemos indicar que si bien la historia es algo que nos orienta en un futuro imprevisto en todo el rigor de los acontecimientos, hallamos también que es posible volver la vista atrás y modificar el asunto que alguna vez se pensó inmodificable por medio del mismo conjuro del tiempo que resulta ser la escritura.

Esta postura nos la muestra el propio Gómez Valderrama cuando nos comenta algo al respecto. En una narración depositada en su recopilación de cuentos denominada Invenciones y Artificios el escritor colombiano atestigua una concepción de historia bastante interesante:

En general considero que así como en el futuro hay para cada hecho, para cada actitud humana un sinnúmero de posibilidades a través de las cuales podría seguir caminos distintos, así las cosa de la historia que no están completamente establecidas, y en muchos casos también aquellas que parecen estarlo, ofrecen esas mismas posibilidades, pero el hombre, al irse hacia atrás para hacer historia, la fabrica a su manera, y para darle verosimilitud tiene también que matar las otras alternativas" $(1975 ; 61)^{20}$.

Con esta definición tan extensa hallamos una concepción de historia bien borgiana. En principio tenemos que la historia es simplemente una posibilidad; no la verdad monda y lironda, a despecho de la reflexión filosófica dieciochesca, si no el aproximamiento humano a una pluralidad de acontecimientos que bien pudieron ser de otro modo. Así se establece que la historia sufre el efecto de ser análoga a quien

19. Cfr. Supra p. 15 y ss.

20. Otras consideraciones sobre el término historia en Pedro Gómez se pueden observar en la Antología (1995; 186) elaborada por Jorge Eliécer Ruíz, de donde provienen las siguiente citas. 
la forja: estar abierta a la posibilidad siendo que su posibilidad de construcción es, al tiempo, la imposibilidad de dar una mirada total, omniabarcadora, a la misma ${ }^{21}$. De esto resulta que los esfuerzos por construir historias de la filosofía, de la literatura, de la historia misma se puedan resumir como generalizaciones apresuradas que echan al olvido lo esencial pero que no por ello deben dejarse de lado en cualquier estudio.

Así entendida la historia ella ha de tener dos significaciones diferentes: creación y búsqueda. A propósito de estas definiciones en torno a la historia el ex ministro de educación nos dice "ya sea como creación o como búsqueda. Las dos formas nos sirven para hacer nuestra historia: cuanto buscamos en los libros o cuanto hemos puesto en ellos". De tal forma tendríamos que la historia, conectada desde su origen con el saber de la escritura, es susceptible de re-escribirse. En ella hallamos la posibilidad de escapar a las narraciones monótonas cuando se muestra que puede ser narrada desde otro punto de vista.

\section{Sobre la novela histórica}

Nos resta entonces pensar la historia en relación a la literatura o, tal vez, la literatura en relación a la historia. Gómez Valderrama en la recopilación de escritos que realiza Jorge E. Ruíz nos dice: "por eso, la historia incorporada a la literatura no es simple recurso literario: es una nueva creación de una realidad diferente. Es retomar un hilo perdido, que va del pasado al futuro" $(1995 ; 197)$. Así pues la literatura se sirve del saber de la historia y, al hacerlo, simplemente reconstruye lo que dábamos por evidente. Observemos cómo el propio Dumas, tan admirado por Pedro Gómez, nos da una muestra de cómo opera dicho recurso a la interacción entre la literatura y la historia en Los tres mosqueteros: "No pretendemos aquí efectuar análisis alguno de aquella curiosa obra [Memorias de monsieur D’Artagnan], prefiriendo recomendarla a aquellos de nuestros lectores que se consideran amantes de los cuadros de época $(1978 ; 7)$ ". De tal suerte, como aquí bien lo muestra Dumas, podríamos señalar que la historia al interior de las obras literarias podría ser asumida en ese doble juego de lo verídico y lo posible; no obstante es pertinente señalar que lo primero atañe a eso que otrora llamábase historia objetiva, mientras lo segundo cae bajo el poder del saber literario.

\footnotetext{
21. Esta concepción del saber de la historia con un tinte subjetivo puede verse, en el ejercicio de tal saber en Colombia en la obra de Germán Arciniegas a diferencia de la de Henao y Arrubla. Este intento por construir una historia un poco más afín al hombre comienza a bosquejarse en Colombia a finales del siglo XIX. En la poesía de José Asunción Silva se lee: (...) No guarda su memoria / de la ventana la vetusta historia / y sólo en ella fija / la atención el poeta $(1998 ; 57)$.
} 
No es un sesgo de mirada lo que en este lugar se propone. Lo que procuramos, no hay que olvidarlo, es la construcción fiel al sentido del "concepto" de novela histórica, es decir a la relación entre historia y literatura. Es bien cierto que el concepto y con ello la disciplina de la historia se han abierto, podríamos decir que, decididamente, desde mediados del siglo anterior hasta nuestros días no sólo al estudio minucioso de los hechos, sino también a la interpretación de los mismos, a la observación del punto de vista del narrador y, por ende, se descree ahora de una visión total y omniabarcante, objetiva y fría del suceso histórico; no obstante, ello no ocurre así en una época diferente a la nuestra, no tan lejana en el transcurso del tiempo.

De tal suerte que bien podríamos decir, siguiendo a Amado Alonso que, con la construcción minuciosa de cada uno de los resquicios de un hecho histórico al cual nos avoca la imaginación y no la prueba, aspiramos a reconstruir el "espíritu de una época"; Amado Alonso lo expresa de la siguiente manera: "Empezando por Walter Scott, son muchos los novelistas de este género, ingleses, franceses, alemanes, italianos y españoles que declaran explícitamente como finalidad de sus invenciones el representar el "espíritu de una época" pretérita" (1942;49). ${ }^{22}$

Obsérvese que aquello a lo que el profesor Amado Alonso ha denominado "finalidad", es lo que entendemos en la presente indagación como objeto. Ello se hace de tal manera en tanto que, a diferencia del profesor Amado, entendemos que la finalidad que persigue un texto es susceptible de interpretación por parte del lector, no obstante sucede algo diferente con el objeto de la novela histórica, este se muestra en cada línea que el autor construye.

En consonancia con lo anterior debemos recordar que el tipo de narración que encontramos en las novelas históricas tiene una fecha de nacimiento. Es ya el propio Walter Scott, a inicios del siglo XVIII quien ha marcado la pauta para encontrar una narración que presente un entrelazamiento de nuevas emociones y sentimientos teniendo como marco escenográfico un suceso histórico. Pero no sólo encontramos allí al escritor de Rob Roy, acompañándole nos topamos con el admirador de Napoleón y hacedor de Rojo y negro; no hay que olvidarlo, también encontramos entre los exponentes de este género al muy humano escritor de Los miserables y, de igual forma, el inventor de Los tres mosqueteros. En ellos prima el

22. Es de común consenso que los escritores más notorios de ese género o subgénero como algunos quieren llamarle, no han dejado de ser Walter Scott y Alejandro Dumas. Así parece reconocerlo el escritor cartagenero Germán Espinosa quien, por efectos de su autodidáctica formación, admirable por lo demás, ha pensado que es lo mismo una novela histórica que una novela con trasfondo histórico. Debe recordarse que entre estas últimas bien podrían caber las llamadas nuevas novelas históricas. Para observar la posición del escritor en cuanto al tema véase por ejemplo su Ensayos completos (2002; 57-60). 
relato en referencia al suceso histórico de un pueblo determinado sin por ello, por la limitación geográfica que la narración impone, caer en el más profundo de los provincialismos.

Hasta el punto que hemos llegado podríamos señalar que nuestro propósito se ha agotado y, no obstante, pese a haber señalado que el objeto de la novela histórica es la reconstrucción del espíritu de una época, ha faltado algo por esclarecer. Ese algo es simplemente una contemplación de lo ya dicho. Se ha señalado la existencia de un género de narraciones que se ha denominado novela histórica, pero lo cierto es que, como género, la palabra desconoce unas variantes que son necesarias al momento mismo de llevar a cabo una indagación.

Entre estas variantes el profesor Amado Alonso apunta la siguiente. "Mientras la novela histórica romántica languidecía en todas partes, renovaron el género escritores de fuerte personalidad impulsores del realismo literario" (1942;49). Así pues, observamos con la ayuda del profesor Amado que hay dos tipos de novela histórica, la novela histórica romántica y, como su heredera, la novela histórica realista. Entre estas últimas, el profesor amado cataloga a Salamboo de Flaubert en la cual se relata una historia recurriendo a una ardua datación de la época, el año 241 a. de $\mathrm{C}$, que raya casi con la información del especialista.

Y aquí no acaban las divisiones concernientes a la novela histórica, Lukács hace también lo propio.

La antigua novela histórica clásica fue histórica en cuanto que ofrecía una concreta prehistoria del presente, en cuanto que plasmaba la evolución del pueblo a través de las crisis del pasado hasta llegar al presente. También la novela histórica de los humanistas contemporáneos mantiene un estrecho vínculo con el presente, y en este sentido ha superado ya el periodo de decadencia burguesa, e incluso se encuentra en radical oposición a ella $(1971 ; 371)$.

Puede decirse que mínimamente aparecen en Lukács dos tipos de novela histórica, la clásica y, sumada a ella, la humanista. Debe anotarse que, en relación al mismo asunto: La primera se encarga de reconstruir palmo a palmo el suceso histórico hasta situarnos en nuestro tiempo; la segunda reconstruye el desarrollo de los ideales propuestos por la modernidad (la Ilustración) como estrategia política en confrontación con el antiguo régimen monárquico.

Cabría así la objeción de que si bien ello se encuentra depositado en la literatura sobre la novela histórica aún no se ha aportado alguna evidencia de lo que ella sea 
para Gómez Valderrama. Pues bien, la novela histórica ha llegado a manos de Gómez Valderrama a través de la mirada de Lukács pero, igualmente a través de la lectura de Scott, Dumas y Stendhal. Así puede mostrarse en esa intervención retomada en la Antología cuando el creador de Invenciones y artificios señala:

Ciertamente la novela histórica nace en las postrimerías del siglo XVIII, $\mathrm{y}$ tal vez sus antecedentes fueron la reescritura de la historia antigua y de los mitos medievales. Pero solamente en el siglo XIX los personajes proceden de la específica característica histórica de su tiempo $(1995 ; 193-4)^{23}$.

Una vez mostrada una panorámica general acerca de la novela histórica, una panorámica en la que magistralmente se implica el escritor de La otra raya del tigre, pero haciendo caso omiso de tales taxonomías en tanto que ya preestablecidas por algún escritor y optando por unir ambos tipos de relato, el de la literatura y el de la historia en una sola, comenzaremos a definir algunas características que han de completar el significado del "concepto" de novela histórica. Para ello nos hemos valido, como ya lo habíamos mencionado de dos subtemas: objeto de la novela y relación con la verdad de hecho. Comenzaremos entonces dando alguna luz sobre el primero de los temas señalados

\section{Objeto de la novela histórica:}

Es ahora, una vez discutido el término novela histórica, que se hace necesario complementar el conocimiento que tal expresión indica designando un par de cualidades que vienen de suyo. Iniciaremos este recorrido buscando cuál es el objeto que dichas narraciones, las novelas históricas, persiguen. Hemos sostenido anteriormente que ya no es posible pensar el asunto de la novela histórica sin antes citar a un grande, $\mathrm{y}$ al hacerlo hemos invocado nuevamente su nombre adjuntando una amplia cita que ha quedado líneas atrás sin su merecido comentario (supra; 30-31). Es el momento entonces, después de haber realizado el esclarecimiento pertinente sobre el término novela histórica, de llamarlo, de dejar que hable quien más sabe; Lukács ha dejado marcado el camino acerca del objeto que persigue una novela histórica. Al señalar dicho objeto no sólo indica el entorno sobre el cual gira la cuestión, designa con ello, también, eso que importa en la conformación misma de la novela histórica. En primerísimo lugar debemos señalar que el objeto de este tipo de novelas, aquello hacia lo cual tiende, como meta final o como asunto esencial

23. Para observar la relación entre la postura de Pedro Gómez Valderrama y la de Lukács ver las páginas 187 y 192 del mismo texto aquí citado. Ahora bien, si lo que se quiere es mirar una especie de biografía intelectual en la reconstrucción espiritual del mismo género, la novela histórica, debe mirarse lo señalado por Gómez Valderrama en la página 177. 
de la misma, no puede ser otro que el de describir la particular configuración de un fenómeno histórico en detrimento de un sinnúmero de acontecimientos anotados sin una elaboración detenida. Ello lo podemos observar en ese aparte tan extenso que citábamos anteriormente en donde nos señala Lukács tomando como referencia la crítica elaborada por el escritor de Eugenia Grandet que "La novela entera -Leo de Latouche- sólo consta de 200 páginas en que se tratan 200 acontecimientos; nada revela mejor la incapacidad del autor que la acumulación de hechos..." (1971; 44). Aquí lo que nos indica el discípulo de Marx dedicado en esta ocasión al análisis literario de una manera indirecta, al recurrir a las palabras de Balzac, es que el quid de la crítica a la novela Leo de Latouche, consiste en que la virtud de la novela histórica no tiene por objeto último el hallar la correlación entre hechos narrados literaria e históricamente, sino el hecho mismo de describir el origen fundamental de cada suceso histórico recreando lo que los personajes pudieron haber albergado en su corazón; es esto lo que realmente importa para el literato lejos de la correspondencia con el saber datado entre los enunciados de los anales históricos y el relato que ejerce la literatura. Así mostrado no podemos decir que el objeto de la novela histórica sea únicamente la narración de hechos sin más, la información acerca de los mismos, su objeto, no es la "acumulación de hechos", sino más bien la elaboración de tales sucesos por parte de quien los narra, es allí en donde se hace evidente el talento del narrador. Lukács señala en la misma indicación que: "El talento florece cuando se describen las causas que provocan los hechos, florece en los misterios del corazón humano, cuyos movimientos descuidan los historiadores" $(1971 ; 44)$. Con ello tenemos que lo narrado, más que un simple acontecimiento histórico, es la descripción de los motivos ${ }^{24}$ que detonan esos hechos, sucesos que también podemos hallar tranquilamente, pero de una manera más objetiva, es decir, olvidando lo esencialmente humano del asunto, al abrir un manual de historia.

Este objeto de la novela histórica, nos lo confirma posteriormente el propio Lukács, cuando lo señala de la siguiente manera: "así pues, de lo que se trata en la novela histórica es de demostrar con medios poéticos la existencia, el "ser así" de las circunstancias históricas y sus personajes" (1971; 45). Cuando Lukács nos habla de la "demostración" con medios "poéticos", del "ser asî" de las circunstancias de una época histórica nos narra, en realidad, un evento sumamente importante en la composición de la novela histórica, el asunto de que se nos describa un hecho que ha sido datado por el "frío" saber de la historia, reducido de una forma tradicional

\footnotetext{
24. Entiéndase por motivos aquellos argumentos morales que justifican o no una acción. Así lo propone Sartre cuando afirma: "se entiende por motivo la razón de un acto, es decir, el conjunto de consideraciones racionales que lo justifican. Si el gobierno decide una conversión de las rentas, dará sus motivos: disminución de la deuda pública, saneamiento de la Tesorería. Igualmente por motivos suelen los historiadores explicar los actos de ministros o monarcas" $(1966 ; 551-2)$.
} 
a nombres, hechos y fechas, pero, en esta ocasión, narrado desde una óptica muy peculiar, engalanado con "medios poéticos".

La pregunta que no se hace esperar no puede ser otra: ¿en qué consiste la peculiaridad de la visión sobre el apunte histórico que hemos señalado, el cual conforma la contra parte de la narración que contiene la novela histórica? Al señalar qué es una novela histórica, descubriendo su objeto de estudio, entendiendo este como el relato pormenorizado, finamente detallado, de un acontecimiento cualquiera, indicamos que la relación existente del asunto de la novela histórica con la verdad de hecho puede dividirse en dos temas a saber: la verdad literaria y la verdad histórica. Ello se hace de tal modo en la medida en que nuestro objeto de estudio es la novela histórica; ella, por su sólo nombre, participa de dos géneros diferentes como ya lo hemos señalado: novela e historia.

Al parecer la cuestión diferencial entre la novela histórica y la historia en cuanto a su objeto no obedece más que a un asunto de carácter "formal", en otras palabras a la manera de expresión en el mecanismo atinente a la transmisión de ideas. Así configurado el problema, este no es meramente "formal", lo trasciende. Cuando hablamos de una forma más poética en lo atinente a la expresión de la novela histórica estamos señalando una relación vividísima con la historia a diferencia de la relevancia del mero hecho que no nos entrega más que una información del acontecimiento, echando al olvido que esos acontecimientos son productos de actos volitivos de esos seres de un día (los humanos) que nos han precedido en el curso de esta existencia.

Esto se ve confirmado en el texto de Lukács, páginas más tarde, cuando nos señala la relevancia que para él tiene la particularidad de los seres históricos. Lukács nos dice

la interesante y difícil tarea de la novela histórica consiste precisamente en representar de tal modo lo significativo del "individuo histórico" que no se relegue a un segundo o tercer plano el cúmulo de los acontecimientos capilares y complejos de la evolución social de la época, sino que, por el contrario, los rasgos sobresalientes del "individuo histórico" surjan orgánicamente de esta evolución y expliquen a la vez esta misma evolución, la hagan conciente y la eleven a un estrato superior $(1971 ; 140)$.

El papel de lo que aquí se denomina "lo significativo" no es más que, precisamente, la descripción de eso que es sumamente ínfimo y que, al tiempo, conforma la existencia del "individuo histórico", siendo que las vivencias particulares de dichos individuos, portadores de la égida histórica, nos conducen a descubrir ese 
complejo que aquí se denomina como "la evolución social" en el instante mismo en que, mediante la descripción particular de los acontecimientos, hacemos consciente dicha transformación social, una transformación que no tiene otro nombre más que el de progreso.

Ahora bien, por último, encontramos en una auténtica novela histórica la idea de progreso. Esta idea proveniente de una etapa de la humanidad en que el auge científico-técnico manifestaba ser la ruta de salvación de las existencias, se fosiliza en la novela histórica. Así parece relatárnoslo Walter Scott cuando nos dice "El problema central en que se expresa el cambio de posición frente a la historia es el de progreso" (citado en Lukács, 1971; 210). Así pues, más que ser este un término carente de significación, lo que trae de suyo no es más que la modificación de una perspectiva en torno a algo que ya ha dejado de ser un ahora para convertirse en un fue. Esa idea del progreso nos habla de un estado que sucede al otro en pro de un acomodamiento, de una, si se quiere, adaptación a nuestro entorno, a nuestra forma de percibir la vida. No es gratuito que este término se promocione en medio de la filosofía historicista del pensador de la Fenomenología del espíritu; lo que eso nos indica, es que en cierta manera hay una relación con un fin último hacia el cual tiende, siendo que en el camino hacia la obtención de ese fin, es donde hallamos depositada la idea de progreso, de cambio, es decir, de contradicción entre lo que es y el fue, vaticinando un será, que es ignoto para nosotros a cabalidad, pero del cual tenemos, apenas, pálidas nociones.

Pero es en ese confín de lo ignoto que se nos muestra un derrotero para nuestra existencia, el saber acerca del fue y del es. Así comprendido el tema del progreso al interior de la novela histórica, como una comprensión de nuestra situación histórica que hace énfasis en el pasado, aporta una gran cuota en cuanto que ella misma se torna una buena herramienta al momento mismo de hablar acerca de un progreso humano; así, en cuanto herramienta de progreso, la novela histórica tiende a: "(...) restablecer en su realidad estos móviles auténticos de la historia humana y despertarla a la vida para el presente" (Lukács, 1971; 398) con lo cual se comprende no solo la datación, el suceso de lo ya acaecido, sino, de igual manera, los motivos que llevaron al aparecimiento de dicho suceso para aprender de ello algo realmente útil para nosotros.

\section{Relación con la verdad de hecho}

Como hemos observado hasta el momento, sólo se ha hablado del objeto de la novela histórica, ahora nos corresponde abordar el segundo punto que hemos señalado: la relación existente entre la verdad de la historia y la verdad literaria. Para ello es necesario señalar que la verdad de la historia se encuentra delimitada por la 
correlación entre el suceso histórico y el testimonio que nos deja el mismo ejercicio de escritura literario. En el aparte principal que hemos señalado como el derrotero de nuestra indagación, la extensa cita que aparece en la página 26 de este texto, se nos señala que “(...) Las personas de una novela se ven forzadas a ser más racionales que las personas históricas. Aquellas deben despertar a la vida, estas han vivido." (1971; 44). Con ello se nos dice simplemente que los caracteres de las personas que hemos asumido como los personajes de las obras y que al tiempo corresponden, en su mayoría sino en su totalidad, a individuos históricos, no pueden corresponder de lleno a la verdad histórica, deben superarla en cuanto a sus contenidos de racionalidad. Ello en la medida que el signo bajo el que se encuentra elaborado no es otro que la parca práctica de la escritura; no es una vivencia como tal, es el retrato de esa vivencia conversa a palabras, un retrato que, como la obra de arte visual o sonora, debe despertar esa sensación en nosotros de ser tan real que incluso la podamos palpar como la más vívida de las sensaciones.

No obstante hay una salvedad que se introduce posteriormente: “...La existencia de estas no requiere pruebas, por curiosos que hayan sido sus actos, mientras que la existencia de aquellas necesita de un general consenso" (1971;44). Estas palabras se pueden entender si pensamos que la relación entre la verdad histórica y el ejercicio literario debe estar mediado por un mínimo conocimiento de la historia misma, es decir que se debe respetar un mínimo de lo que conocemos consensualmente sobre un hecho histórico. La cuestión pues de la fidelidad a la verdad histórica no se queda meramente en la plasmación de unas condiciones sociales y políticas que son posiblemente inalterables en el decurso de la historia misma, ella toma como derrotero fundamental exponer cuál es la necesidad histórica del momento; pone de manifiesto, de igual manera, ese impulso vital que lleva a los seres humanos en su pluralidad a modificar su forma de vida en favor de otra.

Observemos como describe el problema Celia Fernández Prieto cuando señala, haciendo una acotación sumamente precisa sobre la relación entre la verdad de hecho y la verdad de la historia que

Scott traza, pues, los pilares básicos del género y señala implícitamente cuál es el pacto narrativo que se propone al lector: son composiciones de ficción cuya acción se localiza en un periodo concreto del pasado nacional en las que acontecimientos y personajes de cuya existencia está documentada históricamente, se mezclan con personajes y acontecimientos inventados. Pero no debe esperarse una fidelidad histórica rigurosa pues el escritor de ficciones goza de ciertas licencias que le permiten actualizar el pasado para hacerlo inteligible a los lectores contemporáneos y para despertar así el interés de este hacia la historia $(1998 ; 85)$. 
Así, como puede observarse, la necesidad de ficción ${ }^{25}$ en la novela histórica se justifica en la medida en que es necesario hacer comprender al lector moderno una realidad sicológica que, de cierto modo, le es ajena, y para ello hay que procurar colocar a ese lector en una situación muy parecida a la que hubo de darse en la frontera del espacio y el tiempo que la novela histórica pretenda narrar. De hecho, la mera reproducción de las condiciones socio-económicas de una época pasan a ser meramente "detalles" y no cuestiones eminentemente fundamentales, los cuales “...no son más que medios para alcanzar verdaderamente la mencionada fidelidad histórica" (Luckacs, 1971; 67).

Así expuesto lo que interesa en la novela histórica no es tanto la fidelidad al hecho sino al sentimiento que ha conducido al hecho. Desenmarañar las angustias de los individuos históricos a través del ejercicio coleccionista de recrear un ambiente cultural, una época determinada, o lo que posteriormente denominaremos cosmovisión es, sin lugar a dudas, lo que nos seduce de la lectura relativa a una novela histórica. En ella lo histórico, la juiciosa descripción de los detalles, no es más que un ejercicio a través del cual podemos captar un sentimiento, lo verdaderamente importante de aquello que mueve una época determinada, su pasión por practicar ciertas costumbres, el empeño en lograr ciertos ideales, las fronteras de sentido hacia las cuales tiende. Todo lo anterior, en conjunto, no hace más que seducirnos al tiempo que nos ilustra sobre una época determinada.

Elucidar el saber de la novela histórica de esta manera, como una reconstrucción que alude a una época histórica, tiene una implicación un tanto peligrosa. Dicha implicación nos señala que el saber que encierra la novela histórica es un saber completamente objetivo, es decir que quien narra lo acontecido dentro de la novela no puede, haciendo gala de su capricho, modificar la situación histórica narrada a su amaño. Dicha objetividad se da en tanto que debemos desprendernos de las circunstancias que conforman nuestra época para poder configurar aquellos otros detalles que son propios de una época particular; así entendido el problema, debemos realizar un ejercicio muy semejante al del saber hermenéutico para comprender el sentido de una época, asumiendo cada uno de sus detalles con el fin de reconstruir el sentimiento. Así parece evidenciarlo una vez más la profesora Prieto al recordarnos citando a Apud Allison Peers que

Es necesario colocar al lector en medio de la sociedad que se pinta; es necesario que la vea, que la oiga, que la ame o le tema, como ella fue con

25. La palabra ficción, es proveniente para nuestra lengua española del latín fictǐo, ōnis y ella designa en la lengua latina la capacidad de inventar, de formar, una capacidad que es potestativa del ser humano. Señalar los límites de tal ficcionalidad en el género correspondiente a la nueva novela histórica es lo que aquí se propone. 
todos sus defectos y todas sus virtudes. Los sucesos y aventuras pueden ser fingidos pero el espíritu de la época y sus formas exteriores deben describirse con suma exactitud. En este sentido no hay autor más clásico que Walter Scott $(1998 ; 97)$.

En cuanto a este ideal de la objetividad que inunda la narración en la novela histórica hallamos lo siguiente: "Es obvio que cuanto más alejado se halle un periodo histórico, con las condiciones de vida de sus actores, tanto más se tiene que concentrar la acción en presentarnos clara y palpablemente esas condiciones de vida" (Lukács, 1971; 67). Es de esta manera, al tener una distancia histórica, y asumir tal distancia objetivamente de forma diferente a nuestra condición actual, como puede darse a entender la correlación entre el hecho histórico y la narración literaria como un suceso en el cual la objetividad se hace manifiesta. Bajtín, en esta dirección ha consignado una frase lapidaria que puede, como toda frase que lleva consigo esta característica, esclarecer de un tajo el problema: "Para entrar en la historia hay que dejar de ser uno mismo" (1991; 29). Lo que debemos preguntarnos, entonces, es lo siguiente ¿Cuál es el fin de dicha objetividad, de ese alejamiento de nuestra subjetividad en relación a la comprensión del fenómeno histórico? La finalidad hacia la cual tiende, al colocar el hecho narrado distante de nuestra subjetividad, no puede ser otra "que no miremos la peculiar psicología y ética resultante de estas condiciones como mera curiosidad histórica, sino para que revivamos una etapa del desarrollo de la humanidad que nos interesa y nos conmueve" (Lukács; 1971;67). Así entendido el fin de la novela histórica que se conjuga en su relación con la verdad de hecho no puede ser otro que el de quedar subsumidos en el campo de la estética, entrar en su juego, hacernos partícipes de él. En dicho alejamiento de nuestras circunstancias actuales entran en juego sentimientos tales como el del recuerdo y la añoranza que le entregan ese toque poético y que es, en esencia, lo puramente subjetivo del ejercicio escrito para compenetrarnos con esa verdad de hecho que es histórica ${ }^{26}$ (cfr. 1971; p. 287).

Hasta este punto hemos abordado sólo un par de caracterizaciones que circundan la novela histórica. Así mostrado, aquello que se evidencia tras elaborar el objeto de la novela histórica, comprendido este, no como el hecho histórico, sino como la reconstrucción de un espíritu epocal de una instancia histórica, tenemos, al tiempo, que aquello que se pone en riesgo en las novelas históricas no es más que

\footnotetext{
26. Pese a lo consignado aquí acerca de la distancia en la narración del hecho histórico como condición para la objetividad existen diferentes posturas frente al tema. El profesor Solanilla señala que "no siempre es indispensable la "toma de distancia” muy larga en el tiempo para convertir la realidad casi inmediata en ficción” (2008; 198). Sí, es cierto, para ficcionalizar un hecho no es necesaria la toma de distancia, pero sí lo es para acometer el esfuerzo de forjar, en el pleno sentido de la palabra, una novela histórica.
} 
el asunto de la fidelidad histórica, es decir, de la correspondencia entre el saber de la novela histórica y el hecho histórico como tal. En la novela histórica como lo pudimos observar, dicha discusión ha quedado un tanto superada al señalarse una referencia a la comprensión de un fenómeno histórico en una forma determinada y no como se ha registrado en la escritura que nos dejan los testimonios de la historia. La fidelidad estará dada no sólo por la breve concordancia entre la escritura literaria y la escritura historiográfica, sino también por el hecho mismo de que nos sean relatadas las condiciones que forjaron ese espíritu epocal que ha contribuido a la aparición de dicha manifestación histórica; a esta relación Lukács la denomina con la palabra necesidad. Así pues la fidelidad histórica del saber literario en la novela histórica se encuentra mediado por la correcta descripción de las necesidades de la época más allá que de los propios hechos. Para ello cabe anotar que tal identificación no se ejecuta si se carece de lo que hemos denominado aquí, líneas atrás, una conciencia histórica ${ }^{27}$. Así parece plantearlo la señora Prieto cuando afirma:

Una novela histórica sólo llega a serlo cuando el lector identifica a algunos de sus componentes básicos como "históricos". Para ello hace falta, entre otras cosas, la adquisición de una conciencia histórica tal y como se forja a partir del siglo XIX, una conciencia de la temporalidad y de la ruptura entre el pasado y el presente de la que carece la novela griega $(1998 ; 46)$.

Aquí, en efecto, tal y como aparece en la cita, se ha de decir que la novela histórica requiere como condición previa de una conciencia histórica al momento de ser abordada; no obstante, es preciso señalar que en la función poética del lenguaje, aquello que hace la novela histórica con su forma de narrar es exhortarnos a una conciencia histórica. Con todo lo anterior queremos indicar que el saber literario del que hace gala la novela histórica más que elaborar un acopio de la datación sobre la historia, asumida en tanto que objetiva como un discurso sin alma, lo que busca es simplemente llevar a cabo una relación un poco más humana de lo que dichos acontecimientos fueron, siendo que la historia, como lo indica Jaspers es el más humano de los saberes (Cfr. 1978; 87-88).

Cabe recordar que estamos abordando el problema del género en la literatura y que el rastreo elaborado hasta aquí es de carácter formal. Al establecer como puntos centrales de la construcción del "concepto" de novela histórica el objeto que persigue y su relación con la verdad de hecho no nos hemos preocupado directamente de los contenidos de la misma. En cuanto a estos elementos que corresponden a aspectos formales baste mencionar, a parte de la ya citada idea de progreso, otros dos 
elementos: el castillo y los caminos. En relación al primero Bajtín anota:

La historicidad del castillo ha posibilitado que el tiempo represente un papel suficientemente importante en la evolución de la novela histórica. El castillo procede de los siglos pasados, y tiene vuelta la cara hacia el pasado. Es verdad que las huellas del tiempo tienen en él un cierto carácter de cosas de museo, de anticuario. Walter Scott logró superar el peligro de quedarse en eso, orientándose preferiblemente hacia la leyenda del castillo, hacia la relación del castillo con el paisaje entendido e interpretado desde el punto de vista histórico. La fusión orgánica en el castillo (con sus alrededores) de los momentos-rasgos espaciales y temporales, y la intensidad histórica de este cronotopo, han determinado su productividad plástica en diferentes etapas de la evolución de la novela histórica (1991; 396-7).

Como bien puede observarse este cronotopo, elemento espaciotemporal, de la novela histórica se erige como un fuerte indicio de la historia anclado entre dos tierras: el mundo feudal y el moderno mundo burgués; el castillo se erige en la novela histórica como un monumento, como un rezago de la memoria cuyo fin último es, como ya lo habíamos señalado de la novela histórica en general, fortalecer una conciencia histórica a través de la reconstrucción de un espíritu de época.

Otro elemento que es potestativo de la novela histórica es el, o mejor, los caminos. Toda novela histórica, en palabras de Bajtín, posee este cronotopo. Bajtín señala: "Finalmente la significación del camino y de los encuentros en él se conserva en la novela histórica: en Walter Scott y, especialmente, en la novela histórica rusa" (1991; 395). Así, no sólo el elemento de los caminos sino, también como lo señala Bajtín, de los encuentros en ellos, es un factor que constituye como tal a la novela histórica. De tal manera, a nivel formal, observamos que esta "máscara", este género literario que un escritor toma, posee unos elementos formales que hacen de tal máscara algo susceptible de definición y, al tiempo, de meditación al momento mismo de encarar la lectura de una novela histórica. 


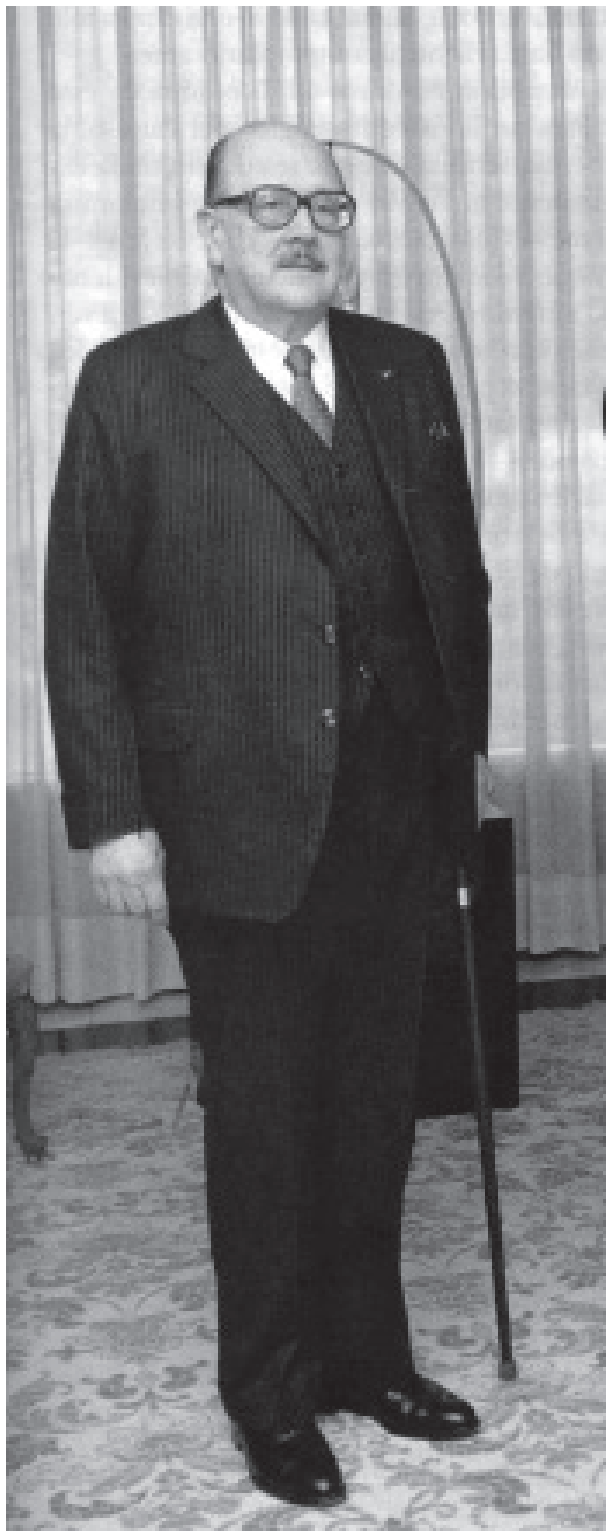

Imagen tomada de la revista de la Universidad de Antioquia

(2006; Abril-Junio) Número 284 p. 97 
CAPÍTULO DOS 


\section{Apuntes para la comprensión del "concepto" de nueva novela histórica}

Una vez abordado el tema de la novela histórica es necesario que ahora hablemos de la nueva novela histórica. Ella, como descendiente del género literario que en el capítulo anterior hemos acotado, tiene algunas características que la hacen similar pero no igual a tal género, la novela histórica. Es necesario que, siguiendo el esquema que hemos indicado para la indagación sobre la novela histórica, observemos aquí también la relación que teje esta con temas tales como el objeto de la novela y la vinculación con la verdad de hecho. No sin antes dar una descripción del surgimiento del mismo género. Cabe señalar que la brevedad del presente capítulo se justifica en haber elaborado ya previamente, un acercamiento por separado a los términos novela e historia

En este aparte, tal y como lo hemos cifrado con antelación, esperamos dejar claro, respecto a los parámetros señalados (objeto de la novela y vinculación con la verdad de hecho), dos tópicos fundamentales que conforman una nueva novela histórica. En primer lugar debemos sostener que tal y como Menton nos lo relata, la novela de Gómez Valderrama, La otra raya del tigre, por la fecha de su aparición, debería haber estado incluida en tal categoría y, pese a esto, no es de tal modo, aspecto que de entrada ya sugiere una conciencia en la elección del género literario por parte del autor. En el Prepéndice de su libro, La nueva novela histórica, Menton sostiene que dichas nuevas novelas históricas han sido publicadas en un periodo de tiempo que establece el año de 1942 como fecha inaugural y que se extiende, hasta donde su estudio llega, al año de 1992. Por el momento baste recordar que la novela de Pedro Gómez Valderrama es simplemente de 1977 y que su elaboración, como su mismo autor lo indica, se encuentra enmarcada en las fechas de "febrero 7 de 1973, diciembre 30 de 1976" (Gómez Valderrama, 2003; 391).

Antes que proceder a vincular la obra señalada de Gómez Valderrama con un género literario, la pregunta que debiéramos hacer es la siguiente: al fin de cuentas ¿Qué es eso que denominamos aquí nueva novela histórica? Una vez establecida que ha sido la novela histórica en el sentido clásico de la palabra, debemos señalar que la nueva novela histórica no es más que un relato que, a partir de un determinado suceso o personaje no necesariamente histórico, pero que si establece una relación con algún otro personaje de la historia, construye una narración que en la totalidad de las ocasiones limita con la fantasía. Así, este cortejo del predominio de la ficción amalgamada con el espíritu literario es lo que da pie al surgimiento de la nueva novela histórica. 
No obstante, la definición otorgada opera meramente como noción sobre lo que hasta el momento se ha señalado. Ello lo hace en la medida en que tal noción no pretende ahondar sobre el asunto y, al hacer esto, produce sólo una presentación general del problema. Habría que precisar que para poder ejecutar una consulta sobre aquello que sea la nueva novela histórica es imposible, como ya lo pudo constatar el lector, no hacer referencia a Seymour Menton. Este escritor es el que se ha encargado fundamental y casi que exclusivamente de caracterizar a plenitud lo que nosotros denominamos aquí el "concepto" de nueva novela histórica.

Una muestra de ello, de una caracterización teórica, con arduo rigor, es la que veremos a continuación. Menton señala, recurriendo a categorías literarias planteadas por Bajtín que, en la nueva novela histórica aparecen:

a. Lo bajtiniano, es decir lo dialógico, lo heteroglósico y lo carnavalesco.

b. La intertextualidad.

c. La metaficción o los comentarios del narrador sobre la creación de su propio texto.

d. El protagonista histórico.

e. La distorsión consciente de la historia por omisiones exageraciones y anacronismos.

f. La subordinación de la reproducción mimética de cierto periodo histórico a conceptos filosóficos trascendentes (1993; 274-5).

De esta manera puede verse que lo que ofrece Menton como categoría narrativa no obedece a ninguna tipificación a ultranza o de mera opinión subjetiva. Tras dicha taxonomía, la de nueva novela histórica, se revela la existencia de un estudio fundamentado de manera conceptual en un gran aparte de la teoría de Bajtín sobre la novela. Hay que anotar, para salvaguardar la valiosa cita de Menton, que el compendio de las categorías bajtinianas entregadas como momentos de tal definición, no pueden leerse como un decálogo en donde la ausencia en el cumplimiento de tan sólo una de estas categorías indique el distanciamiento o, mejor, la pérdida de la categoría de nueva novela histórica a un relato. A continuación haremos un breve repaso de las características anunciadas por Menton como confortantes de una nueva novela histórica y con ello de su significación al interior de la reflexión de Bajtín.

Cuando Menton habla de lo bajtiniano de una novela entiende por ello lo dialógico, lo heteroglósico y lo carnavalesco. Debe señalarse entonces que lo 
dialógico en Bajtín es aquella cualidad que tiene una obra literaria de entrar en comunicación con las diferentes comunidades que componen una sociedad. Así lo dialógico pronto irá a desembocar en el análisis literario en aquello que se manifiesta como una palabra bivocal, es decir, una palabra que admita la réplica del otro; una palabra que no se quede en el discurso narrado desde una sola voz y por lo tanto no es partícipe de un relato que pretenda la construcción de un mundo unívoco, para así, escapando a esa univocidad y anclándose en la pluralidad dicha palabra construya lo dialógico de la novela. A propósito de esta categoría, se lee en Bajtín:

Cada momento del relato está relacionado con ese lenguaje normal y con ese horizonte; les es opuesto, además, de manera dialogística, como un punto de vista opuesto a otro punto de vista, como una valoración opuesta a otra valoración, como un acento opuesto a otro acento (1991; 131-2).

Así, al oponer dos puntos de vista, al entregarse al juego, por decirlo de alguna manera, de las antinomias kantianas (Cfr. Kant, 1998; B448-490), es decir, sin elevar ninguno de los dos puntos de vista acerca de una situación dada por el narrador o el focalizador a la categoría de absolutamente verdadero, es que puede establecerse el dialogismo en la novela.

Ahora detengámonos en el análisis de lo heteroglósico de la novela. La palabra que aquí se menciona, heteroglósico, para designar una cualidad de las narraciones literarias indica que hay en ella otras (hetéro) lenguas (glos) que caracterizan (ico) un discurso. El aparecimiento de esta característica, lejos de tomar a la lengua como el compendio de signos y fonemas que conforman una manera de hablar de un pueblo determinado, toma a la lengua como el modo de hablar de diferentes personas que no necesariamente tienen que distanciarse por la barrera del idioma; lo heteroglósico en la novela indica un lenguaje que no es unívoco, es decir, que no posee un solo sentido al existir diferentes hablantes que confieren sentido a las disímiles expresiones que conforman un solo idioma. Ello, la cualidad de que el lenguaje tenga su propio valor para el hablante, es aquello que hace pensar en diferentes glosas, es decir, en un cúmulo de formas diferentes de comprender el mundo vueltas lenguaje.

En cuanto a la intertextualidad un texto perteneciente a la nueva novela histórica dialoga con personajes y textos de otras creaciones literarias que no necesariamente son históricos. Acerca de este tópico Fernando Aínza señala: "La historicidad del discurso ficcional puede ser textual y sus referentes documentarse con minucia o, por el contrario, la textualidad revestirse de las modalidades expresivas del historicismo a partir de una "pura invención" mimética de crónicas y relaciones" (1991; 84). 
Así pues, las relaciones que se tejen con otros textos, el citado diálogo intertextual, no es fácilmente datable y obedece, en la mayoría de las ocasiones a la "pura invención" del escritor.

Se encuentra también en este tipo de relatos que configuran la nueva novela histórica la categoría bajtniana de la metaficción. Ella hace referencia a un comentario ejecutado por el mismo narrador del relato sobre la propia obra de la cual él es participe ya como personaje o como testigo presencial que narra el acontecimiento. En dicha narración se describe el proceso de elaboración de la novela, las fuentes que ha tomado para ella, los testimonios recopilados o simplemente la selección de personajes, dicho proceso que se encuentra ausente de la mayoría de novelas históricas se ve en este texto de una manera palpable. Así, en Respiración artificial de Ricardo Piglia se lee justo al iniciar su texto: “ ¿Hay una historia? Si hay una historia empieza hace tres años. En abril de 1976, cuando se publica mi primer libro, él me manda una carta, con la carta viene una foto donde me tiene en brazos (...)" (1993; $11)$.

Así, como lo muestra Piglia, la recolección de datos con los cuales se ejecuta la narración, lo que podríamos llamar aquí lo metaficcional entra a jugar en esa ardua trama de la novela.

En el caso de esa otra categoría que anuncia Bajtín a través de Menton, el protagonista histórico, ya lo habíamos mencionado, no necesariamente es el heraldo de la historia. En otras palabras lo que aquí se quiere señalar es que la nueva novela histórica no se centra fundamental y exclusivamente en ese ser humano de relevancia histórica capital en un acontecimiento dado, sino que bien puede hacerlo en alguien que ha compartido ese instante cronológico con el individuo histórico sin que fundamentalmente este acompañante haya existido.

En la distorsión histórica consciente hallamos un juego con los contenidos de la misma historia. Así parece anunciárnoslo el propio Aínza cuando indica como característica de esta nueva novela histórica: "La re-lectura distanciada, "pesadillezca" o acrónica de la historia que caracterizan esta nueva narrativa se reflejan en una escritura paródica" $(1991 ; 85)$. Así entendida, la historia pasa a ser el llamado telón de fondo de la nueva novela histórica. Ya no hay aquí una sustancial preocupación por la reconstrucción de un espíritu de época, se procura en su lugar un juego con los contenidos de la cultura.

Finalmente la última categoría que aquí Menton propone es, como ya lo anotábamos, "La subordinación de la reproducción mimética de cierto periodo histórico a conceptos filosóficos trascendentes" (1993; 275). Esta categoría que como tal se anuncia compleja bien puede explicarse a través de una re-lectura de los 
acontecimientos registrados por la historia desde una óptica diferente, una óptica con la cual no hubiesen podido contar los personajes históricos reales que sirven de trasfondo a la narración. Así parece entenderlo Aínza cuando afirma como caracterización de la nueva novela histórica que "la re-lectura histórica propuesta por el discurso ficcional impugna la legitimación instaurada por las versiones oficiales de la historia” (1991;83). Así, con el cambio de foco que, por lo demás es siempre en este tipo de narraciones anacrónico, puede observarse como puede haber una alternativa a mirar la historia, claro está, desde la ficción más no desde la reconstrucción de un espíritu de época ${ }^{28}$.

\section{El objeto de la nueva novela histórica}

A continuación procuraremos ampliar dos detalles que pueden expandir nuestra mirada sobre la nueva novela histórica: el objeto de la nueva novela histórica y la vinculación con la verdad de hecho. Debemos comenzar por el primero de los apartes aquí enunciados. Casi al iniciar el texto de Menton nos encontramos con un propósito revelador en el quehacer de la nueva novela histórica. Ese quehacer literario que ha tomado el derrotero del relato histórico transfigurándolo sensiblemente hasta conducirlo al punto de la ficcionalidad persigue un propósito sumamente extraño al de la novela histórica, evadir la verdad histórica. Menton trata como acontecimiento clave para el surgimiento de este nuevo género literario "la aproximación del quinto centenario del descubrimiento de América" (1993; p. 48). Esta frase no deja de maravillar al ojo que simplemente se enfoca en la teoría literaria y la asume, en su pretendido purismo, alejada de todo acontecimiento social.

La celebración de los quinientos años del descubrimiento de América ha provocado una reacción sobre el género literario. Esa reacción no es, en esta ocasión, el resurgimiento de un orgulloso espíritu nacionalista, por el contrario, se encarna en la evasiva manera de celebrar un sentimiento que causa indignación. El saqueo, la violación de la intimidad indígena en cualquiera de las implicaciones en las que se le mira, el sometimiento de sus cosmovisiones no pudo más que detonar un sentimiento para una generación que comienza a tomar conciencia de sí misma, un profundo rechazo hacia lo que se consideró más que un proceso de civilización, un proceso de sometimiento a la voluntad de un pueblo excesivamente voluptuoso. Unos renglones más adelante esta idea que se anuncia un tanto tímidamente vuelve a señalarse en Menton:

Aunque todos los congresos y todas las celebraciones respecto al quinto centenario han contribuido sin lugar a dudas al auge de la novela histórica 
y al cuestionamiento del papel de América Latina en el mundo después de 500 años de contacto con la civilización occidental, una interpretación más pesimista es que la situación cada día más desesperada de América Latina entre 1970 y 1992 ha contribuido a la moda de un género esencialmente escapista (Ibíd; 51).

Como una evasión de la realidad, como ese sano ejercicio en el quela mente escapa a lo que tiene en frente para poder aislarse de la situación real pero sublimándola en otra cosa, en un relato que echa mano de la ficcionalidad, es así como se conforma, frente a los problemas de un agonizante siglo XX, la nueva novela histórica.

Pero pese a ser un género completamente "evasivo", en la nueva novela histórica debemos encontrar un algo a evadir. Ese algo que se consolida como aquello que nos hace frente es nuestra propia realidad, nuestra propia historicidad. La evasión aparece en tanto que con este tipo de relatos se escapa precisamente a aquello a lo que no queremos hacerle frente, a una época de colonización, a unas prácticas de explotación que, y esto es uno de los factores interesantes de dicha evasión, no queremos volver a revivir. De tal suerte pues, el hecho de hallarnos en frente de una nueva novela histórica nos sitúa en un nuevo tipo de conciencia histórica, esta vez una conciencia que no fortalece nuestro camino por lo que somos de una manera empecinada, sino una conciencia que ante la realidad, se evade.

Lejos de la evasión como mecanismo psicológico, comprendida ella como el ausentarse de la percepción del problema, verbigracia cuando cerramos los ojos ante algo espantoso, esta "evasión" que ejecuta la literatura tiene un nuevo tinte. Dicha "evasión" se ejecuta con un sutil viraje: recurre a aquello que en la narración breve se conoce como Cosmopolitismo. Salidos ya de un ámbito meramente regional, la nueva novela histórica nos coloca a dialogar con el ámbito de la cultura universal. Así parece hacerlo Germán Espinosa cuando al denunciar subrepticiamente los estragos de la Inquisición en la Cartagena colonial en su novela La tejedora de coronas, hace que una ciudadana cartagenera, Genoveva Alcocer, realice ciertas labores diplomáticas y científicas con personajes de la talla de Pascal o Montaigne, con el fin de promover esa nueva imagen de mundo que impulsó el Iluminismo.

En este punto puede verse con claridad como la "cultura regional" se inserta en un diálogo con la "cultura universal". El mero escape, la evasión, más que un símil del síndrome de la avestruz, muestra como las preocupaciones de una América sacudida por la voluptuosidad de Occidente, tienen un fuerte vínculo con el Antiguo Continente al no entenderse dicha problemática de lo que ha significado Europa en el devenir del hemisferio, como un hecho aislado. Así pues, el objeto que tienen este tipo de relatos no puede ser más que el de ejecutar una evasión a una versión de la historia que se ha erigido como canónica y que se procura, mediante el recurso a la 
ficcionalidad, contar de un modo diferente, más humano a diferencia de la manera en que nos fue transmitido dicho relato histórico.

\section{Vinculación con la verdad de hecho}

Ya hemos señalado algunos puntos centrales del objeto que persigue la nueva novela histórica. Allí hemos acotado que la nueva novela histórica no persigue, como bien pudiera entenderse en la novela histórica una vinculación con la verdad de forma "directa", aquella pierde la confianza en aspectos que comúnmente entendemos como veros, tales como la razón, la historia, la verdad de la ciencia, entre otras. Puntualmente Álvaro Pineda en un artículo publicado para la revista Gaceta indica las fuentes de tal concepción.

Algunas figuras sobresalientes de nuestro siglo, como Valery, Heidegger, Sartre, Levi-Straus, Foucault han puesto en duda la cientificidad de la historia. Ya nadie cree en la posibilidad de rescatar un pasado en su verdadera dimensión. Si la realidad del presente se nos escapa, con mayor razón se escapa la del pasado $(1995 ; 47-8)$.

Vemos pues que autores como Heidegger, Sartre y Levi-Strauss han puesto en tela de juicio la pretendida construcción objetiva no sólo de un pasado, sino también de un cúmulo de informaciones que constituyen la realidad. Los primeros dos, Heidegger y Sartre, herederos del método fenomenológico creado por Husserl, efectúan dicha puesta en duda a partir de la evidente construcción lingüística y temporal profundamente subjetiva del individuo en relación con su medio circundante en contra de una lectura teleológica (destinada a la consecución de un fin específico) tanto de la historia como del ser humano que empieza a ser denominado ya, en ambos pensadores pero con diferentes matices, como un ser-ahí. En el caso de LeviStrauss hay una reflexión en torno a las estructuras psicológicas que el individuo hereda del universo que lo circunda y que entran en juego al momento de dar un juicio sobre algún hecho del mundo; la religión y el mito son un claro ejemplo de cómo estos relatos atraviesan las concepciones de mundo de los seres humanos, relatos que, por lo demás, habían sido dejados de lado pretextando que ellos no daban una clara razón del mundo empírico. Es entonces en esta dirección que encontramos la existencia de un descreimiento sobre la verdad histórica entendida como verdad objetiva sin más. Así pues, es completamente necesario señalar como se elabora ese descreimiento de la verdad histórica en la nueva novela histórica.

En Menton encontramos una primera alusión a ese problema que se teje con la verdad de hecho en relación a las nuevas novelas históricas ya frisando la página 133. Allí se nos señala que 
En contraste con "Los Perros del Paraíso" de Abel Posse, que carnavaliza la historia con anacronismos descarados, retratos ficticios de personajes históricos y citas de textos apócrifos, Fernando del Paso nombra sus fuentes históricas y literarias para elaborar retratos detallados, multifacéticos, pero sin embargo no definitivos de sus personajes históricos (1993; 133).

Como puede verse la categoría bajtiniana de la carnavalización a la cual ya habíamos hecho referencia designa un componente esencial en la determinación del género: la alteración desmesurada de la historia, de la vida de los individuos históricos y la referencia a textos inexistentes pone en gran aprieto la vinculación de tal relato con la verdad de hecho. De dicha forma la historia se torna una especie de juego en donde se hace un divertimento con lo que tenemos de ella como posibilidad, es decir, abarcando el campo de lo posible en relación con lo que de hecho es así. De tal suerte podemos encontrar también un descreimiento en la autoridad de la escritura con el firme procedimiento de hallar "citas de textos apócrifos". Cabe recordar que la cita rigurosamente diligenciada es el elemento que configura la forma moderna de hacer pensamiento, de reconocer el peso de la tradición sobre nosotros en lo que estamos elaborando. De tal manera, abandonando el artificio clásico con el que se elabora la historia, y aún más rechazando el de la tradición al haber introducido la duda en el mecanismo de la cita, al tornarla apócrifa, nos hallamos ante la cimentación de una nueva forma de realidad, de una realidad inventada, ficcional en un muy alto grado, entregada por las palabras a la imaginación del lector, cimentando de tal suerte una realidad posible.

Dicha nueva realidad, más que ser un apunte subrepticio es, a cabalidad, un mundo verosímil. Con el apoyo de las referencias indirectas entre textos, que era lo que anteriormente denominábamos con la categoría bajtiniana de intertextualidad, se construye esta realidad completamente ajena a lo sensible, incluso a la datación histórica. Así nos lo refiere Menton cuando señala, a propósito de la literatura de García Márquez lo siguiente: "Mientras El general en su laberinto se distingue de las N.N.H ${ }^{29}$, incluso irónicamente de Cien años de soledad, por su falta de intertextualidad, si muestran bastante autointertextualidad, sobretodo con Cien años de soledad" (1993; 176).

La "autointertextualidad" que Menton menciona en su texto es simplemente la referencia cifrada, y no directa, es decir, sin emplear el mecanismo de la cita a otras reflexiones literarias del propio Márquez. Esto puede llevarse a cabo, como efectivamente lo hace Márquez, vinculando personajes de otras novelas suyas al

29. Hay que anotar que cuando Menton apunta las siglas N.N.H citadas aquí, el escritor entiende por ellas la Nueva novela histórica (esta nota aclaratoria es nuestra). 
relato que en ese momento se está narrando. De esta manera tanto en el intertexto, la referencia cifrada en otros textos escritos por otros autores, como en las referencias autointertextuales se teje esa forma de construir mundo que denominamos fundamentalmente realidad.

Esta, como puede verse, ya no es la realidad histórica que datan los periódicos o captan nuestros ojos: no es la realidad verídica; más bien podríamos señalarla como una para-realidad. Dicha forma de la realidad se torna un algo complejo de desentrañar pues, no todo puede considerarse como una ficción, ni es todo, en absoluto, correspondiente con la realidad histórica. Así parece sostenerlo Menton a propósito del texto Aventuras escritas por E. Ziller

Además de sus características bajtinianas, delo dialógico, lo carnavalesco, la intertextualidad, la parodia y la metaficción, Aventuras de Edmund Ziller concede más importancia a los conceptos filosóficos borgeanos de la historia que a la reacción realista de los distintos periodos históricos. A pesar de no tener protagonista histórico, sí tiene algunos personajes históricos que desempeñan papeles secundarios con las consabidas distorsiones juguetonas $(1993 ; 223)$.

Más allá de Bajtín, en esta referencia de Menton aparece otro grande de la literatura: Borges. Este hombre que responde según lo afirma Umberto Eco a la suma indolente de ciego más biblioteca, pone en juego una categoría del tiempo que es bien compleja. Ese tiempo, que más que ser una aristotélica sucesión de instantes es, con mucho, un completo Jardín de senderos que se bifurcan: el tiempo no meramente como un inmisericorde acaecer de instantes sino comprendido como opción multifacética de existencia se presenta como un tiempo no lineal, sino anclado a las posibilidades del hombre en un tiempo total, un tiempo del cual la literatura, en su invención, puede servirse. ¿Qué podemos entender de todo esto? Lo que definitivamente llama la atención del apunte realizado por Menton es, más allá de la referencia al ámbito de lo no histórico, la designación de una pequeña distorsión que hace del acontecimiento, algo fundamentalmente otro.

Así pues, más que una novela que reconstruye los grandes acontecimientos del ser humano en la historia, la nueva novela histórica es un relato de la posibilidad. La posibilidad ha de estar entendida no en la variabilidad de una gran situación histórica, sino precisamente en lo eventual, en lo instantáneo, en la valoración precisa del momento histórico en que la decisión es tomada posible y ficcionalmente en otro sentido, no necesariamente contrario, al que nos ha narrado la historia como saber "científico" y, simplemente, puesta en otro extremo diferente.

Como puede verse, en el apunte antes cifrado, la para-realidad se teje sobre 
un ambiente verosímil. La inmersión de personajes históricos pero, al tiempo, de diversas situaciones históricas con un alto grado de ficcionalidad nos impulsa a pensar en una historia más que verosímil, posible: así parece indicárnoslo una vez más Menton en ese comentario a propósito de Respiración artificial de Ricardo Piglia: "Tal vez la mejor justificación para encasillar Respiración artificial como N.N.H es la ausencia casi total de la recreación del espacio histórico" (1993; 194). De esta manera podríamos señalar que el objetivo fundamental de una nueva novela histórica en relación al saber de la historia no es, en mucho, el tomarla tal y como ella es con el fin de dar una versión mucho más sensible de lo ocurrido, sino, contrario a ello, tomar a la historia como un mero dato, como un telón de fondo, susceptible en su formulación de una ligera pero fundamental alteración.

De esta manera podemos comprender aún más el cortejo de la nueva novela histórica con la característica de su vinculación con la verdad de hecho. Menton nos indica acerca de ello que esta, la nueva novela histórica, constituye un asunto importante. Menton dice:

Que un argentino haya escrito una novela acerca de Cristóbal Colón, quien se asocia más con la historia del caribe, durante un periodo en el que sus compatriotas estaban investigando con actitud revisionista la historia nacional dentro de su contexto de la dictadura militar de 1976-1983 puede parecer un acto escapista y antipatriótico pero está totalmente armonizado con el carácter dialógico, carnavalesco -en fin bajtiniano- del texto. (1993; $102-103)$.

Tal y como puede verse, la anterior referencia hace hincapié en dos problemas de las cuales nos hemos de centrar en uno que ya habíamos abordado: el de asumir la nueva novela histórica como un género esencialmente "evasivo". En esta situación la nueva novela histórica se muestra como tal en tanto que, contrario a guardar un compromiso político e histórico, el escritor en mención, a quien se dedica la anterior cita, Pessoa, evade la problemática de su tiempo y retoma una completamente diferente. Así pues, por lo que respecta a este género, la literatura ha de tornarse una expresión estética fundamentalmente libre, escapista, no comprometida más que consigo misma; no atada a un tiempo determinado ni a una ideología preestablecida ${ }^{30}$.

\footnotetext{
30. En Solanilla se leen las siguientes categorías en la "escritura postmoderna" o lo que compagina en nuestra indagación como el "concepto" de nueva novela histórica:

1. La novela postmoderna juega a romper los límites entre realidad y ficción (...).

2. La escritura postmoderna descree de la autoridad (...).

4. La obra postmoderna admite no sólo la intertextualidad (...) (Op cit; 40-41).
} 


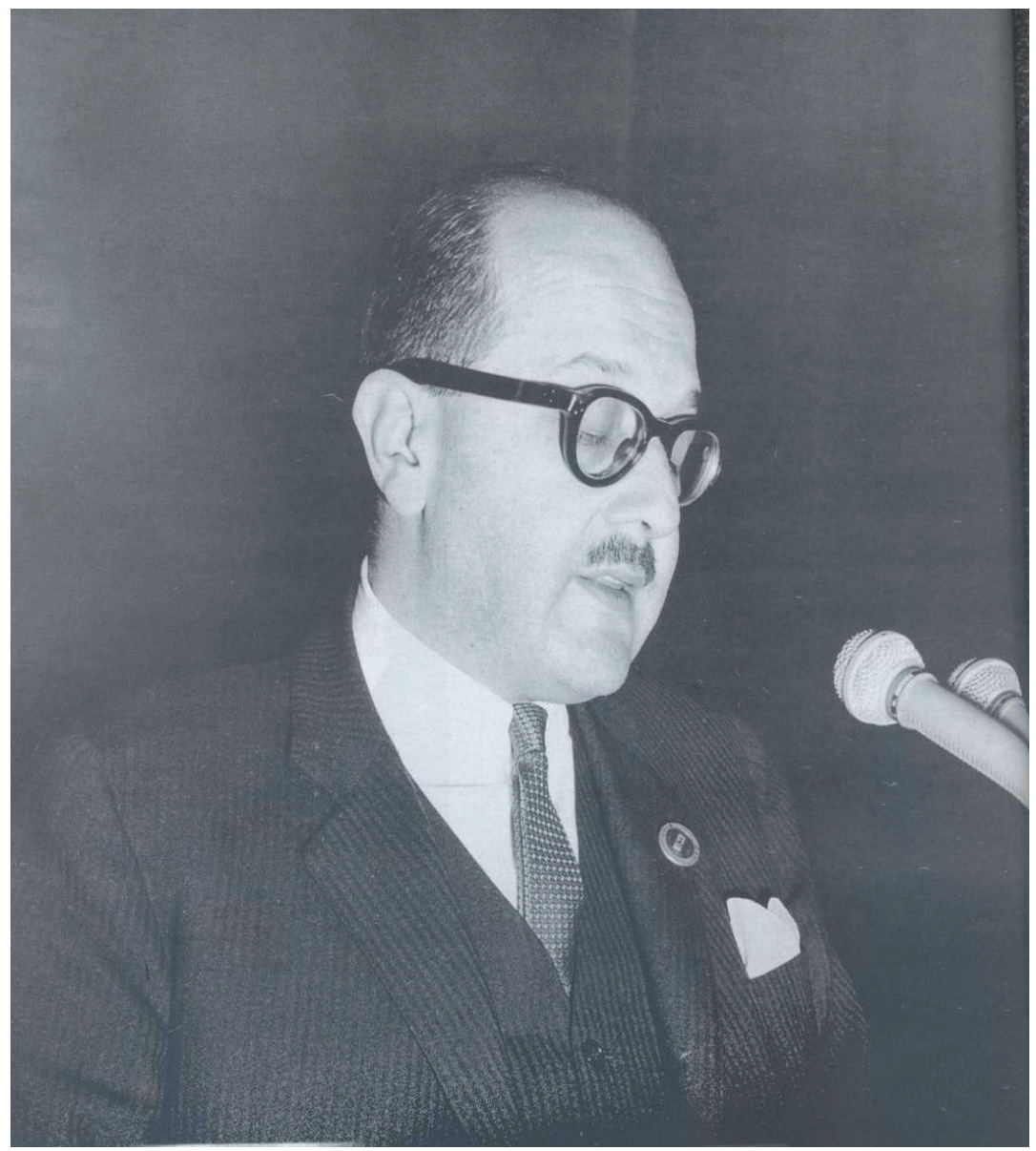

Imagen publicada en el artículo de Taborda Sánchez Juan F. (2006, Abril-Junio). Historia y brujería en los cuentos de Pedro Gómez Valderrama. Revista Universidad de Antioquia,

Número 284. p. 69 


\section{CAPÍTULO TRES}




\section{Consideraciones en torno a algunos apartes de la obra de Pedro Gómez Valderrama ${ }^{31}$ y La otra raya del tigre}

Y ahora, justo después de haber recorrido el camino que de Luckacs conduce a Menton en la teoría y de Walter Scott a Germán Espinosa en la práctica, para efectos de lo que concierne al aspecto formal que circundan los géneros literarios, es necesario devolvernos un momento en el tiempo y preguntar no sólo por las ideas formales que rodean la novela de Gómez Valderrama sino por aquello que "sea" nuestro objeto de estudio: La otra raya del tigre. Nuestra pregunta estará encaminada, como ya lo hemos sostenido con antelación, a descifrar si aquello que forja Gómez Valderrama en su novela La otra raya del tigre es meramente una novela histórica o en su defecto, según lo hemos observado, una nueva novela histórica y por qué lo hace de uno u otro modo. Para ello será necesario, previamente, declarar nuestro punto de vista sobre el escritor en mención y elaborar algunas consideraciones sobre su obra. Con ello esperamos aproximarnos a una visión más completa de lo que "sean" tanto la obra como quien la forja

El escritor santandereano que se hizo popular en el ámbito literario a raíz de la publicación de sus cuentos que, entre los muchos temas atinentes a la tradición occidental, reflejan una historia de latinoamérica es, a nuestro parecer, uno de esos "satélites" que "planetas" como García Márquez en Cien años de soledad, nos obligan

\footnotetext{
31. Para la elaboración de este apartado y, en general, de lo que de este documento sigue, hemos consultado, además de las obras del autor, que se señalarán en las páginas que vienen, algunas reflexiones sobre el autor. Aquí relacionamos, en primer lugar algunos estudios específicos sobre el escritor y luego, algunos artículos publicados sobre él. Entre los libros dedicados tanto a su obra como a su vida encontramos los siguientes: Aristizabal, Alonso (1992). Pedro Gómez Valderrama; Correa Díaz, Luis (2003). Una historia apócrifa de América. El arte de la conjetura en Pedro Gómez Valderrama. Gonzáles Martínez S. (1994) La imaginación liberal: hipótesis para una lectura de "La otra raya del tigre"'; Por lo que respecta a los artículos de revista y apartados de libros en los que se encuentra mencionado hallamos algunas referencias en Menton Seymour (1978) Novela Colombiana, planetas y satélites. Restrepo Henao Darío (1999, Julio-Diciembre) Gómez Valderrama o la utopía liberal; Suescún, Nicolás (1996, Noviembre) Las alas de Pedro Gómez Valderrama; Gómez Vila, Pedro Alejo (1994, Mayo) El tamaño de su corazón; Taborda Sánchez Juan Fernando (2006, Abril-Junio) Historia y brujería en los cuentos de Pedro Gómez Valderrama; Giraldo Alexander (Ibíd) De las versiones apócrifas de la historia a la historia como invención; Campuzano Montoya Pablo (Ibíd) Variaciones en torno a Pedro Gómez Valderrama; Aristizabal, Alonso (Ibíd) Contrahistoria viva de Pedro Gómez Valderrama; -------(Ibíd) Gómez Valderrama viajero de la vida y el universo de la imaginación; García Londoño Andrés (Ibíd) Sensualidad y Libertad en Pedro Gómez Valderrama; Restrepo David Juan F. (Ibíd) Los Viajes de Pedro Gómez Valderrama; Correa Díaz Luis (1994; Enero-Abril), El grito colombiano de “Tierra!” en el relato de Pedro Gómez Valderrama; Abad Torres, Alfredo (2007), La ficción histórica en la cuentística de Pedro Gómez Valderrama. En Filosofía y literatura, encrucijadas actuales; Valencia Solanilla, César (2008), De la periferia al centro: la novela finisecular del Eje Cafetero.
} 
a estudiar con el fin de comprender ese fenómeno de la literatura colombiana (cfr. Menton; 1978;9). Tal denominación, emanada desdela letrada concepción de Menton en ese momento de su reflexión crítico-literaria, La novela colombiana, planetas y satélites, lejos de ser un estigma degradante de la obra de Gómez Valderrama, hace una referencia explícita a la totalidad que refiere el ejercicio literario del ex ministro de educación que nos incita a su lectura ${ }^{32}$.

Con ello ya hemos anunciado aquí un par de asuntos: la justificación en la elección de este escritor y, sumado a ello, el haber escogido una obra literaria agregada a un compromiso político aunados en una sola existencia. Entraremos ahora a hablar de aquellos aspectos que conforman la obra literaria de Pedro Gómez y luego consideraremos su postura política que, por lo demás, cabe adelantar, no es extraña a su ejercicio como escritor. Su obra literaria, dentro de la cual está inserta nuestro objeto de estudio es sumamente rica a nivel de géneros. Ensayo, poesía, cuento y, finalmente la novela son un gran indicio de su cortejo a la escritura. En cada uno de estos géneros Pedro Gómez hace hablar a una tradición que es profundamente propia con aspectos formales y de contenido que se enriquecen de la herencia dejada por Alejandro Dumas, Walter Scott, Dostoievsky y otros baluartes de la cultura occidental ${ }^{33}$. A continuación ofrecemos una descripción de los títulos que hemos consultado con el fin de mostrar cómo ha sido, por decirlo de alguna manera, enriquecida la periferia del corpus de nuestro trabajo que, como ya lo hemos sostenido es la novela La otra raya del tigre; mas, no siendo con rigor nuestro objeto de estudio, examinados estos textos periféricos con detenimiento contribuirán a ofrecer una imagen "completa" de la reflexión literaria de Gómez Valderrama. En su orden cronológico de publicación, según tenemos a mano las ediciones de los textos, son:

- Nosotros y la libertad (1958). Bogotá. Fundación Universidad de América.

- El retablo de Maese Pedro (1967). Bogotá. Ed. Cosmos.

- Muestras del diablo (1970). Bogotá, Círculo de Lectores.

\footnotetext{
32. Esta consideración de Menton, que anima al estudio de la obra de Gómez Valderrama, pronto queda opacada. Al llegar a la página 326 se lee en Menton: "Mientras varios escritores no han podido resistir a la atracción del maestro de Aracataca en la invención de personajes rabelesianos" (...) y acto seguido anota al pie de la página dos obras y dos escritores, a nuestros ojos, valiosísimos por sí mismos "Los cortejos del diablo (1970) de Germán Espinosa y La otra raya del tigre (1977) de Pedro Gómez Valderrama”. Así pues, pese a estas palabras iniciales, Menton, condicionado por esa obra arrolladora, seductora, mágica, de Márquez, hace caer al lector de su texto en un caro error de apreciación hermenéutica: condicionar la mirada de una obra a la luz de otra "mucho más grande".

33. Entre ellos podemos citar aquí algunos que incluso se referencian en su obras tales como: el Marqués de Sade, Miguel de Cervantes, El Bosco, Niccolo Paganini, Kant, Platón. Stendhal, Cristóbal Colón, los generales Santander y Bolívar, Marco Polo, Schopenhauer, César Becaria, Goethe, Mozart, Beethoven.
} 
- Los ojos del burgués (1971). Bogotá, Editorial Argra.

- La procesión de los ardientes (1973). Bogotá (sin nota sobre la editorial).

- Invenciones y artificios (1975). Bogotá. Ed. Colcultura.

- La otra raya del tigre (1977). Colombia, Siglo Veintiuno Editores

-La nave de los locos (1984). Madrid, Ed. Alianza.

- Antología (1995). Bogotá, Instituto Caro y Cuervo ${ }^{34}$.

Nótese cómo hemos señalado la existencia de estas obras en relación a la fecha de su publicación y no en orden alfabético. Ello, el hacer tal taxonomía, nos permite tocar de manera indirecta la vida del escritor. En las líneas que vienen nos centraremos en hacer una breve mención de esos textos que conforman la periferia de nuestro corpus, La otra raya del tigre y que al tiempo contribuyen a esclarecer una postura política de Pedro Gómez Valderrama: su pensamiento liberal. Tales textos en donde se exhibe su cuentística son El retablo de maese Pedro, La procesión de los ardientes, Invenciones y artificios, La nave de los locos y una parte de la Antología. Comenzaremos pues, por señalar cómo Pedro Gómez elabora, a nuestro juicio, en la novela La otra raya del tigre un relato que posee como máscara, como género literario, el andamiaje de la novela histórica, contrario a lo que se lleva a cabo en su cuentística, donde se aborda el género de la nueva novela histórica o lo que ha venido a llamarse recientemente, escritura postmoderna.

\section{Apuntes preliminares sobre "La otra raya del tigre"}

La obra ya mencionada ha recibido sobre su lomo el peso de disímiles críticas que en la mayoría de las ocasiones provocan juicios apresurados o predisposiciones al momento de hacer un lectura de dicha novela. Se le ha calificado como heralda del pensamiento burgués, fomentadora de la perniciosa industria, emisaria de la corrupción moral europea, defensora de todo tipo de aberraciones sexuales, una novela puramente ficcional (cfr. http://giron.gov.co/documents/books/book131-136. pdf Octubre 25 de 2008); o recientemente como una obra que acude generalmente al mito como elemento estructural (cfr. Solanilla, 2008; 33-34) y como una novela con trasfondo histórico (Ibíd; 220). No obstante, pese a la pluralidad de calificativos que, como veíamos en las primeras anotaciones, no pasan de obedecer a un escaso juicio moral, fomentado, tal vez, por un comportamiento ético labrado en las arduas 
y ascéticas lecturas del Catecismo mariano, la obra de Gómez Valderrama que ha de ser nuestro objeto de estudio en lo que resta de esta indagación es un punto central en la literatura de Colombia; más que un "satélite" ella misma es un "planeta" que abre las puertas a quienes se dejan introducir, como Lengerke, por el Río Grande del Magdalena.

Aquí, en esta narración, en La otra raya del tigre, ya no hay un decidido juego con el universo de la historia posible y en tal medida lo ficcional adquiere un matiz diferente. En ella se muestra un suceso o el encadenamiento de una serie de sucesos que contribuyeron a formarle unas prominentes rayas (caminos) a los suelos de ese gran tigre denominado Santander. La industria, la nociones de empresa y progreso, tan caras a nuestra mentalidad moderna, afloran en el relato de Gómez Valderrama construyendo una escenografía de colonización industrial que más que apelar al mito recurren a la confrontable leyenda. Empero, pese a ser este el escenario en donde se desenvuelve la escritura de Gómez Valderrama, no por ello podemos llegar a aseverar como aparece en una nota de la Casa de Poesía Silva, puesta en Internet (www.arquitrave.com/periodico/periodico_casa_silva.html; Septiembre 26/2008) lo siguiente:

El papá del Doctor Pedro Alejo es autor también de una novela reaccionara, La otra raya del tigre, sobre las aventuras y crímenes de un Alemán, uno de los más alevosos terratenientes que haya conocido Colombia, Geo von Lengerke, propietario de más de once mil hectáreas en el departamento de Santander. El papá del Doctor Pedro Alejo, considera que el fracaso de Lengerke al no poder llevar a buen término sus empresas de explotación de los naturales y los mestizos en sus plantaciones de quina, es "nuestro fracaso".

Este comentario, que sólo puede venir de alguien ajeno a toda consideración de un juicio estético correctamente fundamentado, extraño al saber teórico de la literatura, tiene varias dificultades para presentar de tal manera la obra del ex canciller de la Unión Soviética. En primer lugar considera a la novela una novela de personaje, la cual exclusivamente centra su mirada en aquello que ha de realizar Lengerke. Sí, no hay que dejarlo de lado, incluso en este trabajo retomaremos este tópico al estudiar la visión de mundo del alemán. No obstante en ningún momento, y con esto coinciden quienes por más años han frecuentado la literatura, Lengerke no es retratado como un hombre libre de toda mancha ni mucho menos se constituye como un héroe a ensalzar al ser el personaje fundamental de la obra. Además, la apreciación citada en extenso también peca de una gran falta de juicio estético al considerar la obra novelada de Pedro Gómez Valderrama una novela de tesis o, en 
su defecto, testimonial; baste recordar que en el primero de los géneros se privilegia la demostración de un postulado que por lo demás se lleva a cabo sin reparar en el uso adecuado de recursos estéticos, como acontece en El día del odio (Cfr. Osorio Lizarazo, 1998). En lo que se refiere al segundo, a la novela testimonial, ella es la narración de un hecho dentro de la época en que él mismo sucede relatado en la voz del autor, como bien lo ejemplifica la novela Viento seco (cfr. Caicedo, 1954). Lo que en realidad habría que demostrarle al hombre que hace tal juicio, es que lo tenido en cuenta como trasfondo es, en consideración misma de la etimología de la palabra, el subsuelo de la historia, más no lo relevante de ella como fenómeno estético.

Más bien debe considerarse La otra raya del tigre como el relato de una instancia cronológica en la cual se muestra el surgimiento de un nuevo pensamiento y por lo tanto como novela histórica y no como una novela con trasfondo histórico, lo que aquí se ha estudiado como nueva novela histórica. Esta hipótesis de lectura es la que deja ver Serafín Gonzáles en su texto La imaginación liberal: hipótesis para una lectura de "La otra raya del tigre" (1994). Empero, pese a lo valioso del documento el texto prontamente recorre algunos apartes de la obra de Gómez Valderrama y olvida la elaboración detallada de su punto central, el análisis de La otra raya del tigre, dejando de lado el comentario de textos de opinión elaborados por el propio escritor de la novela, como lo son sus variados ensayos en donde el tema de la ideología liberal se encuentra más que presente. Este aparente "descuido" en la forma de abordar el problema se justifica en la premura por abordar la seductora obra cuentística de Gómez Valderrama. Tal vez todo este "despiste metodológico" tenga lugar a causa de que Gonzáles no propone una metodología de trabajo que clarifique decididamente el andar de su pensamiento a través de los doce capítulos que compone su reflexión; el autor simplemente expone el propósito de su texto que, por lo demás fue de una invaluable ayuda en la construcción de estas líneas dedicas al hombre que compartió la sagrada consigna de la revista Mito: las palabras están en situación.

Uno de los tópicos más recurrentes en el pensamiento liberal, que atinadamente rescata Gonzáles de la obra de Gómez Valderrama es la vindicación de lo erótico. Es bien cierto que rescatar las manifestaciones corporales del amor constituye una fuerte base del pensamiento liberal, anclada en la consigna que propugna el respeto a la libertad de expresión y a las individualidades del otro, empero, esta mentalidad liberal manifestada en lo erótico va más allá, posee otros matices que hacen de la propuesta de Gómez Valderrama algo exuberante. Atinadamente Gonzáles señala:

(...) es un esfuerzo en que la modernidad apenas se construye como un tejido ralo, muy laxo, por cuyos resquicios asoman pertinazmente la voz pastoril, los rituales premodernos de clientelas y abrazos compadreros; 
esa tenacidad obstinada de la parroquia y de la cultura del catecismo por sobrevivir en el óxido de sus propias ritualidades (1994; 81).

Así la obra de Gómez Valderrama retrata fielmente ese paso de aquello que puede concebirse como premoderno a algo moderno; si se quiere tómese ello como el paso de un mundo divinizado, absolutista, a otro en donde la desacralización se roba la escena, a un mundo en donde los dioses nos han dejado solos y, en su lugar han dejado el fantasma de la técnica y el progreso (Cfr. Gómez Valderrama, 2003; 49 y ss; 96$)^{35}$.

Ahora, lejos de estas consideraciones generales que circundan la obra de Gómez Valderrama, nos parece pertinente hablar un poco de la estructura misma del texto a abordar: La otra raya del tigre. No se encuentra mal ubicado Gonzáles cuando coloca la génesis de la novela de Gómez Valderrama en un cuento publicado en 1973: El dios errante. Allí, se narra el viaje de un piano que sale de Liverpool y llega hasta las tierras santandereanas; ese relato se encuentra cifrado con algunas modificaciones dentro del texto que constituye nuestro corpus.

Cabe anotar que dicho cuento, El dios errante fue alcanzado a escuchar por el padre de Valderrama. Como bien se sabe la novela de Pedro Gómez es un proyecto generacional; el abuelo de Valderrama, contribuyó sensiblemente a la formación de la novela, como también lo hizo su padre, tal y como lo deja plasmado Valderrama en su texto ${ }^{36}$. Así lo señala el propio escritor en una entrevista hecha para el programa Palabra mayor que realizaba, en ese entonces, la productora Audiovisuales ${ }^{37}$. Ahora bien, lejos de las referencias extratextuales este texto, en su composición formal evidencia tal detalle. La novela se encuentra fragmentada en ocho grandes capítulos que a su vez posee unas fragmentaciones cortas, subcapítulos que no pasan de ser más de quince dependiendo del capítulo. Así, la mayor parte de la novela se encuentra focalizada por el abuelo pero narrada desde Pedro Gómez. Hay un subcapítulo que llama la atención en tanto que se encuentra narrado y focalizado desde la óptica del padre de Gómez Valderrama (cfr. 2003; 63-68). Así pues como puede observarse la empresa de ejecutar una novela histórica desde esta forma de escritura es del todo un acontecimiento literario.

35. Sí, es bien cierto, la idea de progreso no sólo se hace evidente en esta parte del texto, ella también se encuentra depositada a lo largo del trabajo de Gómez Valderrama. No obstante es desde este capítulo en adelante desde donde la idea de progreso se desarrolla en toda la obra novelada, una idea de progreso que se apareja al mundo del comercio.

36. Esta empresa de situar la novela como un proyecto generacional es bien elogiable, por no decir única. Aparte del testimonio dado aquí por Gómez Valderrama encontramos el comentario de Alonso Aristizabal que señal también esta particularidad (Cfr. Aristizabal, 2006; p 86-7).

37. Este documento fílmico, dividido en dos partes, ha sido transmitido por el Canal A en junio 2 del año 1992. En la biblioteca Luís Ángel Arango descansa un ejemplar de dicha grabación. 
Así pues, lo que el lector tiene ante los ojos cuando se sirve abrir el texto que lleva por nombre La otra raya del tigre es un trabajo conjunto. Lejos de pertenecer claramente a la inventiva particular de un hombre, la novela de Pedro Gómez recoge el legado de tres generaciones, una herencia literaria que hubiera preferido, según lo expresa el propio autor, la contara su padre. Baste tan solo recordar ese aparte del capítulo en donde Valderrama hace narrar a su padre una visión de la historia, una descripción de Lengerke, desde su cargo como auxiliar de juzgado para decir

(..) el cura decía que es hereje, sin embargo el hombre le dio monedas de oro para la iglesia y cuando pasa por el atrio se descubre, y ayer me dijeron que lo vieron descubrirse también ante la puerta de la Capilla de Santa Bárbara, junto a la casa que yo quiero comprar algún día cuando tenga dinero y regrese de estudiar en Bogotá, si mi padre me puede mandar, aunque sea a pie $(2003 ; 66)$.

Como se puede apreciar en este aparte y en lo que resta del subcapítulo en donde esta cita se halla inmersa, hay un cambio de foco en la narración; se hace notoria una voz más juvenil que en las narraciones anteriores; es una narración voluptuosa, que desea, que envidia la masculinidad de Lengerke; una voz que se construye con una sensación de ligereza en el habla al estar construida formalmente, en su mayoría, por ligeras comas a diferencia de como se nos muestra la voz del abuelo Juan de Dios: una voz que se caracteriza por observar, por contemplar y que se encuentra construida fundamentalmente separando sus oraciones por medio de puntos.

No estamos alejados de la realidad si consideramos aquella obra, como ya se había indicado, dentro de los parámetros que hemos señalado en el capítulo I para la comprensión de la novela histórica, como una novela perteneciente a este género y no como una nueva novela histórica. Es pertinente recordar que La otra raya del tigre posee una intención ideológico-política, la difusión de las ideas de un pensamiento liberal propio del escritor; se preocupa fundamentalmente por ejecutar una arqueología de la historia de Santander; contiene casi reiterativamente la idea de progreso $\mathrm{y}$, como si fuese poco, los hechos que narra pueden ser fácilmente contrastados con una realidad que, si bien no es del todo fiel a la narración del texto (y es aquí donde aparece el carácter ficcional de la obra), si lleva, como habíamos señalado, su alta dosis de veracidad historiográfica; además de ello hay que anotar que en dicha novela aparecen con gran relevancia elementos tales como el castillo (cfr. Ibíd; 71 y 92) y los caminos. Sí, es cierto, con ello no hemos dado un gran paso y contrario a esto nos hemos dejado llevar por lo que el mismo escritor atestigua precisamente en una de sus entrevistas y lo mismo que han sostenido sus disímiles críticos. 
No obstante es necesario señalar más argumentos que aclaren no solo por qué dicha novela pertenece a un género y no a otro sino, igualmente, con qué fin. En primer lugar hemos de señalar que su personaje central Geo von Lengerke, es un personaje efectivamente real anclado a una época determinada, el siglo XIX entre Europa y Colombia. Pero, más aún, en la medida en que, con facilidad, podemos contrastar diferentes hechos que acaecen en la obra y que la narración registra como lo son el poder tener información sobre la repercusión social de su empresa en la explotación de la quina y, junto a ello, el hecho de haberle abierto unas primeras vías a Zapatoca en donde aún hoy se puede encontrar su tumba (cfr. http://fis.unab.edu. co/docentes/olengerke/geovonlengerke/ Septiembre 26 del 2008).

Algunas de las objeciones que bien se pueden hacer en cuanto a la consideración de La otra raya del tigre como una novela histórica y no como una nueva novela histórica o, como ahora se le denomina: novela con trasfondo histórico, obedecen a la forma en que es narrada. Es cierto, en el texto aparecen categorías bajtinianas que habíamos señalado eran potestativas de las nuevas novelas históricas. En primer lugar un plurilingüismo, es decir que el texto no se encuentra referido en una sola lengua y que reconstruye, en muy breves apartes de la forma de hablar de ciertas mentalidades sociopolíticas de la época e incluso gramaticalmente hay una redacción, una carta, que hace evidente el uso de tal categoría (cfr. 2003; 334). Añadido a lo anterior puede señalarse que en la narración hay un detalle de la construcción de la obra (cfr. Ibíd; 388); y, por si fuera poco, la inmersión de un cuento El dios errante en su obra (cfr. Ibíd; 107-114). Sí, todas estas objeciones son válidas, empero hay que mirar el uso que se hace de dichas categorías en relación al objetivo que se propone la creación literaria de Valderrama. En cuanto al plurilingüismo que aparece en la obra este detalle favorece excesivamente la recreación histórica ideológica del siglo XIX. Por lo que toca a los detalles sobre la construcción de la obra hay que anotar que ellos se muestran una vez que la focalización y narración tanto por parte del padre como del abuelo han llegado a su punto final, lo que posibilita entrar a Pedro Gómez en escena y, así, de esta forma explícita, hacer de la novela un proyecto generacional; la inmersión del cuento antes señalado no puede indicarse como un diálogo intertextual, sino como el acoplamiento de una reflexión literaria breve a esta que es de suyo mucho más extensa. Así ambos detalles, aunque pertenecientes al universo bajtiniano del análisis literario contribuyen a elaborar una visión reconstructiva de ese espíritu epocal del siglo XIX que ha sido también, como ya se ha señalado, una empresa familiar.

Por ello, por el complejo número de evidencias recolectadas hasta este punto y añadido a ello por la forma de narrar lo ocurrido en la novela, debemos señalar la pertenencia de la novela a este género. No así con el de la nueva novela histórica. 
Sí, es bien cierto, nuestro escritor coquetea con ambos géneros; no obstante, y como veremos seguidamente, en los libros de cuentos, El retablo de maese Pedro, La procesión de los ardientes, Invenciones y artificios y La nave de los locos es donde más puede verse el uso de este género de escritura literaria que, en la narración breve equivale a lo que puede denominarse bien como lo que se encuentra en Menton con el nombre de Cosmopolitismo o, de otro lado el Boom ${ }^{38}$ a despecho del género histórico, de la novela histórica. En particular porque este último hace una mayor diferencia a un sentido más "regional" que cosmopolita y porque intenta, como ya lo hemos señalado con anterioridad, hacer una reconstrucción de un espíritu epocal. En los cuentos hay un juego histórico con iconos de la historia universal, llámesele Andrés Bello, Cervantes, Stendhal u otros. Empero, dicho juego es contrastable con la verdad que sostiene la historia y fácilmente desvirtuable. Ello no impide que los sucesos que allí se narran puedan ser pensados mediante el artificio de la escritura y que sean de un alto valor literario. No así lo que sucede en La otra raya del tigre. Con toda esta reflexión previa se muestra la manera en que no gratuitamente Gómez Valderrama ha escogido un género, una forma de narrar, con un propósito que obedece también, estratégicamente, a una consigna del pensamiento liberal: el fortalecimiento crítico de una conciencia histórica ${ }^{39}$.

38. Hay dos citas que nos dejan sin saber a ciencia cierta a cuáles de las dos clasificaciones pertenece Gómez Valderrama. A nuestro juicio Gómez Valderrama coquetea mucho más en la narración breve con el cosmopolitismo que con el Boom. Se lee en Menton: “(...) El autor cosmopolita se preocupa mucho más por la estética, la psicología y la filosofía, aun cuando trata temas criollos como en el caso de "La lluvia" de Arturo Uslar Pietri. Frente a la temática criollista, los cosmopolitas se interesan más en el individuo, en la vida urbana y en la fantasía. Los escritores viven en grandes centros metropolitanos, conocen muchas partes del mundo y están al tanto de todos los movimientos literarios" (1970; 7).

Hasta este lugar el asunto parece claro pero, casi al finalizar el texto que lleva por nombre El cuento hispanoamericano, de donde hemos extraído la anterior cita, encontramos la siguiente referencia: "Otros autores siguen la interpretación borgiana de la historia ("Historia del guerrero y la cautiva"), inspirándose más directamente en los cuentos de Juan José Arreola (“Teoría de Dulcinea”) y de alejo Carpentier ("Semejante a la noche") para tratar acontecimientos o personajes históricos como si fueran actuales: El guatemalteco Augusto Monterroso (1921), los colombianos Pedro Gómez Valderrama (1923) y Álvaro Mutis (1923)” (Ibíd; 218).

La pregunta es clara ¿en cuál de las dos categorías ubicarlo sin desacreditar la postura de Menton? Me uno a la opinión de Darío Henao Restrepo (Cfr. Gómez Valderrama o la utopía liberal -1999; Julio-Diciembre- p. 92). Por lo pronto cumplamos sólo con exponer ambas teorías y, en comunión con la opinión del propio Gómez Valderrama pensemos que esta problemática obedece a un fenómeno característico de nuestra época como él mismo llega a afirmarlo: la difuminación de los géneros.

39. Para observar la relación entre pensamiento liberal y conciencia histórica en La otra raya del tigre véase Martínez Gonzáles (1994; 88). Hay que resaltar que la tesis de Martínez, aunque es bien pertinente cifra casi exclusivamente la relación entre liberalismo y conciencia histórica en los contenidos de la novela haciendo una antibajtiniana distinción entre lo uno y lo otro; lo que aquí se sugiere es que también la forma misma de la novela, el género que Gómez Valderrama escoge, está signado por el mismo espíritu liberal y, por lo tanto, por la misma preocupación en relación a la elaboración de una conciencia histórica (esta misma preocupación puede verse, en los rasgos generales que caracterizan a esta literatura. Cfr. Solanilla, 2008; 35-36). 


\section{El cortejo a la nueva novela histórica}

$\mathrm{Y}$, hablando de este género, es conveniente que no dejemos su nombre como una mera mención y será entonces necesario mostrar cómo opera en la narración breve de Gómez Valderrama. Para comenzar, señalaremos que es a partir de El retablo de maese Pedro, que se configura este género de escritura. Sus nueve cuentos: Tierra...!, Homenaje a Stendhal, Noticia de los cuatro mensajeros, La aventura de la nieve, La mujer recobrada, El corazón del gato Ebenezer, El maestro de la soledad, El hombre y su demonio e Historia de un deseo, se encuentran habitados por el espíritu de un historiador juguetón que en las soledades de su estudio se deleita con el reino de las posibilidades. Como puede observarse desde el rótulo de sus narraciones, en este lugar de su obra Pedro Gómez procura hacer un ejercicio con algunos de los contenidos fundamentales de la cultura. Es así que aparecen referencias a Stendhal, Carlomagno, Robinson Crusoe e incluso, el Bosco. La inmersión de estos personajes históricos que a su vez son un hito fundamental de la cultura busca, como ya lo indicábamos, simplemente un acercamiento ficcional a la historia mediante la vinculación de diversas situaciones hipotéticas fraguadas por Valderrama. Ahora bien, no sólo se encuentra en las narraciones breves una referencia explícita a personajes de nuestra historia como cultura. Los temas abordados, la magia, la preocupación fundamental por la libertad, el amor, son cada uno temas que conectan con la cultura occidental de una manera directa.

A continuación haremos una corta referencia a la narración breve quizás más comentada de Valderrama. En Tierra...! (1967; 7-13), uno de los relatos más citados acerca de la obra de Valderrama, encontramos la reconstrucción de una escena histórica de nuestro descubrimiento, del descubrimiento de América a través de los ojos de Juan Rodríguez Bermejo. Ello posibilita que, más que una desacralización de la historia como bien lo afirma el profesor Abad $(2007 ; 120)$, lo que acontece en este pequeño cuento, como lo hará en los demás, es la incorporación, mediante el artificio literario sumado al saber historiográfico, del lector moderno a una situación ya lejana: un hombre en un barco, en La Pinta, la noche en que se avista el suelo americano, en medio de una fantasía sexual que desemboca en el acto masturbatorio. El estudioso de la cuentística de contenidos latinoamericanos de Pedro Gómez, Luís Correa Díaz, cree ver en este acto un éxtasis copulativo del encuentro entre ambos mundos pero, no obstante, hay que recordar que dicho acto, el acto copulativo es completamente fallido en tanto que aquello que acontece es un simple espejismo, un abandonado fantasma que atraviesa la mente de Rodríguez Bermejo, un espectro que atraviesa el océano y se ancla en esta nueva tierra americana. De esta suerte, como un simulacro carente de realidad es que puede comprenderse mejor la metáfora copulativa que muy bien apunta Díaz, en tanto que la narración del acto masturbatorio, que es en 
donde parecen poner especial énfasis tanto el profesor Abad como Díaz, sólo ocupa un ápice de lo que es valioso en el texto al encontrarse relatado con milimétrica descripción: la narración de la cosmovisión de Rodríguez Bermejo al embarcarse hacia ese viaje temerario en dirección al Nuevo Mundo.

Su segundo libro de cuentística aquí reseñado, La procesión de los ardientes, está conformado por diez relatos breves. Entre ellos tenemos: En un lugar de las Indias, El historiador problemático, Los papeles de la academia utópica, A la izquierda del águila, ¿La revolución no tendrá lugar?, Vida sexual angélica, El dios errante, Informe sobre el convento de Santa Cristina, El jeroglífico del alma y, finalmente, el relato que da nombre a su libro de cuentos La procesión de los ardientes. Aquí, en esta serie de relatos, como en los anteriores, Gómez Valderrama se entrega a la búsqueda de un diálogo con la cultura occidental recurriendo a la ficcionalidad. Allí, en sus relatos cortos, tienen lugar temas tan profundamente occidentales como la discusión sobre el sexo de los ángeles, pero esta vez refrescado por la geografía de los Andes; incluso aparecen elaboraciones históricas posibles como la que se narra en El historiador problemático.

Así sucede por ejemplo en el cuento En un lugar de las Indias (1973; 9-19), que ha sido comentado ya por Germán Santamaría, Luís Correa Díaz, Alexander Giraldo y el profesor Alfredo Abad. La historia que narra el cuento de Gómez Valderrama tiene como suceso fundamental un hipotético viaje de Miguel de Cervantes a tierra Americana. Dicho factor, y lo que en tal viaje acontece, le impide llevar a cabo la culminación de su obra maestra El quijote. A su vez, esta narración concerniente a Cervantes se encuentra narrada desde la óptica de Don Alonso, El personaje central de El quijote y, para construir un ambiente de verosimilitud se recurre a referencias textuales; Germán Santamaría ha mostrado, en ocasiones con exagerado tono, como la obra de Valderrama juguetea con la historia al colocar a Cervantes en Cartagena y, así mismo, entablar un diálogo entre Cervantes y Don Quijote, es decir, Don Alonso (cfr. www.revistadiners.com.co/noticiaphp3?nt=25450; Dic 7 del 2007).

Continuando con su obra cuentística debemos señalar que en el libro Invenciones $y$ artificios reaparecen una serie de narraciones ya consignadas en El retablo de maese Pedro y en La procesión de los ardientes. Sin embargo, hay que señalar que también se muestra un cúmulo de nuevos relatos. A continuación haremos mención de la totalidad de textos que componen este libro de cuentos y, posteriormente, realizaremos una breve acotación de las narraciones que no aparecen en los textos anteriores. Así pues, debemos señalar que este texto, Invenciones y artificios, se compone de once narraciones breves, a saber: La aventura de la nieve, La mujer recobrada, ¡Tierra..., En un lugar de las Indias, Cien años de aire, ¿La revolución no 
tendrá lugar...?, El historiador problemático, El dios errante, Corpus iuris civilis, El maestro de la soledad y, finalmente, Los papeles de la academia utópica.

Como puede bien cotejarse con lo escrito líneas atrás, las narraciones que coinciden en los textos, tanto en El retablo de maese Pedro como en La procesión de los ardientes con este texto denominado Invenciones y artificios son: La aventura de la nieve, la mujer recobrada, ;Tierra...! y El maestro de la soledad, En un lugar de las indias, ¿La revolución tendrá lugar...?, El historiador problemático, El dios errante $y$ Los papeles de la academia utópica. Los nuevos relatos consignados en este texto son: Cien años al aire, y Corpus iuris civilis,. En esta serie de relatos Valderrama retorna a la ficcionalidad histórica. Esta vez los personajes son distintos, Santander, Schopenhauer, Stendhal y Don Andrés Bello son algunos de los personajes históricos que, siendo re-pensados por Valderrama, se encuentran ubicados en un tiempo que bien pareciera ser histórico pero que de hecho está mediado por una alta dosis de ficción que Valderrama le imprime a sus narraciones.

Una muestra de lo dicho anteriormente es lo que ocurre en la narración Cien años al aire $(1975 ; 43-54)$, donde se procura un corto relato bibliográfico-intelectual. En él se habla de un encuentro que posiblemente hubiera tenido lugar entre el general Santander y Stendhal en la casa de un escultor llamado David a partir de la reflexión sobre la verosimilitud de los sueños y de su injerencia en lo que varios psicólogos (Freud, Jung y Jaspers) llamarían la vida anímica inconsciente. Empero sucede que, aunque se cree con toda verosimilitud un ambiente propicio para tal encuentro, Valderrama adolece, según lo confiesa en la narración, de la prueba que alguna vez creyó encontrar en el Diario de Santander o de Stendhal. Por lo pronto el relato culmina en la indiferencia de discernir con exactitud si aquello que acontece es con certeza, como el mismo escritor lo plantea al inicio del texto, un sueño o, contrario a ello, algo real pero no probable mediante un testimonio escrito (Cfr. 1975; 43).

Hasta este lugar baste el recuento de las narraciones que ejecuta Pedro Gómez en Invenciones y artificios. Finalmente señalaremos lo que sucede con su libro de cuentos La nave de los locos (1984). Este texto trae a la luz una serie de narraciones en su mayoría muy cortas, que vinculan diferentes acontecimientos históricos con una profunda capacidad imaginativa del autor: el texto se divide en quince narraciones cortas, cuentos, y veinticinco narraciones sumamente breves que a su vez se subdividen en doce Sortilegios y trece muertes apócrifas; estas últimas conforman una unidad que son referenciadas por el escritor como Las muertes apócrifas. Así, para no detenernos en una elaboración sumamente prolija hemos de tomar, como se ha hecho con las narraciones anteriores, los quince cuentos haciendo un comentario general de cada uno y, finalmente, en el orden que hemos dividido las narraciones 
restantes, en Sortilegios y Las muertes apócrifas, procederemos de manera semejante.

En esta obra, La nave de los locos, se dan cita quince nuevas narraciones breves. Descripción e historia de una visita al Museo de Louvre, Responsabilidad de Stendhal en la batalla de Waterloo, Eliezer y Rebeca, Las músicas del diablo, El olvido capital, La nave de los locos, La muerte de Lincohlhn, La cabeza del papa, El espejo profundo, La paloma del Espíritu Santo, Su hora de gloria, Lista de pasajeros del autobús municipal, María a las cuatro de la tarde, La habitante y finalmente Itinerario de un ten crepuscular conforman dicho conjunto. En ellas, nuevamente Valderrama se entrega a los juegos con la historia mostrando así una historia posible a través de la ficcionalización con datos entregados por la versión oficial de la historia.

Así parecen mostrarlo dos relatos: el segundo relato, Responsabilidad de Stendhal en la batalla de Waterloo y Eliezer y Rebeca. El primero de ellos es el reflejo de una de las concepciones de Valderrama sobre la historia. Cierto es que posiblemente la narración, abundante en alteraciones de fechas y citas que no por ello dejan de ser verosímiles, acerca del suceso, nada haya tenido que ver con el acontecimiento como tal. Empero, el hecho de haber sido escrita previamente a la derrota de Waterloo, antes del suceso mismo, irá a condicionar la suerte histórica del Emperador, Napoleón. Ello nos recuerda una vez más lo que en la narración Cien años al aire nos ha dicho:

(...) que la historia se rescribe día a día. Que cada uno la rescribe, a través de esa memoria indescriptible que permite al hombre, tal vez en un solo momento de su vida, estar en una época distinta a la propia, acaso porque necesita no estar solo $(1975 ; 54)$.

La siguiente narración, Eliezer y Rebeca pone de nuevo, ante nosotros, el más viejo tema de la literatura: el amor. En esta narración en donde se construye un relato en pasado, se muestra la travesía de un hombre, Eliezer, destinado a conducir la esposa de Isaac, hijo de Abraham, ente aquel. En este transcurso brota entre Eliezer y Rebeca el amor, un amor que no puede eludir la idea de un fatal deber, de un sino que culmina separando al personaje central de esta historia de su "objeto" deseado condenándolo con ello al destierro, a morir "de hambre y de olvido" $(1984 ; 28)$

Ahora, como lo hemos anotado con antelación, haremos un rastreo de aquello que Gómez Valderrama agrupó bajo el nombre de Sortilegios y Muertes apócrifas. Posteriormente realizaremos un balance de los consignado en estas narraciones para, así, hacer un acopio que nos ayude a formarnos una imagen más precisa de lo que la obra de Valderrama es, al menos, en esta parte de la cuentística. Bajo el rótulo de Sortilegios aparecen diferentes narraciones. Entre ellas se apiñan: El habitante de la torre (1984; 126-127), El tapiz del virrey (Ibíd; 127-128), El castigo (Ibíd), Los 
ojos misteriosos (Ibíd;129), Suma teología (Ibíd;130), Inundación (Ibíd; 130-132) La verdadera historia (Ibíd; 132-134), El sol de la tarde (Ibíd;134-136), Dos fórmulas para la Atlántida (Ibíd;136-138) El estudiante y el filósofo (Ibíd;139-141), Memoria sobre la invencible Armada (Ibíd;141-142), Discusión sobre cementerios (Ibíd;143144). En cada una de estas brevísimas narraciones se pretende ofrecer al lector un relato excesivamente corto de narraciones que retoman diferentes íconos del universo cultural de Occidente: el bíblico Jonás, el sagrado misterio de la Trinidad, La divina comedia, Platón, Kant, La Atlántida, La Armada Invencible y hasta las disputas legales sobre el terreno ocupado por el muerto. Todos estos relatos con la multiplicidad de iconos occidentales que hemos nombrado en este lugar, son reinterpretados y situados en un ambiente en donde su explicación se distancia del hecho heroico o de la platonización del amor, que son el común tópico de estas narraciones expresados de una manera ortodoxa, secular. En conjunto estos relatos nos ofrecen, no una narración verídica o siquiera aproximada sobre lo que el hecho tal y como certeramente hubiera sucedido, sino como hubiera querido el autor que dichas narraciones tuvieran lugar. Por ello Pedro Gómez designa un nombre más atinado como el de Sortilegios para bautizar así este conjunto de narraciones que son un conjuro contra la ortodoxia de lo secular y reiterativo de las historias canónicas de Occidente.

Finalmente, el último apartado de su Nave de los locos es denominado Las muertes apócrifas (1954; 145-147). Conformada por trece decesos fúnebres, Valderrama cuenta, al igual que en las anteriores narraciones, la forma en que posiblemente hubiera ocurrido el deceso de alguno de estos hombres claves para la historia, no sólo de Occidente, sino también para la de nuestra América Latina. Entre ellos se cuenta la posible muerte de Cristóbal Colón (Ibíd; 147-148), Vasco Núñez de Balboa (Ibíd; 148), Napoleón (Ibíd;148-149), Lucrecia Borja (Ibíd; 149151), María Antonieta (Ibíd; 151), El marqués de Sade (Ibíd; 151-152), Simón Bolívar (Ibíd; 152-153), Stendhal (Ibíd; 153), Lenin (Ibíd; 153), La muerte de K. (Ibíd; 154156), Augusto Pinochet Ugarte (Ibíd;156), Mao Tse Tung (Ibíd;157), y, finalmente La muerte del escritor (Ibíd; 157-158).

Así, como puede verse por el recorrido que hasta el momento hemos realizado, Valderrama coquetea en su escritura con otro tipo de narraciones que escapan al relato del mero suceso regional. En esta dirección Valderrama nos sitúa con algunos de los personajes fundamentales de la historia, adquiriendo así un nuevo aire figuras tan caras a nuestra formación espiritual como lo son Sade, Paganini, Goethe o el Bosco que al tiempo fueron emblemáticos emisarios occidentales implicados en la sensibilidad de nuestro escritor. Estos emblemas se afincaron a la reflexión de Valderrama porque ellos mismos eran, cada uno en su tiempo, los mensajeros de 
un nuevo cambio de mentalidad, los heraldos de una nueva forma de entender y organizar el mundo; cada uno de ellos en sus diferentes artes, la pintura, la música o la literatura, dieron en el punto arquemídeo concerniente a las bases de una nueva cosmovisión: el pensamiento liberal ${ }^{40} \mathrm{y}$, tras haberlo hecho, lograron hacer del concepto una espléndida manifestación estética.

Así pues, en relación al "compromiso político" de Valderrama hemos de anotar un par de palabras. Gómez Valderrama, pese a ostentar diferentes cargos de índole administrativa en el Gobierno colombiano, siempre estuvo claro en un postulado: su pensamiento ha de ser profundamente liberal. Pero por dicha forma política de concebir el mundo no puede comprenderse la tradicional forma liberal que en nuestro país hizo carrera durante muchos años, no se puede ver a Valderrama como un hombre que sale a hondear una bandera roja, recientemente decorada, con una L blanca en el medio. Debe entenderse por liberal ese movimiento que, incubado en el respeto a las individualidades, surgido en medio del contractualismo propugnado por Hobbes ${ }^{41}$, Locke ${ }^{42}$, Rousseau ${ }^{43}$, y más tarde Kant ${ }^{44}$, propugna por ese ideal

40. Para observar este cambio en la visión de mundo que no sólo es económico sino también ético y político, es necesario observar dos textos fundamentales para mostrar el desarrollo de este pensamiento de una menara completa, al menos en lo que se refiere a su presentación general: Jardín, André (1985) Historia del liberalismo político, De la crisis del absolutismo a la constitución de 1875. Ed. Fondo de cultura económica, México; y el texto Historia del liberalismo europeo (1944) ed. Pegaso, Madrid, escrito por Guido de Ruguiero.

41. La propuesta política de Hobbes se puede hallar en dos libros fundamentales De cive: Elementos filosóficos sobre el ciudadano (2000) y Leviathan (1935). Los conceptos claves de su propuesta política son tanto el estado de naturaleza, el gobierno civili, el pacto social, el poder y, finamente, el temor que en gran medida es el elemento que hace que los ciudadanos busquen la agrupación como sociedad civil.

42. En lo que concierne a la propuesta liberal de Locke, bien puede observarse dos textos que contienen una clara inspiración hobessiana con sustanciales disputas y una clara herencia de Hooker y Santo Tomás. Dichos textos son Ensayo sobre el gobierno civil (1941) y Ensayos sobre la ley natural (1998). Los conceptos claves que habitan esta postura liberal son: estado de naturaleza, ley natural, gobierno civil, propiedad y trabajo. Este último, concebido como el esfuerzo individual de cada habitante de una ciudad se considera inalienable y es él quien da pie a la existencia de la propiedad privada.

43. Rousseau, de una clara inclinación romántica, concibe al hombre ya no como en el caso de Hobbes homos lopus homini est (el hombre es un lobo para el hombre), sino como un ser bueno por naturaleza y, desde esta concepción de hombre, y sintiendo a la sociedad y a la cultura como una carga pesada e incluso aborrecible para el hombre, Rosseau inculca su concepto clave de contrato social. Para ver la postura contractual de Rousseau se recomienda ver el texto El contrato social (1988) Barcelona, ed. Altaya. Para observar lo que se piensa en relación a la cultura y su concepción antropológica es necesario observar su Discurso sobre el origen y los fundamentos de la desigualdad entre los hombres (1987).

44. Finalmente, por lo que respecta a la propuesta liberal del pensador koningsburguense, debe señalarse que esta se encuentra depositada en textos como ¿Qué es la Ilustración? (2002), Principios metafísicos del derecho (1943) y La filosofía de la historia (1981). En ella juega un papel prioritario la razón y el entendimiento como mecanismo que hace acopio de nuestra forma de concebir el mundo y de comunicarla como seres humanos que nos servimos de la experiencia para andar en la historia, no como simples entes particulares, sino como miembros de una comunidad universal. 
ilustrado de hacer un uso público y prudente de nuestra razón, lo que implica en gran medida la intromisión subjetiva del individuo con su capacidad laboral y, por tanto, avasalladora sobre la tradición y los credos como forma base de nuestra cultura.

De allí, de esta manera de pensar, se desprende toda una cosmovisión liberal. Dicha cosmovisión se afinca en el despertar de una sexualidad y un erotismo que transitan por toda la obra de Valderrama. Ahora bien, no se piense simplemente en usar como símbolo de tal tendencia liberal la mera manifestación de la libido que atraviesa casi toda la obra del escritor; piénsese, igualmente, en la sabia responsabilidad en relación al conocimiento no sólo de la forma en que la escritura es depositada, en la selección del género, de su máscara, sino de cada uno de los contenidos que en la obra de Gómez Valderrama se hallan insertos, como en el caso de la selección de sus personajes centrales, tanto en los cuentos como en la novela. Sí, es bien cierto que el escritor de La nave de los locos ha ostentado cargos como los de ministro de educación, embajador en Rusia, colaborador del Frente Nacional; empero dicho recorrido no obsta para que nuestro escritor deje de señalar a través de sus escritos aquello que en realidad constituye su punto de vista; la cimentación de un pensamiento liberal.

Esta misma ruta de pensamiento, la del respeto por las disímiles particularidades del individuo que se considera moderno, ha de pervivir en otro ejercicio investigativo que explora un género disímil al de la narración breve. El tan elogiado texto, Muestras del diablo, del cual aún perviven resonancias en algún locutor radial de opinión como lo es Alberto Casas. Dicho texto se ha establecido, sin duda alguna, como un texto que no sólo centra su mirada en analizar los cortejos al oscuro mundo de la hechicería o al mundo de la magia negra, sino que se funda como una indagación que es al tiempo un adalid de la defensa de los cultos religiosos de nuestra pluriétnica nación. En Muestras del diablo se aboga por una libertad de pensamiento y de culto que no vino sino a hacerse oficial hasta nuestra consabida constitución de 1991, allí, en torno a lo que se ha considerado "satánico" reposa ya un indicio de ganar para la generación intelectual de la época de Valderrama esa posibilidad de ver otras manifestaciones religiosas, e incluso corporales (en el caso de la desnudez) como aquello que conforma una esfera diferente de la vida del hombre y que no puede excluirse simplemente, como bien lo pensaban la mayor parte de nuestros abuelos, como obra del demonio (Cfr. Gómez, 1994; 13).

Este prejuicio que ataca decididamente Valderrama en sus "satánicas" Muestras del diablo es de vieja data. Tan de vieja data como lo es el mismo padre intelectual del cristianismo y en cuyo libro fundacional, no sólo para el estudio de la historia, sino también para el estudio mismo de la religión cristiana, La ciudad de Dios, se lee 
lo siguiente:

¿Quién sois vosotros para que yo me entregue a raciocinar con vosotros ni de vuestros dioses, cuanto más de mi Dios, que es terrible sobre todos los dioses, porque todos los dioses de los gentiles son demonios y sólo el Señor crió los Cielos $(1940 ; 66)^{45}$.

Como puede observarse aquí, los "dioses de los gentiles", contra quienes habla San Agustín, específicamente los dioses del pueblo romano, son considerados como demonios. No otra cosa hubo de suceder en la mente de quienes habitaban nuestro continente respecto a dicha consideración sobre los dioses foráneos, los dioses de nuestros afrodescendientes, una vez que el marco teórico con el cual se movía el mundo occidental era completamente eclesiástico. Otra evidencia de ello puede fácilmente rastrearse observando que los responsables de reproducir dicho marco teórico, los educadores, eran de corte clerical. Así, esta forma excluyente de ver el mundo, de interpretar los fenómenos de una cultura ajena a la nuestra, respaldado también por esa influencia que nos ha llevado a concebir nuestras ideas políticas en dos colores, era aquello que hacía ver a los hombres de otras épocas no tan lejanas de nuestra historia, el color del día en una dupla que pendulaba entre el negro y el blanco. El matiz, la comprensión del otro, una categoría que ya Europa exploraba tras las secuelas del Nacional socialismo, incluso de una manera clínica, (Jaspers, 2001; IX) era impensable en el universo cultural de nuestra Colombia.

De tal suerte, como bien lo alcanza a reflejar la pluma de Valderrama, el diablo, la noción de la encarnación del mal, no es un hecho verídico. Más bien dicha noción del mal encarnado funciona a modo de cortina para ocultar aquello que en realidad sucede tras bambalinas: una severa persecución política. Ella, en la escritura de Valderrama, debe ser bien entendida como el surgimiento de una voz nueva al interior del pueblo, del Estado, una nueva fuerza que le insufla un aire renovado al mundo: el pensamiento liberal.

$\mathrm{Y}$ es en este punto, justo cuando hemos abordado el universo político de su pensamiento, que es necesario volcar la mirada hacia Los ojos del burgués y el pequeño ensayo Nosotros y la libertad: el primero de estos dos textos, concebido en su estadía en Rusia como canciller, se muestra desde una perspectiva más abierta a la comprensión. Se procura, en este lugar establecer una relación más amable con ese

45. Debe aclararse que el texto se encuentra reproducido aquí tal y como está en la edición de la editorial Poblet. Como puede verse hay un descuido con el signo de interrogación que imposibilita saber hasta dónde se encuentra formulada la pregunta. Por lo demás este tipo de fallas "formales" son recurrentes en esta edición del capital texto del águila de Hipona. 
demonio que atravesaba Europa conocido como el socialismo. Este fenómeno que se conforma como la muestra fundacional del inicio de un nuevo tipo de hombre, el homo sovieticus, hace hincapié en que aquello que se necesita para ejecutar a cabalidad un acto de plena revolución no es, en efecto, un nuevo tipo de Estado ni la toma violenta del poder, es, con mucho, la formación de un "nuevo hombre": el hombre paciente que tenga la calma estoica, al presentarse cualquier adversidad, de esperar con paciencia y al tiempo con una confianza indestructible, la intromisión del Estado en un detalle peculiar de su vida privada con miras a la idea de una satisfacción de las necesidades elementales.

Ahora bien, por lo que respecta a ese breve ensayo denominado Nosotros y la libertad, seguido de Los lotófagos debemos realizar un par de apuntes. El texto, aunque corto, traza un recorrido histórico de la relación política de Colombia con la idea de libertad, una idea que se ha construido, es cierto, a través de la denuncia pública en los medios escritos y, al tiempo, en un esfuerzo mancomunado por mantener siempre vivo el pasado procurando no olvidar, no convertirnos en lotófagos. Así, de esta manera, con una apelación a la memoria, al esfuerzo individual por no dejarla en el olvido, y al unísono como una defensa de la forma base del pensamiento liberal en Occidente es como obra, vida y pensamiento, siguiendo una de las primeras reflexiones de Bajtín confluyen en un hombre: Pedro Gómez Valderrama. 


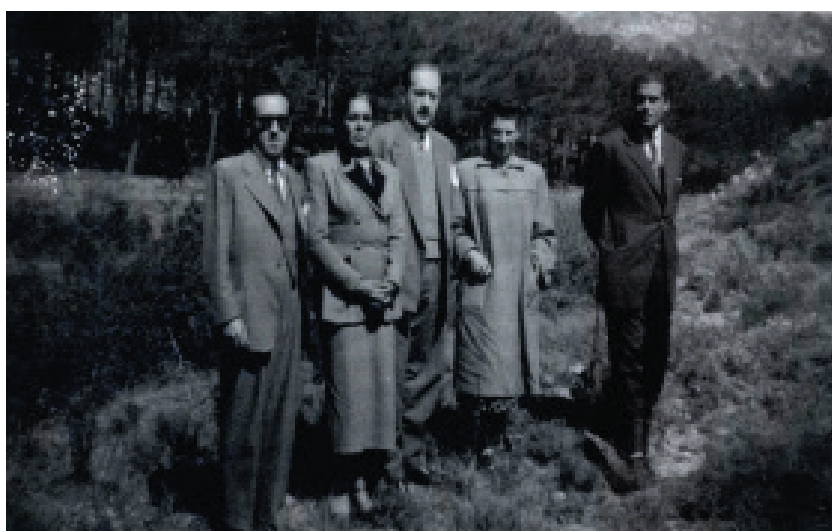

Foto tomada de la revista Universidad de Antioquia (2006; Abril-Junio) Número 284 p. 73

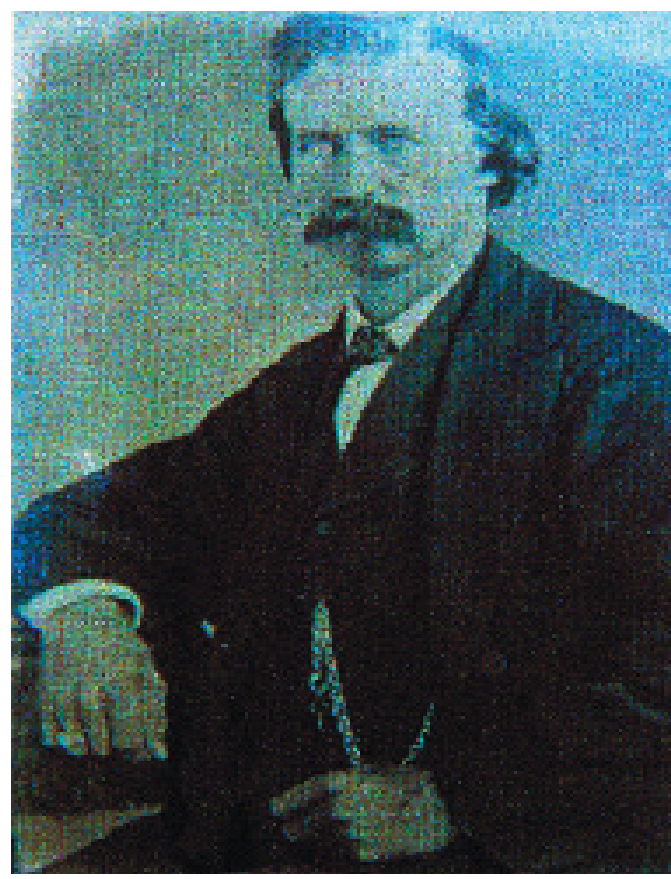

Fotografía de Geo Von Lengerke, tomada de http://fis.unab.edu.co/docentes/olengerke/ geovonlengerke/ Septiembre 26 del 2008 
CAPÍTULO CUATRO 


\title{
El abuelo y Lengerke un diálogo entre lo propio y lo occidental
}

\author{
"Todo lo dicho no niega en absoluto la posibilidad de una \\ confrontación científica de las biografías del personaje y del autor, \\ así como la comparación entre sus visiones del mundo, \\ procedimiento útil tanto para la historia de la literatura \\ como para un análisis estético".
}

Bajtín

Si bien es cierto que nuestra hipótesis a demostrar es que en La otra raya del tigre de Pedro Gómez Valderrama, a nuestro juicio, pretende un diálogo de tradiciones es necesario mostrar cómo aparecen tales tradiciones en la obra del escritor de Nosotros y la libertad. En nuestra reconstrucción, por no decir relectura del texto de Valderrama, apuntamos que dicho diálogo se ejecuta en la medida en que aparecen en escena dos personajes que son fundamentales para la construcción de la obra: el abuelo, Juan de Dios y Geo von Lengerke. Dichos personajes establecen esa posibilidad de dialogar en relación a una diferencia cultural y, con ello, de concepción de mundo. En las líneas que siguen mostramos cuál es, a nuestro juicio, la concepción de mundo del abuelo y, posteriormente realizaremos algunos apuntes sobre la mirada de Lengerke. Debe recalcarse que hemos asumido la forma de ver el mundo del abuelo como un indicio de una tradición sumamente propia, mientras que la del alemán, Lengerke, la hemos tomado como indicio de una cultura occidental.

Nótese que hemos hecho referencia al término concepción de mundo. Este término tomado del pensamiento psicológico de Carlos Gustavo Jung y Karl Jaspers hacen alusión a la peculiar configuración de mundo de cada uno de los seres humanos. Aquí, en este lugar de nuestra indagación dejaremos de lado el método hermenéutico, el cual nos ha servido para realizar una aproximación tanto al pensamiento como a la obra de Pedro Gómez Valderrama y utilizaremos otro método de análisis literario con algunas variantes: la psicocrítica. Tal procedimiento de análisis literario usualmente ha tenido como referencia el método psicoanalítico freudiano y sus relaciones entre el consciente y el inconsciente. Así parece mostrarlo Charles Maurón (1997) en su texto Psicocrítica del género cómico cuando señala: 
“(...) La psicocrítica es un método de análisis literario. Empírico en sus operaciones, se propone descubrir y estudiar en los textos, las relaciones que probablemente no han sido pensadas ni siquiera queridas de forma consciente por el autor (...)" (p. 11).

Así entendida la psicocrítica, esta disciplina se encargaría de hacer un examen del inconsciente del escritor en una obra cualquiera a partir de la superposición de textos, es decir, del examen de los diálogos de los personajes que el escritor pone en juego en la obra.

No obstante este proceder nos parece un poco frágil y, sobre todo, poco prudente para nuestro propósito. Por ello proponemos en este lugar, a propósito de la psicología de Jaspers, y aún, la de Carlos Gustavo Jung ${ }^{46}$, un esquema conceptual para analizar este mismo objeto de estudio, es decir los diálogos de los personajes, procedimiento que por lo demás ya anuncia Bajtín (Cfr. 1985; p. 13-14). Partiendo de estos y, sobre manera de las caracterizaciones de dos personajes de La otra raya del tigre Juan de Dios y Geo von Lengerke, queremos observar cómo, siendo estos personajes analizados con el marco conceptual de una psicología comprehensiva, establecen sus relaciones y cómo se desenvuelven dinámicamente en la única novela de Pedro Gómez Valderrama.

Tradicionalmente el método de la psicocrítica, como ya lo habíamos anotado, apunta en una dirección diferente, puesto que labora con el esquema conceptual suministrado por Freud (cfr. Maurón, 1998; p 68-69). Maurón señala: “(...) La validación de la metodología psicocrítica exigía ser aplicada a obras muy diversas habiendo sido ya aplicada a la personalidad del autor, la época y el género (...) ". Empero, lo que en este lugar se propone es utilizar la misma psicocrítica con un contenido conceptual y fin diferente. Distanciado del esquema freudiano y con miras a esclarecer las diferentes constituciones psicológicas de los personajes, usando para ello el concepto concepción de mundo, esperamos esclarecer la manera en que dos tradiciones entran a jugar un papel primordial en la obra citada de Valderrama.

Debemos aclarar que el concepto concepción de mundo, usado por Bajtín, como ya lo anotamos, es acuñado por la reflexión psicológica de Karl Jaspers y Carlos Gustavo Jung, con un matiz propio. De abolengo husserliano, dicho concepto designa el conjunto de vivencias y, con ello, la forma de apropiarse de una tradición

\footnotetext{
46. Es de anotar que este procedimiento no es nada original. En nuestra Maestría en Literatura ya se ha presentado un trabajo que va en esta dirección a propósito de la psicología de Jung, pero sirviéndose de otras categorías psicológicas; me refiero al texto Ser y acontecer del Nuevo Mundo, el simbolismo mítico en la narrativa de Germán Espinosa (2006), elaborado por el profesor Julián Alberto Naranjo.
} 
de manera sumamente individual de un sujeto determinado (para nuestra situación, alguno de los personajes de la obra de Valderrama) y sus disímiles relaciones con el objeto (es decir con las cosas de las que se sirve el personaje, incluso su propio cuerpo para ejecutar un acción). Por ello, en las páginas que vienen, se dará prioridad al juego de vivencias que aparecen relatadas dentro de la obra de Valderrama tanto en el personaje Juan de Dios como en Geo von Lengerke.

Observemos lo que al respecto señala Jung, acerca del concepto pero esta vez de una forma adjetiva.

El psicoterapeuta tiene que conocer no sólo la biografía personal de su paciente, sino también los presupuestos espirituales de su entorno espiritual próximo y remoto, donde las influencias tradicionales y cosmovisivas desempeñan una función importante y, a menudo, decisiva $(2006 ; 36)$.

De tal suerte la cosmovisión que se añade aquí a la tradición es el concepto mediante el cual podemos, por decirlo de alguna manera, ahondar en la visión de mundo particular de los seres humanos, haciendo de la psicología, en consonancia del saber literario, y más aún de la hermenéutica, un saber más comprehensivo. Ahora bien. Puede señalarse que, como bien lo anota el inicio de la cita, esta referencia se hace efectiva para un análisis psicoterapéutico, es decir, para trabajar con personas de carne y hueso y no con personajes; empero, para salir avantes de este impase Maurón señala:

¿Pero cómo separar conflicto dramático y conflicto psíquico? Si el primero pone en juego personajes y el segundo situaciones, es preciso que el autor o el espectador interiorice los personajes y viva o reviva en sí mismo el sistema de relaciones para poder apreciarlo $(1998 ; 68)$.

De tal manera, como un ente con vida propia, es como debe entenderse un personaje, al menos en su construcción psicológica, con un haz de relaciones que le son propias, que conforman su visión de mundo.

Empero, no se piense que este concepto de visión de mundo parte de un mero impulso subjetivo, de un quehacer individual. Jung indica:

Cuando la era gótica, que se había alzado con un impulso unánime hacia el cielo aunque apoyándose en una base geográfica y en una concepción del mundo estrechamente circunscritas, se derrumbó, quebrantada por la catástrofe espiritual de la Reforma, la ascensión vertical del espíritu europeo se vio frenada por la expansión horizontal de la conciencia moderna. 
La conciencia no se desarrolló ya en altura, sino que ganó en extensión geográfica e intelectualmente. Fue la época de los grandes descubrimientos y del ensanchamiento empírico de nuestras nociones de mundo (1986; p.7).

Así, como puede observarse el concepto de cosmovisión o concepción de mundo hace referencia a esa suerte de ideas que conforman, lo que hemos denominado líneas atrás el espíritu de una época. De igual manera lo indica Jaspers cuando señala:

Cuando nosotros hablamos de concepciones del mundo, queremos decir ideas, lo último y lo total del hombre; tanto subjetivamente, como vivencia y fuerza y reflexión, como objetivamente, en cuanto mundo conformado externamente (1967; p. 19).

Así pues, es necesario entender que el término concepción de mundo y los respectivos sinónimos que ya hemos señalado, indican el acervo cultural en el que el hombre habita; mostrar que ese conjunto de ideas hacen parte de un pensamiento liberal al interior de dos de los personajes que gravitan en la obra de Valderrama es el propósito de las líneas que vienen.

\section{El abuelo, una tradición sumamente propia}

Desde las primeras páginas Gómez Valderrama caracteriza al abuelo con una actitud fundamentalmente madura, contemplativa. Así, lejos de establecer una acción que atraviese la escena, que ponga al personaje a jugar un papel protagónico, Pedro Gómez nos muestra al abuelo simplemente como un espectador "pasivo", que sólo contempla aquello que ejecuta el universo que le hace compañía. Gómez siempre habla del abuelo como un hombre distante del mundo circundante "el abuelo mira hacia la proa" (2003; 16), escruta las aguas $(2005 ; 18)$, señala la selva (2003; 19). De tal suerte que, desde sus primeras apariciones, encontramos sólo al hombre que medita, observa y contiene su juicio y su acción antes de emprender cualquier empresa, aspecto que indica, psicológicamente, la posesión de un alto grado de madurez.

Empero, no es sólo el silencio adjunto a la observación de los hechos lo que caracteriza la madurez del abuelo. En su mente hay ya un acervo impresionante de conocimientos al lograr distinguir con precisión, lo que es propio de aquello que no lo es. Valderrama anota:

La respiración lenta, el aire tan puro, del que alguien decía, "como el aire griego"; el abuelo, menea la cabeza: son efusiones líricas; el aire de estas 
alturas es distinto, es un aire de cóndores, de oidores y arzobispos arropados contra el hielo del altiplano $(2003 ; 21)$.

Aquí, como bien puede observarse, existe el esbozo de una tradición que se asume como propia, pero que se reconoce en la diferencia. La diferencia se teje en contraposición con el "aire griego"; este, el nuestro, a diferencia de aquel, es sin duda distinto: los cóndores, los arzobispos y el altiplano, no son más que muestras sumamente tangibles de aquello que no puede ser griego ni por la cultura, en el caso de la figura del arzobispo, ni en lo que respecta a la vida natural ni a la geografía de un país; en lo que corresponde a los cóndores y el altiplano.

Pero aún hay más. En una descripción del paisaje a través de la percepción del abuelo Gómez Valderrama señala lo siguiente:

El abuelo ve, uno a uno, los pueblos desde la cima oscura; atrás Guaduas, aquí Villeta, la confusión de los mercados, los grandes sombreros en punta, las ruanas azules con vuelta roja, las casas blancas, las iglesias humildes, y luego, los pueblos del altiplano (Ibíd; 27).

Puede observarse en estas líneas cómo el escritor de La otra raya del tigre nos enseña esa concepción del abuelo sobre lo propio, entendida ella a través del mutismo del personaje en relación con la región geográfica. Incesante en su pluralidad de formas vegetativas, el abuelo muestra esta descripción de lo propio afincada en lo autóctono, a lo que es, como ya lo habíamos señalado con anticipación, lo propio de la tierra. Empero, esta mirada del abuelo sobre el mundo que tiene por objeto una concepción de lo propio no culmina en lo autóctono pese a que las descripciones sobre la geografía de la región son constantes.

Más allá de reducir la perspectiva de lo propio a lo estrictamente autóctono, Pedro Gómez, de una forma magistral narra la aparición de un gesto que muestra ese enfrentamiento entre dos concepciones de mundo, en donde precisamente la concepción de mundo del abuelo toma distancia de la foránea. "La sombra del abuelo cerro los ojos indulgentes cuando Lengerke, urdido de la necesidad sexual, acometió a las mozas campesinas, sin parar mientes en el sitio, ni siquiera en el recato" (Ibíd; 60).

Como puede apreciarse en las anteriores líneas, este cerrar los ojos que con maestría narra Valderrama, al ver a Lengerke asechar a las campesinas de la región y consumar tal asecho, no deja de mostrarnos una concepción de mundo que no es compartida: el abuelo dista de estas prácticas sexuales libertinas del alemán. El valor del sexo ya no sólo como mecano que tiene por objeto último la necesaria 
reproducción sino entendido este como forma de comunicación con el mundo, con el otro género, con la mujer, objeto de deseo y al tiempo, ser humano deseante, es algo que el abuelo dista en su formación espiritual de compartir.

Víctima de una educación mediada por la visión clerical potestativa de un régimen colonial, eco del absolutismo europeo y, al tiempo, de un autoimpuesto, rígido, código moral que expresa ya un distanciamiento del saber dogmático y que es por esencia liberal (cfr. Guido de, 1994; p. XXIX), el abuelo se distancia de la exposición del cuerpo a la luz, más aún de la exposición del acto sexual de una manera pública. El sexo, sea este entendido en su actual reducción al coito o, simplemente, a la contemplación del cuerpo desnudo es, para el abuelo, como para la larga tradición occidental mediada por la enseñanza clerical, no obstante con el matiz propio para el abuelo ya indicado, un elemento de pública condena, de señalamiento, incluso de acusación de brujería. Para el abuelo, hay que recordarlo, la bruja tiene la seria virtud de hacer perder al hombre, de enajenarlo, al tiempo que puede brindarle su libertad; es ello lo condenable, la pluralidad indecisa en que la brujería se mueve, no precisamente su oscuro revestimiento (cfr; 2003; 190).

Cabe hacer énfasis en que, no por ello, puede pensarse la imagen del abuelo en la novela de Pedro Gómez como un personaje evidentemente dogmático. Ello no puede ser de ese modo en la medida en que no se alcanza a apreciar en el personaje una condena enérgica a los actos del extranjero de pelos rojizos respaldado por un claro adoctrinamiento clerical. Hay que recordar que el abuelo manifiesta un enérgico distanciamiento con el clero y la imagen de la iglesia, como también lo hubo entre los liberales radicales y el clero; así lo registra la pluma de Valderrama:

(...) Cómo hacía de esto algunos años, ya el cura se lo había perdonado, pero lo que no le perdonaba era que no fuera a misa, y si tenía que hacerlo por boda o entierro, se quedara de pies durante la elevación. Pero don Juan de Dios no se inmutaba, tenía su propio credo moral, más severo, y ponía en su observancia igual intransigencia que en los principios políticos (2003; 136).

De tal suerte, distanciado del clero, pero al tiempo respetuoso a él debe comprenderse la visión de mundo que el personaje Juan de Dios ejecuta. De igual forma debe asumirse la actitud del abuelo como una actitud tolerante con ese otro tipo de comportamiento que encarna Lengerke, una mentalidad de empresa, de progreso, de valoración del trabajo y la propiedad privada, una mentalidad, en el pleno rigor de la palabra, liberal.

Aquí debemos detenernos un momento. En cuanto a la idea de lo que significa la libertad y, con ello, el pensamiento liberal para el abuelo, Valderrama, haciendo 
narrar a su abuelo, teje un bello párrafo:

La libertad, pensaba, toma formas extrañas, la mujer es una de ellas, tal vez la definitiva. Muchos de esos hombres mataron por eso, y por eso la perdieron. La selva, pensaba, es otra forma de libertad, letal como la mujer. Pero tal vez el peor destino de estos hombres, su máxima condena, es la de trabajar amarrados, encadenados en el camino, que es la expresión de la libertad, la manera que tiene el hombre de arrancarse de lo que lo sujeta y lo asfixia. Cuando los globos aerostáticos se hayan perfeccionado y permitan, como lo cuenta Julio Verne, descubrir nuestras fuentes del Nilo, el mundo cambiará más todavía, porque el hombre tendrá maneras aún mayores de ejercer la libertad $(2003 ; 161)$.

Puede verse aquí como la libertad, así lo indica Valderrama, es una idea que no puede ser lograda con violencia; es el camino abierto que el progreso facilita, es la posibilidad no sesgada que nos abre el horizonte hacia la comprensión de lo otro, de la diferencia.

Pese a todo lo ya señalado sobre este enigmático personaje y algunas de sus concepciones, hay un cúmulo más de indicios para desentrañar la elaboración de este que pueden anotarse. Juan de Dios conoce muy bien, a diferencia de Lengerke, esos arcanos de la sabiduría popular y no los deja de lado al momento de explicar un fenómeno. Así lo relata la pluma de Valderrama cuando coloca a Lengerke inmerso en la tierra para cubrirse de los mosquitos y del bochorno nocturno de nuestro trópico:

Pronto están sepultados en la arena, la Nodier quiere hacerlo y metros más allá, ella y Lengerke dejan sus vestidos y se sumergen en la arena fresca, sepultados hasta el cuello, hasta el siguiente día; mientas pasa la noche y dormitan sienten el silencio del tigre, pero ya el alba aclara, rosada, violeta e increíble, el perfume macerado de la selva tiene toda la gama desde la flor hasta la descomposición, el agua les quita la arena, y están otra vez tumbados en el horno del champán, cinco, siete días alucinados de calor y desesperación, hasta los turbiones de Honda donde ayudan a la maniobra para no naufragar, y por fin en la tarde ven el descampado, las casas españolas, la triste y la alegre, la ciudad donde todo el río comienza y acaba, y allí termina el primer toque del dios, y el abuelo los mira y piensa que ninguno de los dos sabe que ese contacto marca para siempre (2003; 19-20).

Tal y como puede verse en esta cita, cuya extensión es inexcusable, en sus últimos dos renglones aparece aquello que veníamos anunciando: ese saber del abuelo que 
no es propiamente un saber emanado de las ideas racionalistas de la Ilustración, sino más bien del Iluminismo ${ }^{47}$, se manifiesta. No se puede entonces decir que pese a la agudeza en la observación de Juan de Dios haya que señalar que su espíritu entra a comulgar con un saber, en exclusiva, científicamente demostrable, con un pensamiento rigurosamente liberal. Juan de Dios sabe de las fuerzas que de la tierra emanan y que al proteger un cuerpo con su arenosa capa, esta ya no lo abandona.

Esta apertura de mente de Juan de Dios se encuentra datada por el mismo Lengerke de una manera indirecta. Hablando con Vicente, al que podríamos considerar como el "imbécil" del pueblo, el alemán anota:

Tengo amigos aquí. Mis amigos más íntimos son tal vez colombianos. Tú los ves, andas con ellos, les trabajas para sus casas. Es curioso que viviendo circunscritos a su tierra, sin embargo, tengan miradas tan abiertas. Debe ser la independencia, todo lo que hubo que superar al salir de la dominación hispana. Salvo Anselmo, los demás no han salido del país, y casi ni de Santander. Es la aventura que no todos quieren tentar. Yo hablo con ellos, me sorprendo de las cosas que conocen, de la manera como piensan $(2003 ; 89)$.

Así este aparte de la obra se muestra como un claro ejemplo y al tiempo una justificación de por qué hemos escogido a Juan de Dios para ser el puente que entabla el diálogo con Europa, con la cultura de Occidente a través de Lengerke. Juan de Dios, lo relata Gómez por boca de Lengerke, es un hombre que aunque reconoce lo propio, aunque se encuentra afincado a la tierra, es de mente abierta para comprender lo otro, lo diferente a sí mismo. La pregunta que ahora debe hacerse es ¿Cómo abre su mente Juan de Dios, una vez que no ha salido nunca de su tierra, al conocimiento de otras mentalidades? Tal pregunta es solucionada en el capítulo IV subcapítulo VII de La otra raya del tigre en donde hay una extensa descripción de este enigmático personaje.

En primera instancia debe señalarse que Juan de Dios es un hombre que gusta del silencio y, por tanto, de la lectura (cfr. Valderrama 2003; 130). Esto claramente lleva en la construcción sicológica del personaje a hacerle gustar de una conversación fundamentada en el cimiento de la formación espiritual de Occidente y que, por ende, Juan de Dios sea presentado como un hombre "medianamente" culto. Su cultura no se ha labrado a través de le excelsa educación de institución, ella se ha acribado en las arduas faenas de la autodidaxia, de la consulta en solitario de los diferentes textos

47. Un rastreo de estas ideas que hacen una clara alusión a un pensamiento mágico, puede encontrarse en el texto La palabra como provocación. Magia, versos y filosofemas (2008; p 28-34) de los profesores Carlos Rincón y Julián Serna. 
que circundan la formación cultural de Occidente, aspecto que recuerda el postulado kantiano y, a la vez la consigna liberal sapere aude! $!^{48}$. La gramática francesa en la autoría de Ollendorf, la literatura de Victor Hugo, Lamartine, Michelet, Dumas, Julio Verne, e incluso su consideración sobre el demonio influida por la lectura de Bataille configuran un pensamiento, una concepción de mundo que pese a regocijarse con los amplios y agrestes senderos de nuestra selva, entablan diálogo con una tradición foránea.

Pero quizás de los contenidos de esa cultura foránea, la idea que más atormente a Juan de Dios sea la de progreso. Así puede mostrarse en las siguientes líneas:

Los misterios de Eugenio Sue y de Alejandro Dumas le cayeron bajo los ojos que descifraban el francés, con los libros de un autor nuevo llamado Julio Verne, cuyas obras son la maravillosa anticipación del Progreso, en el cual el abuelo cree con "P" mayúscula (Ibíd; 134).

Sí, esa idea de progreso, a la cual ya habíamos hecho alguna alusión, emanada de la visión tecnicista del hombre, la cual deslumbró a los habitantes del siglo XIX, es aquello que roba el sueño a Juan de Dios. La maravilla de la técnica sobrepuesta a la incapacidad de dominio del hombre no deja de ser una idea que ronda la cabeza del abuelo y que, en torno a ella, labra todos sus esfuerzos.

De tal forma es que hay que ver en Juan de Dios un indicio de lo que a juicio de Valderrama sería lo sumamente propio. No sólo porque en el abuelo se hace notorio un claro sentimiento de pertenencia a nuestra historia, el cual se deja ver en el conocimiento que de ella tiene, tal y como lo narra Valderrama en innumerables partes (cfr. 2003; 223) sino en el acto de maravillarse con fervor por ese gran misterio que es la vida humana. Así aparece relatado por Valderrama:

Al conservar en alcohol el cuerpecillo del hijo fallecido, de Juan José, como le llamaba siempre, le parecía que prolongaba la existencia de un ser, antes de desleírse en la nada. Y a la vez, enseñaba sus principios a los otros hijos asombrados. A veces observaba a través del cristal el feto, y parecía que sacaba de allí profundas lecciones, como un naturalista empírico que estuviese analizándose a sí mismo. El abuelo Juan de Dios se sentaba a contemplarlo muchas veces, en esas horas después de las cuatro de la tarde a

\footnotetext{
48. Esta expresión comúnmente se ha traducido por algunos de los pensadores que creen decididamente en la razón así: "ten el valor de servirte de tu propia razón” (Kant, Emanuel ¿Qué es la Ilustración? en Paradoxa marzo 2002, número 3, p. 45) empero la frase, en una interpretación literal, sólo quiere señalar lo siguiente: "saber por sí mismo". En esta frase se muestra como el saber, un verbo en infinitivo, sapere, cómplice de las posturas universalista del siglo XVIII, puede ser adquirido por el esfuerzo del ser humano particular, aude.
} 
repensar el misterio de la vida y de la muerte (...) (Ibíd; 137).

Así, como un hombre que es sensible al misterio de la vida tanto como al saber consignado en los libros, como un hombre que se despierta a sí mismo la capacidad de asombro al intentar comprender el mundo de una manera consciente pero también escuchando el llamado de una sabiduría popular; como un ser humano que se labra una moral propia alejada de una concepción clerical a ultranza, pero también que escapa al dogmatismo de la ciencia, es que Juan de Dios puede considerarse en la única novela de Valderrama como un fuerte indicio de la idea de lo propio afincado a un pensamiento liberal.

\section{Geo von Lengerke, la mirada de Occidente}

Valderrama ha tenido muy claro cuál ha sido la mirada del extranjero al llegar a tierras del Nuevo Continente. La fuerza de la esperanza impulsa la llegada del extraño al escuchar los relatos que sobre esta nueva tierra se tejen. Lengerke, como Juan Rodríguez Bermejo, el personaje central del afamado cuento ¡Tierra..!, no fue ajeno a tal espejismo de mundo, un mundo que le habría de brindar resguardo y las posibilidades de hacer empresa y, por qué no, encontrar esa otra mitad que Platón indicó en El banquete a través de un prestigioso comediante del siglo $\mathrm{V}$ a. de $\mathrm{C}$.

Una de las descripciones de Lengerke nos la ofrece también Henao Restrepo al señalar que:

Geo von Lengerke llega a tierras americanas, a instalarse en el Estado soberano de Santander, en donde lleva a cabo de manera muy sui géneris el proyecto liberal en medio de recios conflictos con la vieja herencia liberal de cuño ibérico. Corriente arriba, por el Río Grande del Magdalena, asistimos a todas las peripecias de este Fausto en los Trópicos. Por sus emprendimientos en la construcción y mantenimientos de caminos y sus actividades comerciales que conectaron con Santander y el país con los centros internacionales (...) $(1999 ; 96)$.

Esta imagen de Lengerke que bien corresponde a la perspectiva histórica de la novela más no a lo que de hecho se ha comprobado por la historiografía (cfr. 1998. Nota número 11) muestra una imagen de Lengerke tejida a través de las obras empresariales. Estas, las obras construidas por Lengerke, los caminos, el comercio, el cultivo y la explotación de la quina y la caña de azúcar, es bien cierto, son importantes a nivel macro pero, en efecto, lo son más, para nuestro análisis, a nivel micro. Observaremos en este aparte algunas de esas obras que ponen de manifiesto una concepción de mundo, lo que hemos denominado aquí, en gran medida, una 
tradición que es por completo ajena a la que posee el personaje Juan de Dios pese a que su mentalidad, como lo hemos visto hace poco, es un ejemplo atípico de lo que se entiende por una mentalidad colonial.

Hay que señalar que en efecto el talante de Lengerke, su estructura psicológica como personaje de la novela se manifiesta de una manera voluptuosa. Lejos de la mera contemplación, Lengerke, aparece inicialmente como un hombre joven, se caracteriza por tener una iniciativa que lo lleva a alterar el paisaje apenas al tocar nuestra tierra al dispararle a un caimán (cfr. Ibíd; 15-16) pero también al asechar a las niñas Santa Cruz y compartir su camarote con la señorita Nodier. Estos indicios muestran, como ya lo anunciábamos, la configuración psicológica de un personaje con un talante transformador, trasgresor, que se manifiesta a nivel macro en la consolidación, o por lo menos su intento, de grandes proyectos de orden social.

Esto mismo, esa volición que caracteriza su espíritu se hace presente desde el inicio del texto. Ya al iniciar la obra nos encontramos con una sucinta descripción de Lengerke que se extiende a lo largo de ese subcapítulo. Se lee en Valderrama

Dijo que cuando dejó el barco en Santa Marta, se sintió físicamente perdido entre la selva, ahogado por la explosión verde; pero que al segundo día, comenzó a buscar y encontró que la sola forma de dominar el paisaje era abrirle caminos por un lado, por otro, para extraerle toda la leche de sus frutas $(2003 ; 7)$.

La presentación de Lengerke, la forma en que al observar el universo que ahora, una vez alejado de Europa, lo acoge, haciendo una transformación idealmente para su propio beneficio es ya un claro indicio de su capacidad volitiva. Sus intenciones que luego se verán cumplidas a lo largo de la obra, muestran en conjunto ese ímpetu voluptuoso, propio del extranjero que ve nuestra tierra como tierra fértil, apta para comenzar, si se quiere, una nueva vida. Así como lo muestra la cita ya anotada, en medio de esa explosión verde de selva virgen Lengerke ve la posibilidad de violarla, de abrirle caminos, de penetrar su tupido follaje con el fin de instaurar ese flujo comercial que ha de resultarle benéfico. Empero pese a haber anunciado ya en el acervo de obras a nivel macro que construye Lengerke, ahora debemos acabar de mirar que es aquello que guarda en mente. Para tal propósito es necesario ejecutar un acercamiento a lo que bien pueda entenderse como su cultura, es decir, a la memoria colectiva de una humanidad que se manifiesta en las ideas que un hombre, en este caso Lengerke, pone en juego al labrar su propia existencia. En tal dirección aparecen algunos indicios en su equipaje 
En su portafolio, reposaban las cartas de crédito de los banqueros de Bremen y de Hamburgo, ya levemente deshojadas en Bogotá, al lado de algunas partituras para piano, escogidas al azar de su propia aficción, inútiles ahora: Schubert, Mozart, Beethoven, Wagner. De la caja de libros selecciona en la memoria los Cuentos fantásticos de Hoffman, la edición francesa de El judío errante de Eugenio Sue, que le acompañó en las horas de la travesía, y el Ivanhoe de sir Walter Scott (2003; 45).

De esta manera puede hacerse notoria la forma en que nuestro personaje da indicios de poseer una formada voluptuosidad al tener entre sus haberes música del romanticismo alemán; esta se caracteriza por los altos tonos y los ritmos discontinuos que reflejan el movimiento pasional del alma humana afín al talante de Lengerke. Ahora bien, puede alegarse que en Mozart los cambios de tono no se hacen de una manera intempestiva, empero existen unos cambios de tonalidad escalada que reflejan, de una manera sublime, la forma en como deberían moverse nuestras pasiones. En cuanto a sus lecturas ellas son de diversa índole: especialmente llama la atención que entre ellas se encuentre el propio forjador de la novela histórica, Walter Scott, pero también, y esto es lo que más sorprende, hay una identificación con el Fausto de Goethe, con ese hombre que al unísono es ángel y demonio (cfr. 2003; 86).

Tal vez de allí, de su mirada voluptuosa del mundo, provengan las costumbres atípicas para Juan de Dios: "En esas reuniones se sabía que bebían los licores que importaban y los que el país producía, y que "todos hacían el amor con todas", según informaba en el atrio de la iglesia una espantada devota, poseída del escándalo" $(2003 ; 72)$.

El licor y el sexo se instauran como prácticas que no son exclusivas de un sector marginal de la sociedad; ambos constituyen espacios que el individuo gana en aras de su libertad, una libertad que es una doble emancipación. De un lado se encuentra la emancipación del cuerpo, de su mente, al ser concebido el primero ya no como un instrumento de suplicio afín de purificar un pecado original, potestativa del absolutismo, sino que se torna un elemento de comunicación espontánea con el mundo. De otra parte, el licor se instaura como ese aliciente que excita al cuerpo tanto como a la mente para que realice lo que por temor había tenido almacenado, para que experimente lo que la moderna psicología ha denominado abreacción (Cfr. Jung, 1972; 19).

Esta idea de darle reconocimiento social al licor y al sexo como elementos fundamentales para la configuración espiritual de un hombre libre, lo lleva a instaurar un prostíbulo que luego adquirió nombre, se denominó Puerto Infantas. Aquí, como en algunas de sus obras cuentísticas, es evidente la conexión entre Valderrama y 
Freud en el punto esencial de la represión sexual sublimada en actos violentos del hombre, se lee en Valderrama:

El primer síntoma lo conoció Lengerke en uno de sus viajes de inspección, en un paraje particularmente arisco. De pronto, por un encontronazo sin importancia asomó la reyerta entre dos hombres, que durante una hora se destrozaron a machete sin que nadie pudiera acercarse, sin atender al propio alemán que se acercó a separarlos a riesgo de un mandoble.

Hablando luego con Strauch, la dijo: -Lo que tienen estos hombres es falta de mujeres. Hay que hacerles un pueblo con putas- $(2003 ; 155)$.

De tal manera, a pesar de las prédicas eclesiales que se labraban desde el púlpito en contra de este atentado contra las "buenas costumbres", se gana una libertad más para el hombre: se muestra la vida sexual como algo que debe ser reconocido, dignificado, e incluso institucionalizado a fin de ganar un hombre libre, en palabras de Valderrama, un hombre pleno.

Pero no sólo esta libertad sexual se coloca de manifiesto como una idea proveniente del otro lado del mar. Un cúmulo más grande de ideas se deja ver en una cita un poco más breve. Valderrama anota, haciendo narrar a Lengerke, lo siguiente: "Cuando vine, soñaba con el mito del buen salvaje. Aspiraba a llegar a la naturaleza, incorporarme a ella, regresar al estado natural. Todo lo que le oí al viejo Humboldt. Realizar a Rousseau, los sueños liberales" (2003; 121).

Así como se muestra en el aparte cifrado, Lengerke, al haber oído las narraciones de Humboldt sobre nuestra tierra, y al haber confiado en el espíritu romántico de Rousseau al considerar al hombre un ser bueno por naturaleza, incorrupta por la sociedad, Lengerke pretende ejecutar una segunda iniciación en su vida tras haber manchado con sangre su pasado en Alemania. El agua lustral, selvática, de nuestra tierra será el baptisterio en donde se oficialice, presuntamente, así lo quiere Lengerke, su nueva vida.

De esta manera, como portador de una serie de ideas que no comulgan con una mentalidad colonial es que se construye la imagen de la cosmovisión de Lengerke. Sus ideas emanadas del cruce entre el romanticismo francés, el strum und drang alemán y las ideas políticas de la Ilustración hacen de este personaje un indicio de aquello que comienza a extenderse como un virus por toda América latina: el pensamiento liberal. 
Es aquí, en este punto, donde el diálogo entre la cosmovisión de Juan de Dios y Lengerke, entre la tradición propia y la occidental se entreteje. Los ideales liberales impulsados por la fuerza del comercio que Lengerke pone en juego hace que los caminos, los senderos de la libertad, se abran a Juan de Dios. En Valderrama se lee: "La cólera se equipara al orgullo satánico pero la verdadera naturaleza es la soberbia misma. Le parece que los espíritus de las gentes, son, también como la tierra y que también ha logrado abrirle caminos y establecerles puentes (...)" $(2003 ; 149)$.

Queda pues claro que tanto Lengerke como Juan de Dios más que vías de acceso al comercio, más que una raya más al tigre santandereano, lo que promueven es abrir caminos hacia nuevos horizontes, ensanchar las posibilidades de una comprensión de mundo bajo la tutela de la libertad.

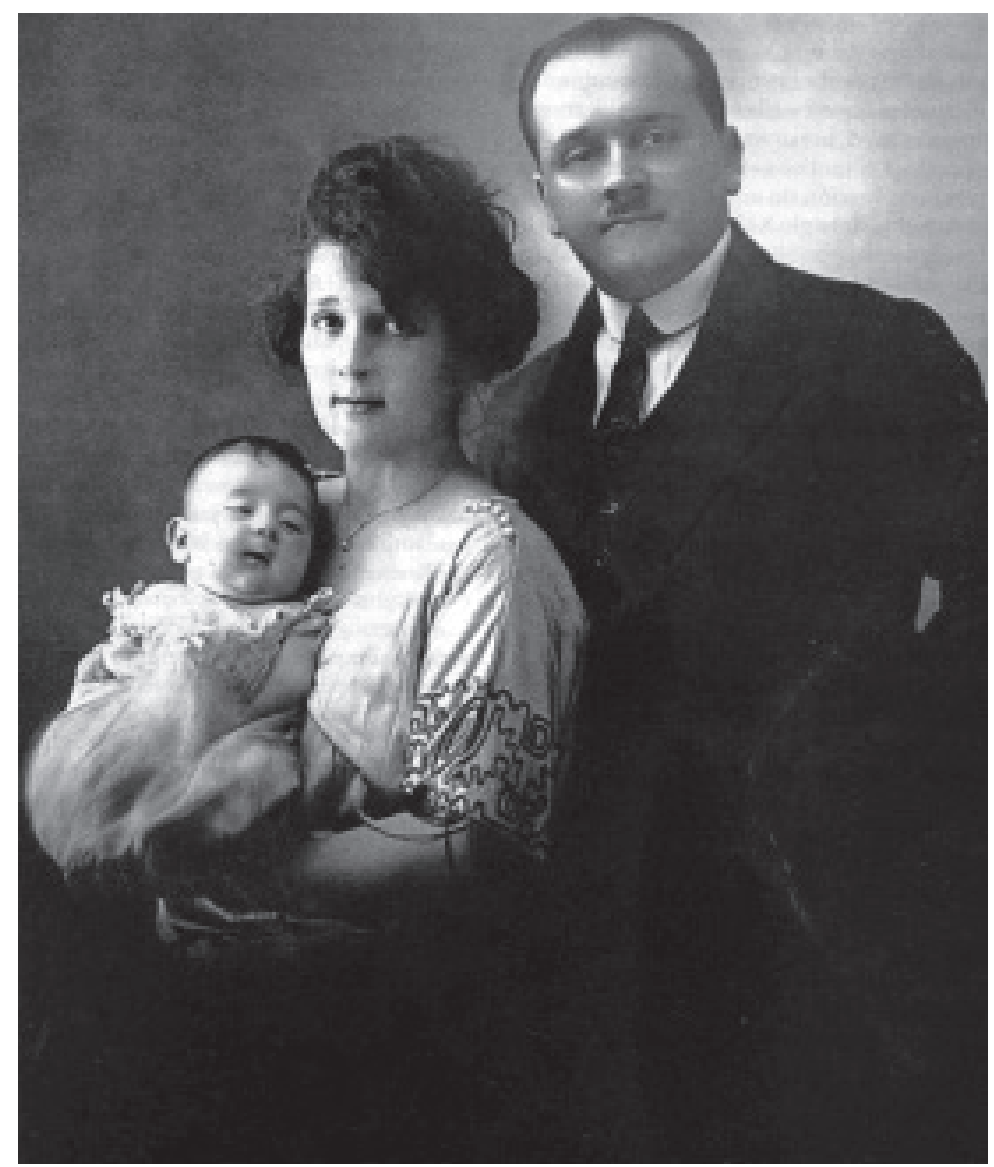

Fotografía tomada de la Revista Universidad de Antioquia p. 53

En la fotografía aparece Pedro Gómez Valderrama en manos de su madre Lucía Valderrama de Gómez acompañada de su padre 


\section{Conclusión}

(...) Imaginé también una obra platónica, hereditaria, transmitida de padre a hijo, en la que cada nuevo individuo

agregara un capítulo de los mayores.

Borges, J.L

El jardin de senderos que se bifurcan

Bien, después de haber andado por los caminos que recorren el trasfondo de la novela de Pedro Gómez Valderrama, haber consultado los géneros con los cuales coquetea y que lo llevan, de una u otra manera, conforme a su intención ideológica a escoger uno, es momento de llevar esta indagación a buen término. Para poder hacerlo baste un breve recuento que arroja luz sobre lo ya realizado. Nos hemos propuesto mostrar como en la única novela de Pedro Gómez Valderrama, La otra raya del tigre, hay un peculiar llamado a la formación de una conciencia histórica a partir de un diálogo de tradiciones. Es así que, para poder satisfacer dicho propósito hemos aclarado ya previamente el significado de los términos diálogo de tradiciones y conciencia histórica (Cfr. Infra Introducción). El primero de ellos asumido como el enlace de dos entes esencialmente diferentes que se dan al respetuoso juego de la comunicación; el segundo, el término conciencia histórica, entendido como una explicación argumentada de aquello que nos es fundamentalmente propio. Así mismo, siendo que la novela en mención recoge una problemática en su clasificación genérica hemos ofrecido un vagabundeo por el esclarecimiento de los géneros de novela histórica (Cfr. Cap. I) y nueva novela histórica (Cfr. Cap. II) respectivamente.

Por lo que respecta a la clasificación de estos géneros literarios baste recordar un par de cosas. Cada uno de ellos, tanto el de novela histórica como el de nueva novela histórica fue rastreado en base a algunos escritores y críticos literarios que se han detenido a meditar sobre ellos desde sus inicios como género y, así mismo, se señalaron algunas obras emblemáticas y escritores que tomaron parte de dicho género. También cada uno de estos géneros fue analizado en su relación con la verdad de hecho y el objeto que persiguen en sus narraciones con miras a forjarnos los respectivos "conceptos" de novela histórica y nueva novela histórica. Vimos entonces que la novela histórica goza de una breve ficcionalidad en la 
reconstrucción del hecho histórico y su fin último es reconstruir el espíritu de una época determinada. De otro lado pudimos observar que la nueva novela histórica en su relación con la verdad de hecho es un poco más laxa, podríamos indicar que ni siquiera le importa una reconstrucción aproximativa de la época al partir, como opina Aínza, del supuesto de que la historia miente (Cfr. 1991; 84); empero, pese a partir de este presupuesto la nueva novela histórica se sirve del saber proporcionado por la historia como telón de fondo sobre el cual actúa el relato ficcional. Por lo que corresponde a su objeto, es decir, al fin que persigue, es claro que en este tipo de relatos hay una evasión del pasado, del relató histórico oficial, y en consonancia con ello, procura una ficcionalidad posible de aquello que hubiese podido ocurrir alterno a la realidad histórica.

Posteriormente a este rodeo por los géneros literarios ya mencionados, se procuró hacer una presentación de algunos apartes relativos a la obra de Valderrama usando, así mismo, el método hermenéutico. Ello hizo posible que tuviéramos una perspectiva mucho más general de nuestro "objeto" de estudio y poder, así, caracterizar su novela La otra raya del tigre en relación al resto de su trabajo escrito. Allí, en dicho apartado se discute el género de la obra y se toma partido con algunos argumentos a favor de que la reflexión literaria de Valderrama es una novela histórica y no una nueva novela histórica señalando, igualmente, el porqué de la selección de dicho género.

Una vez hecho este recorrido, que puede para algunos significar un rodeo inútil, nos hemos detenido en la forma en como se lleva a cabo ese diálogo de tradiciones al interior de La otra raya del tigre mostrando las partes que conforman ese diálogo y valiéndonos para su análisis de una variación del método que usa la psicocrítica en relación a las obras literarias. Así es que hemos dedicado un capítulo para detenernos en la peculiar configuración psicológica del personaje Juan de Dios como un indicio de lo propio y, en un aparte diferente dentro del mismo capítulo nos hemos detenido en la de ese otro personaje, casi mítico, como lo es Geo von Lengerke, emblema de la cultura occidental. Ambos se constituyen como fuertes indicios de las dos tradiciones que entablan un diálogo en la novela ya citada. Cada uno de estos personajes posee una perspectiva de mundo que le es propia pero que, podríamos decirlo, no es cerrada a la mirada del otro. Así el abuelo que, previamente a conocer a Lengerke ha entrado en un diálogo con la tradición europea a través del arduo ejercicio de la autodidaxia se muestra, a diferencia de Lengerke, como un hombre poco voluptuoso pero afanado por el contacto con nuevas ideas sin caer por ello en un vano esnobismo; cabe anotar que dicha actitud sólo se ve reflejada en el ámbito del conocimiento y no del sentimiento moral, puesto que, como ya hemos visto, Juan de Dios no comparte ciertos comportamientos sexuales de Lengerke que se amparan en la consigna de un pensamiento liberal. 
Mientras tanto Lengerke, el Príncipe, sirve como un buen indicio de lo que ha sido el Viejo Mundo para los habitantes de una Colombia en formación. Portador de ideas liberales, espectro de su cosmovisión, Lengerke forma la noción de empresa y abre vías para que el comercio tenga lugar. Ello lo hace, como es claro en el texto de Valderrama, sin perseguir un beneficio común sino buscando el provecho propio (cfr. Valderrama, 2003; 101). Lengerke, más allá de la simple colonización de caminos es el icono de una nueva forma de concebir el mundo: instaura una nueva moral en donde la libido, en conjunto con una serie de libertades individuales hace gala.

De esta suerte, como lo hemos venido señalando, el texto de Gómez Valderrama constituye, a partir de ese diálogo de tradiciones cifrado en las cosmovisiones de los personajes anotados pero también en la selección del género literario, un peculiar llamado a la formación de una conciencia histórica. Este llamado no se hace de manera exclusiva tomando los contenidos que el mismo texto cifra al hacer referencia a hechos ya datados por la historia de una manera exageradamente rigurosa, cualidad que, por lo demás, no se conduele con la concepción que aquí, en el aparte respectivo de esta indagación (cfr. Supra; Cap. I), se ha dado de tal género y su vinculación con la verdad de hecho. El género escogido por Valderrama, la novela histórica a despecho de la nueva novela histórica -o lo que en la narración breve puede ser aparejado al Cosmopolitismo o al Boom- para ejecutar una empresa que lejos de ser "individual", como lo es la tarea de todo escritor, retoma el legado familiar que trae consigo una serie de compromisos con los contenidos de la escritura de los cuales anteriormente hemos anotado algunos. Por ahora baste decir que así, de esta manera, al irse hacia atrás en la reconstrucción de lo que ha sido el siglo XIX sin haber limitado el foco de su narración a una descripción de las cuestiones meramente regionales o extranjeras Valderrama teje su relato. Bien hubiese podido, si fuese su intención, construir un discurso autóctono, escoger para la narración de su novela el personaje de Juan de Dios o, en su defecto, Geo von Lengerke y así, de tal forma, ejecutar una narración en una sola voz y hacerlo mediante un género, en propiedad, latinoamericano como lo es la nueva novela histórica; no obstante Pedro Gómez no lo hace de esta manera y contrario a ello implica a los dos personajes en un diálogo que pone en comunión la cultura europea con la nuestra a través de ese punto en común que resulta ser la idea de libertad con un claro sesgo liberal (libertad de empresa, credo y, con ello, moral). Pedro Gómez procura así la reconstrucción de la memoria, un pasado abierto a la mirada del extranjero narrada fundamental pero no exclusivamente a partir de la focalización de Juan de Dios, el abuelo del escritor.

Así, como lo hemos anotado, el diálogo de tradiciones se muestra en la obra a partir de la comunicación que entabla Juan de Dios con Lengerke y de la memoria que de este, Lengerke, pervive en la memoria de aquel. Es en ese monstruo de vapor 
que surca el Río Grande del Magdalena, que puede ser leído también como indicio de ese río en el que Heráclito entrevió la ruina del hombre, es que se teje inicial y no gratuitamente esa comunicación del Nuevo Mundo con el Antiguo Continente sin caer en un discurso americanista, egocéntrico, nacionalista, exclusivo. De tal manera parece entenderlo Hernán Darío Restrepo al afirmar que "en esta novela, el Río Grande del Magdalena se erige como el espacio simbólico fundamental de los encuentros y desencuentros de las culturas en tránsito con el Nuevo Mundo" (1999; p. 92). Empero habría que recalcar que no sólo es a través de los contenidos depositados en la obra, como bien lo señala en este lugar la aparición del camino fluvial, sino, lo que es más sutil aún, en la selección del género literario al tomar para su elaboración una forma narrativa que apela a las ideas de progreso, que toma un personaje histórico para ejecutar su narración, una narración que se reconstruye tomando como base y fin último el pasado recurriendo a estrategias procedimentales como lo son las cartas, los caminos, los encuentros que se dan en ellos, la figura del castillo, los testimonios o el saber depositado en la oralidad de su familia que aparece desde la presentación misma del texto (Cfr. Valderrama, 2003; p. 7-8) como se le da vía la conjunto de elementos que configuran este diálogo de tradiciones. Todo este conjunto de indicios nos conducen a pensar que Valderrama labra en medio de ese juego entre la materia, es decir, los contenidos de la historia colombiana en la Santander del siglo XIX, y la forma, haber tomado la novela histórica con todas sus peculiaridades para realizar tal narración, la formulación de una consigna clave en el pensamiento liberal, la formación de una conciencia histórica, un postulado que no se podría sino condoler con un género literario $y$, al tiempo, con un buscador insaciable de la libertad del hombre, con un ser humano que, en palabras de su propio hijo, Pedro Alejo, sólo podría asesinarlo el tamaño de su corazón.

A la memoria de Pedro Gómez Valderrama

Universidad Tecnológica de Pereira Maestría en Literatura 


\section{Bibliografía}

\section{De Pedro Gómez Valderrama:}

-Gómez Valderrama, Pedro (1971). Los Ojos del Burgués. Ed. Educo. Bogotá.

----- (2002). La otra raya del Tigre. Ed. El tiempo, Bogotá.

----- (1977). La otra raya del Tigre. Ed. Siglo Veintiuno. Colombia.

----- (1984). La nave de los locos. Ed Alianza. Madrid.

----- (1959). Nosotros y la libertad. Ed. Iris. Bogotá.

----- (1973). La procesión de los ardientes (sin nota sobre la editorial) Bogotá.

\section{Sobre Pedro Gómez Valderrama:}

- $\quad$ Aristizabal, Alonso (1992). Pedro Gómez Valderrama. Ed. Procultura. Bogotá.

- Correa Díaz, Luís (2003). Una historia apócrifa de América. El arte de la conjetura en Pedro Gómez Valderrama.

- $\quad$ Gonzáles Martínez S. (1994). La imaginación liberal: hipótesis para una lectura de "La otra raya del tigre". Instituto Caro y Cuervo. Bogotá

Cuervo. Bogotá.

Ruiz, Jorge Eliécer (1995). Antología de Pedro Gómez Valderrama. Ed. Instituto Caro y

\section{Diccionarios:}

- Blanquez Fraile, Agustín (1966). Diccionario Latín Español. Ramón Sopena, España.

- Pabón S. de Urbina José (1944). Diccionario Griego-Español (2a Ed.). Barcelona: Spes.

-Sebastián Yarza, Florencio Isidoro (1945). Diccionario Griego- Español. Barcelona: Ramón Sopena.

\section{Lecturas complementarias:}

- Agustín, San (1940). La ciudad de Dios. Ed. Poblet, Buenos Aires.

- Bello, Andrés (1984). Gramática de la lengua castellana. Ed. Edad, Madrid.

- Borges, Jorge Luis (1980). Nueva antología personal, Poema a Heráclito, Ed. Club Bruguera, Buenos aires.

-Caicedo, Daniel (1954). Viento seco, Ed. Nuestra América, Buenos Aires.

- De Ruggiero, Guido (1944). Historia del liberalismo europeo. Ed. Pegaso, Madrid.

- Fernández Lelio, Gagin François, Papacchini Angelo, Romero A. Rodrigo, Urquijo Angarita Martín Johani, Rodas Cortés Francisco, Grueso delfín Ignacio y Valencia Gutiérrez, (2002). Obras clásicas del pensamiento político. Santiago de Cali, Universidad del Valle. 
-Gadamer, Hans-Georg (1993). El problema de la conciencia histórica. Ed. Tecnos. Madrid.

-Guido de, Ruggiero (1994). Historia del liberalismo europeo. Ed. Pegaso, Madrid

-Heidegger, Martin (2001). Caminos de Bosque. Ed. Alianza Editorial, España.

- Hobbes, Thomas (2002). De cive, elementos filosóficos sobre el ciudadano. Ed. Alianza, Madrid. (1935). Leviathan. Cambridge, at the University Press. Great Britain.

-Hume, David (2002). Investigación sobre el conocimiento humano Ed. Biblioteca Nueva, Madrid.

-Jardín, André (1985). Historia del liberalismo político, De la crisis del absolutismo a la constitución de 1875. Ed. Fondo de cultura económica, México

- Jaspers, Karl (1978). ¿Qué es la filosofía de la existencia? Ed. F.C.E. México.

-Kant, Immanuel (1998). Crítica de la razón pura. Ed. Alfaguara, Bogotá.

(1943). Principios metafísicos del derecho. Ed. Americalee, Buenos Aires.

(1981). Filosofía de la historia. Ed. Fondo de cultura económica, México.

Locke, John (1998). Ensayos sobre la ley natural. Ed. Laxes, España.

(1941). Ensayo sobre el gobierno civil. Ed. F.C.E. México.

-Osorio Lizarazo J.A. (1998). El día del odio, Ancora editores, Bogotá Colombia.

-Rincón, Carlos y Serna Arango, Julián (2008). La palabra como provocación. Magia, versos y filosofemas. Ed. Antropos, Madrid.

- Rousseau, Jean Jaques (1987). Discurso sobre el origen y los fundamentos de la desigualdad entre los hombres Ed. Rei, Bogotá.

(1993). El contrato social. Ed. Altaya, Madrid

-Sartre, Jean Paul (1966). El ser y la nada. Ed. Losada, Buenos Aires.

-Silva, José Asunción (1998). Poesía completa. Ed. Educar. Colombia.

- Stendhal, Henry (1953). Del amor. Buenos Aires, Ed. Tor.1953.

-Vasconcelos, José (1999). La raza cósmica. Ed. Centro de estudios generales universidad Nacional. Costa Rica

- Zapata, García Carlos y César muños Arroyave (1993). Lecciones de morfología española. Universidad de Antioquia; Medellín.

- Zuleta Estanislao (2001). Elogio de la dificultad y otros ensayos. Cali, Ed. Fundación Estanislao Zuleta. 


\section{Libros de Crítica Literaria:}

- Abad Torres, Alfredo (2007). Filosofía y literatura, encrucijadas actuales Universidad Tecnológica de Pereira.

- Abad Alfredo Andrés (2008). Pensar lo implícito. En torno a Gómez Dávila. Ed. Postergraf, Pereira.

- Amado Alonso (1942). Ensayo sobre la novela histórica, Buenos Aires, Instituto de Filología.

-Bajtín, Mijaíl (1991). Teoría y estética de la novela, España, Ed. Taurus.

- Cabrales Rodolfo (2008). Porchia: el íntimo desvarío de la certeza. Ed. Universidad Tecnológica de Pereira.

- García Gual, Carlos (1972). Los orígenes de la novela, Madrid, ediciones ISTMO.

- Fernández Prieto, Celia. (1998). Historia y novela: Poética de la novela histórica. Ediciones Universales de Navarra. Pamplona.

- Elmore, Peter (1997). La fábrica de la memoria. Lima, Ed. Fondo de Cultura Económica.

-Espinosa, Germán (2002). Ensayos completos. Tomos I y II. Ed. Eafit. Medellín.

----- (2000). Espinosa oral. Editorial Fondo de Publicaciones de la Universidad del Atlántico, Colombia.

- Giraldo Naranjo, Julián Alberto (2006). Ser y acontecer del nuevo mundo. Ed. Universidad Tecnológica de Pereira, Pereira.

- Maurón, Charles (1997). Psicocrítica del género cómico. Ed. Arco Libros, Madrid.

-Menton, Seymour (1993). La nueva novela histórica de la América Latina. Fondo de Cultura Económica, México.

------- (1978). La novela colombiana, planetas y satélites. Editorial Andes, Colombia.

(1970). El cuento hispanoamericano

- Lukács, George (1971). La novela histórica, México, Biblioteca Era.

-Solanilla Valencia, César (2008). De la periferia al centro, la novela finisecular del Eje Cafetero. Fondo Editorial de Risaralda, Colombia.

\section{Libros sobre psicología:}

- Jaspers, Karl (1967). Psicología de las concepciones de mundo. Ed. Gredos, Madrid.

(2001). Psicopatología general. Ed. F.C.E. México.

-Jung, Carlos Gustavo (1972). Teoría del Psicoanálisis. Ed. Plaza \& Janés. Barcelona.

------ (2006). La práctica de la psicoterapia. Ed. Trotta, Madrid.

-----(1986). Los complejos y el inconsciente. Ed. Círculo de lectores, Bogotá. 


\section{Novelas Históricas:}

-Alejandro Dumas (1978) Los tres mosqueteros. Barcelona. Ed. Bruguera

-Stendhal (1993). Rojo y Negro, Bogotá, ed. Oveja Negra. II Tomos

(1975). La Cartuja de Parma, Ed. Bedout S. A. Medellín.

(1969). Armancia. Ed. Ciencia Nueva, Madrid.

\section{Nuevas novelas históricas:}

- Espinosa, Germán (1982). La tejedora de coronas. Ed. Alianza. Colombia.

- Piglia, Ricardo (1993). Respiración artificial. Tercer mundo editores. Bogotá.

\section{Revistas y publicaciones seriadas:}

- Aínza, Fernando (1991; Septiembre). La nueva novela histórica latinoamericana, en Plural, Revista cultural, Pp. 82-85

- $\quad$ Aristizabal Alonso (2006; Abril Junio). Contrahistoria viva de Pedro Gómez Valderrama. Universidad de Antioquia. Dossier Pedro Gómez Valderrama. Pp. 78-83.

- $\quad$------ (Ibíd). Gómez Valderrama viajero de la vida y el universo de la imaginación. pp 84-91.

- Campuzano Montoya Pablo (2006, Abril Junio). Variaciones en torno a Pedro Gómez Valderrama. Universidad de Antioquia. Dossier Pedro Gómez Valderrama. pp. 46-57.

- $\quad$ Correa Díaz Luis (1994; Enero-Abril). El grito colombino de “iTierra!” en el relato de Pedro Gómez Valderrama; THESAVRVS. Instituto Caro y Cuervo.

- García Londoño Andrés (2006, Abril Junio). Sensualidad y libertad en Pedro Gómez Valderrama; Universidad de Antioquia. Dossier Pedro Gómez Valderrama. pp. 92-101.

- $\quad$ Girado Alexander (2006, Abril Junio). De las versiones apócrifas de la historia a la historia como invención Universidad de Antioquia. Dossier Pedro Gómez Valderrama. pp. 58-66.

- Gómez Vila Pedro Alejo (1994; Mayo 15). El tamaño de su corazón. En Dominicales, periódico El Tiempo. Bogotá. p. 13.

- $\quad$ Henao Restrepo, Darío (1999; julio-Diciembre). Gómez Valderrama o la utopía liberal. En Estudios de literatura colombiana, Universidad de Antioquia. pp. 90-98. pp. $45-52$.

Pineda Botero, Álvaro (1995; Agosto) Bolívar y la nueva novela histórica. En Gaceta No. 29

Restrepo David Juan F. (2006, Abril Junio). Los viajes de Pedro Gómez Valderrama; Universidad de Antioquia. Dossier Pedro Gómez Valderrama. Pp. 106-111. Bogotá. p. 100.

Suescún, Nicolás (1996; Noviembre). Las alas de Pedro Gómez Valderrama. Revista Diners,

Taborda Sánchez Juan Fernando (2006, Abril Junio). Historia y brujería en los cuentos de Pedro Gómez Valderrama Universidad de Antioquia. Dossier Pedro Gómez Valderrama. pp. 67-77. 


\section{Publicaciones virtuales:}

* www.arquitrave.com/periodico/periodico_casa_silva.html Septiembre 26/2008.

${ }^{*}$ http://fis.unab.edu.co/docentes/olengerke/geovonlengerke/ Septiembre 26/2008.

${ }^{*}$ www.revistadiners.com.co/noticiaphp3?nt=25450; Dic 7/2007. 


\section{Índice Onomástico}

Abad Torres, Alfredo: 10, 30, 60, 69, 70

Agustín, San: 31; 76

Aínza, Fernando:21; 50;51;52

Amado, Alonso:21;32;35-60

Arciniegas, Germán: 34

Aristizabal, Alonso: 60; 62; 65.

Arreola, Juan José: 68

Balzac, Honorato: 22;26;38

Bajtín, Mijaíl: 7;9;19;25;29;43;45-49;50;56;77;80;81

Becaria, César: 61

Beethoven, Ludwig van: $61 ; 91$

Bello, Andrés: 15;68;71,85

Boccaccio, Juan: 28

Bolívar, Simón: 61;73

Borges, Jorge Luis: 16;56;73

Bosco, Jerónimo: 72;74

Cabrales, Rodolfo: 10

Campuzano Montoya, Pablo: 60

Carlomagno: 74

Carrasquilla, Tomás: 13

Cervantes, Miguel de: 28; 61,68,70

Chrétien de Troyes:28

Crusoe, Robinson: 69

Colón, Cristóbal: 73

Correa Díaz, Luis: 60;69,70

Dostoievsky, Fedor: 61

Dumas, Alejandro: 22;34,35;37;61;88

Echaurí Martínez Eustaquio: 31

Eco, Umberto:56

Elmore, Peter: 13;16;21

Espinosa, Germán: 21;35;53;60,61;81

Flaubert, Gustavo: 36

Foucault, Michel: 54

Fraile Blanquez José Pabón: 19

Freud, Sigmund: 71,81,92

Gadamer, Hans Georg: 17;19

García, Londoño Andrés: 28,29,30

García Gual, Carlos: 60,70

Giraldo, Alexander: 61,73,91

Goethe, Johann Wolfgang: 72; 105; 107

Gómez Vila Pedro Alejo: 60

Jaspers, Karl: 11;44; 71,76;80,81,83

Heidegger, Martín: 15;54

Henao Restrepo, Álvaro: 89

Heráclito de Éfeso: 16;97

Heródoto: 31

Hoffman, Ernesto Teodoro Amadeo: 91

Humboldt von, Carlos Guillermo: 92

Hume, David: 31,32.

Husserl, Edmund: 54

Kant, Emmanuel: 16;31;50;61;73,74;88
Lengerke, Geo von:20,21;63,66;67,78,80,81,84-87,89-

93,95-97

Levi-Strauss, Claude: 54

Lukács George: 20-22,26-27,36-40,43-44

Marco Polo: 61

Martínez González Serafín: 60

Márquez, García Gabriel: 50,60

Maurón, Charles: 80-82

Menton, Seymour: 13,21-22,48-49,51-52,55-57,60-61,68

Montaigne, Michel de: 53

Monterroso, Augusto: 68

Mozart, Wolfgang Amadeus: 61,91

Mutis, Álvaro: 68

Osorio, Lizarazo Juan: 64

Pabón S. de Urbina José: 31

Paganini, Nicolo: 61,73

Pascal, Blase: 53

Paso, Fernando del:55

Peers, Apull Allison: 42

Pessoa, Fernando: 57

Pietri, Arturo Uslar: 68

Piglia, Ricardo: 51,57

Pineda, Álvaro: 54

Platón: 61,73,89

Posse, Abel: 54

Prieto, Celia Fernández: 21,41-42,44

Restrepo, Hernán Darío: 60,68-69,97

Rousseau, Jean Jaques: 74,92

Ruíz, Jorge Eliecer: 4,33-34

Santander, Francisco de Paula: 61,71,87

Sade, Marqués de: 61,73

Sartre, Jean Paul:438,54

Schopenhauer, Arthur: 61,60-61,71

Schubert, Franz: 91

Scott, Walter: 22,35,37,40-41,43,45,60-61, 91

Silva, José Asunción:34,61,68-69,71-73

Stendhal, Henry Beyle:14,22,26,37, 61, 68-69, 71-73

Strauss, Levy : 54

Sue, Eugenio: 88,91

Suescún, Nicolás: 60

Taborda Sánchez, Juan Fernando:58,60

Valderrama, Pedro Gómez: 5-10,12;14,19-22,23-

34,37,48,58,60-77,80-97

Valencia Solanilla, César: 16,13,52,60

Valery, Paul: 54

Vasconcelos, José:17-19

Verne, Julio: 86,88

Wagner, Ricardo: 91

Yarza Florencio, Sebastián: 31

Ziller, Edmund: 56

Zuleta, Estanislao: 10 


\section{Îndice Analítico}

América: 14,19,52,53,60,61,69,73,92

Boom: 68,96

Carnavalesco:49,56-57

Carnavalización: 65

Concepción de mundo: 80-81,83-84,85,90

Conciencia: 7,9-12,14-18,20,32-33,44,48,52-53,82

Conciencia histórica: 7,9-12,17,20,44-45,53,68,94,96-97

Cosmovisión: 19,42,52,70,74-75,82-83,92-93,96

Cosmpolitismo: 53,68,96

Cronotopo: 45

Dialógico: 49-50,56-57

Dialogismo: 50

Diálogo: 7,9-11,17-21,51,53,67,70,80-81,87-88,93,94-97

Espíritu de época: 45,51-52

Europa:17,19,53,67,76,77.87,90

Fidelidad histórica: 41-42,44

Ficción:41,43,48,52,58,60,71

Ficcionalidad: 42,52-54,57,70-71,95

Forma de ver el mundo: 19,80

Hecho histórico: 35,41,43-44,95

Heteroglósico: 49-50

Historia: 9, 11, 16-19, 21-22, 25, 28, 30-41, 43-45, 48-49-, 51-52; 54-58, 60, 63-64, 66, 68, 69, 70, 72-76, 80, 88, 95, 96-97

Intertextualidad: 49-50,55-56,58

Idea de libertad: 83

Idea de progreso: 40,44,65,68,69,70,72-76,80,88,95,96-97

Latinoamérica: 72

Libertad: 60,61,64,69,75,77,80,85-86,91,92-93,96,97

Literatura: 5,7,9,10,13,21-22,25-26,34-38,44,53,55-

$56,57,60,63,68,72,74,80-81,88,97$

Metaficción: 49,51,56

Novela: 5,7-9,13,19-22,25-30,35,37-39,41,44,48-51,53,56-

$58,60-68,75,81,85,89,90,94-97$

Novela histórica: 9-10,21-22,25-27,30-31,34-40,42-

45,48,52-54,60,62,64-68,91,94-97

Nueva novela histórica: 9,21-22,25,42,48-57,60,62,64,66-

$67,69,94-96$
Occidente: $13,17-18,33,53,73,77,87,89$

Objeto de la novela: $36-37,40,48$

Pensamiento liberal: 62,64,66,68,74-

77,83,85,89,92,96-97

Plurilingüismo: 67

Progreso:40,44,63,65-66,85-86,88,97

Tiempo: 5,7-9,11-14,15-19,25,28-39,60,62,71,73-

$75,77,84-85,87,97$

Tradición: 11;20-25;29;65;72;81;94;96;98;100;

$104 ; 106 ; 114$

Verdad histórica: 39,41,52,54

Verdad de hecho: (En la novela histórica) 25,37,39-

41,43-44,48,52,54-55,57,94-96 (En la nueva novela histórica) 65

Vinculación con la verdad de hecho (En la Novela histórica): 56; (En la nueva novela histórica) 61;

64; 68

Visión de mundo: 63,74,82,85 


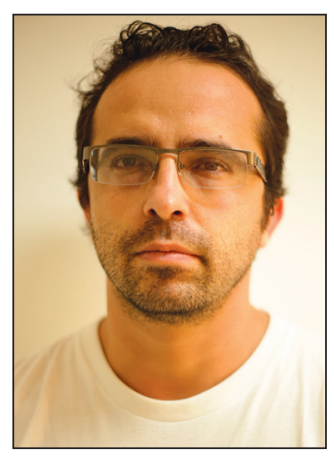

Juan Manuel López Rivera, (Pereira, Risaralda, Colombia, 1980). Magister en Literatura de la Universidad Tecnológica de Pereira.

Profesor Transitorio de la Escuela de Filosofía asociado a la Facultad de Bellas Artes y Humanidades.

Ha publicado artículos en revistas especializadas nacionales.

Pertenece al grupo de investigación Filosofía Antigua

jlmr@utp.edu.co

La Editorial de la Universidad Tecnológica de Pereira tiene como política la divulgación del saber científico, técnico y humanístico para fomentar la cultura escrita a través de libros y revistas científicas especializadas.

Las colecciones de este proyecto son: Trabajos de Investigación, Ensayo, Textos Académicos y Tesis Laureadas.

Este libro pertenece a la Colección Ensayos.

(c) Edición Digital.

e-book

Pereira, Risaralda, Colombia.

2017 
En principio hay que indicar que nuestro propósito inicial es mostrar cómo en la obra de Pedro Gómez Valderrama, La otra raya del Tigre hay una apelación a una conciencia histórica a partir de un diálogo de tradiciones. Este propósito necesita para ser llevado a su final, discernir separadamente aquello que se entiende tanto por conciencia histórica, como por la expresión diálogo de tradiciones (un proceso de definición de términos propio de la filosofía), aspecto que fue llevado a en la Introducción del texto.

Una vez definidos este par de términos, nos vimos precisados a señalar que tanto esa conciencia histórica, como ese diálogo de tradiciones se buscaban en una obra particular: $L a$ otra raya del tigre. Esta obra de nuestra literatura ha recibido sobre sí disímiles calificativos acerca del género que frecuenta, entre ellos encontramos la clasificación de novela histórica y nueva novela histórica, géneros literarios que fue necesario esclarecer respectivamente en los capítulos uno y dos.

Así, una vez esclarecidos los términos novela histórica y nueva novela histórica se llevó a cabo la presentación de la obra de Pedro Gómez Valderrama. Este sondeo general por sus Invenciones y artificios, sus Muestras del diablo, Los ojos del burgués, La nave de los locos, El retablo de maese Pedro y algunos otros textos del y sobre el autor contribuyeron a ubicar la novela de Pedro Gómez en ese género de novelas que hemos denominado en nuestro trabajo novela histórica; las demás narraciones, los cuentos o relatos cortos, pueden ser ubicados en esos dos otros géneros que a nuestro juicio, y esto es un atrevimiento, nutren la nueva novela histórica, el boom y el cosmopolitismo.

ISBN: 978-958-722-282-1 